ORNL/TM-2014/533

\title{
Initiating Events for Multi-Reactor Plant Sites
}

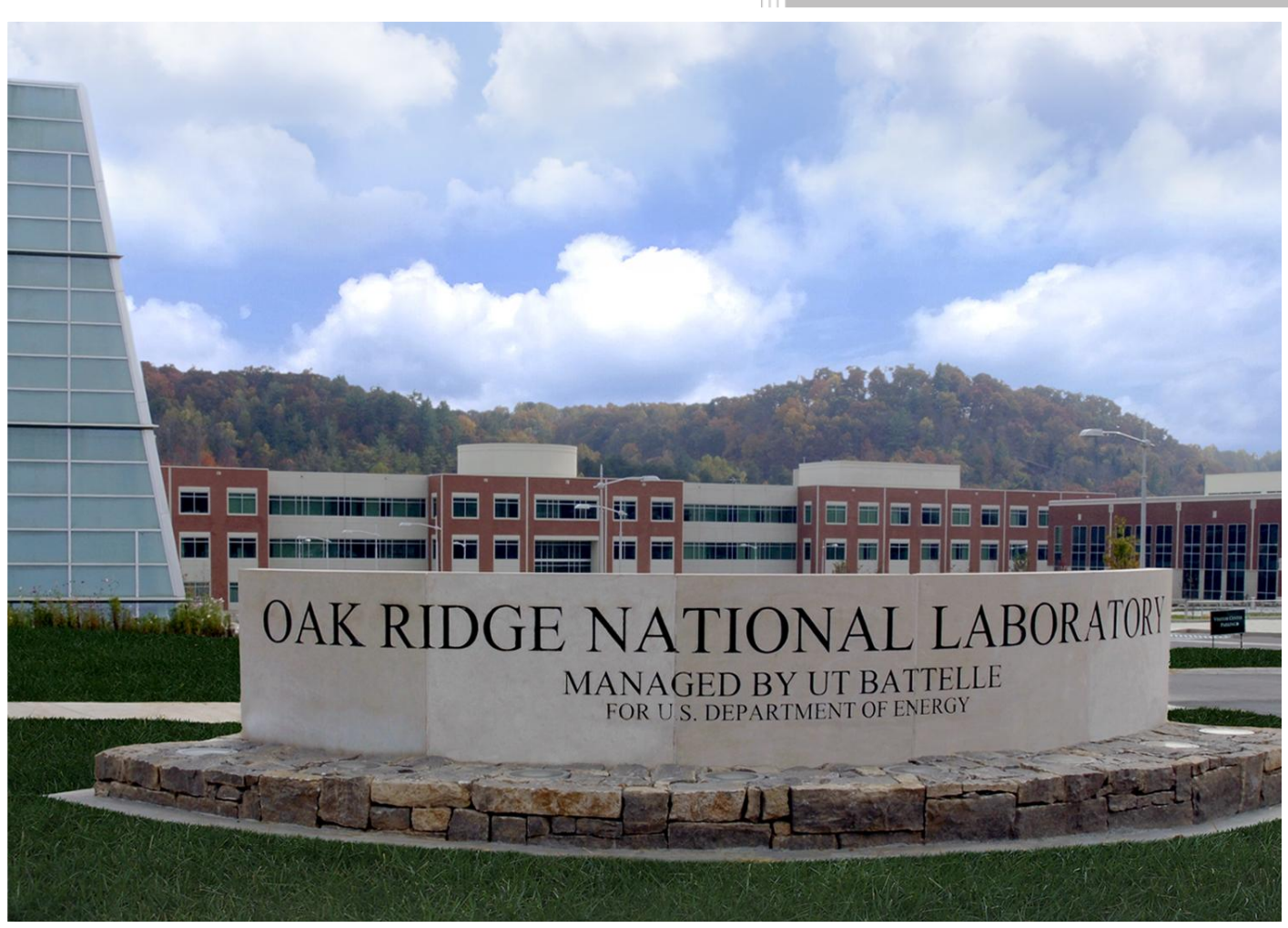

Approved for public release. Distribution is unlimited.
Michael D. Muhlheim George F. Flanagan Willis P. Poore, III

\section{September 2014}




\section{DOCUMENT AVAILABILITY}

Reports produced after January 1, 1996, are generally available free via US Department of Energy (DOE) SciTech Connect.

Website http://www.osti.gov/scitech/

Reports produced before January 1, 1996, may be purchased by members of the public from the following source:

National Technical Information Service

5285 Port Royal Road

Springfield, VA 22161

Telephone 703-605-6000 (1-800-553-6847)

TDD 703-487-4639

Fax 703-605-6900

E-mail info@ntis.gov

Website http://www.ntis.gov/help/ordermethods.aspx

Reports are available to DOE employees, DOE contractors, Energy Technology Data Exchange representatives, and International Nuclear Information System representatives from the following source:

Office of Scientific and Technical Information

PO Box 62

Oak Ridge, TN 37831

Telephone 865-576-8401

Fax 865-576-5728

E-mail reports@osti.gov

Website http://www.osti.gov/contact.html

This report was prepared as an account of work sponsored by an agency of the United States Government. Neither the United States Government nor any agency thereof, nor any of their employees, makes any warranty, express or implied, or assumes any legal liability or responsibility for the accuracy, completeness, or usefulness of any information, apparatus, product, or process disclosed, or represents that its use would not infringe privately owned rights. Reference herein to any specific commercial product, process, or service by trade name, trademark, manufacturer, or otherwise, does not necessarily constitute or imply its endorsement, recommendation, or favoring by the United States Government or any agency thereof. The views and opinions of authors expressed herein do not necessarily state or reflect those of the United States Government or any agency thereof. 
Reactor and Nuclear Systems Division

\title{
INITIATING EVENTS FOR MULTI-REACTOR PLANT SITES
}

\author{
Michael D. Muhlheim \\ George F. Flanagan \\ Willis P. Poore, III
}

Date Published: September 2014

\author{
Prepared by \\ OAK RIDGE NATIONAL LABORATORY \\ Oak Ridge, Tennessee 37831-6283 \\ managed by \\ UT-BATTELLE, LLC \\ for the \\ US DEPARTMENT OF ENERGY \\ under contract DE-AC05-00OR22725
}





\section{CONTENTS}

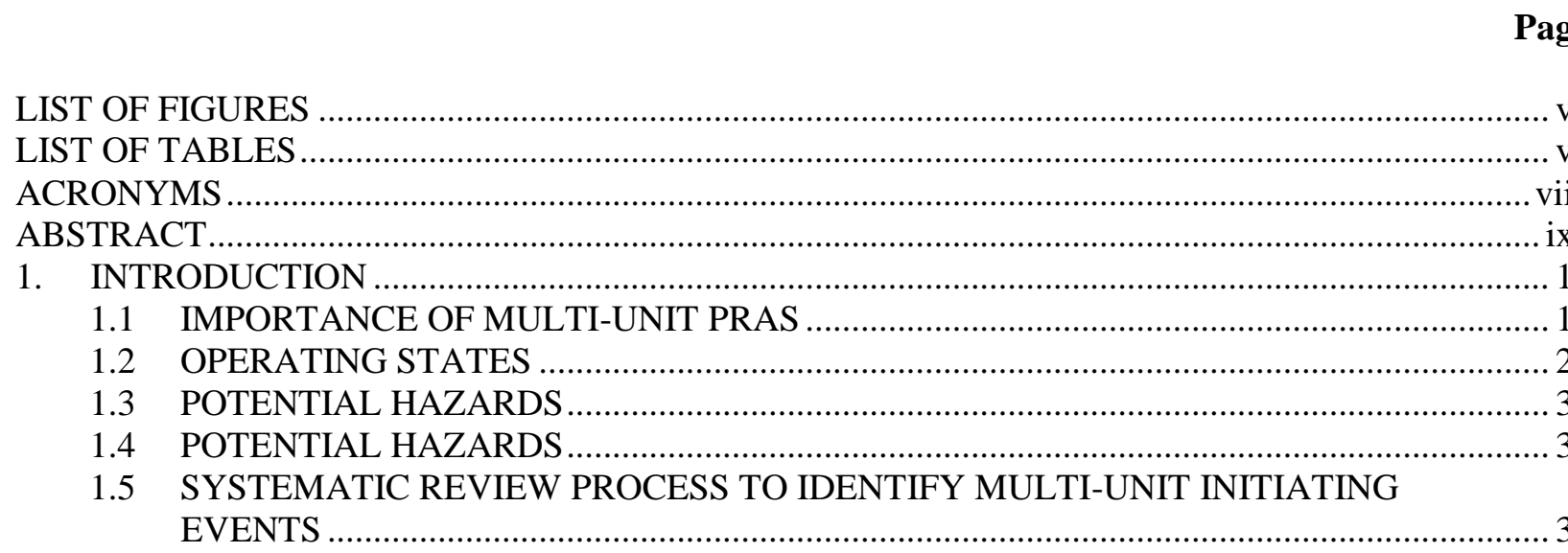

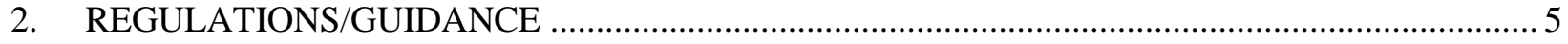

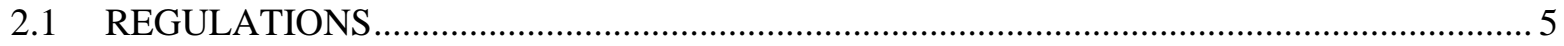

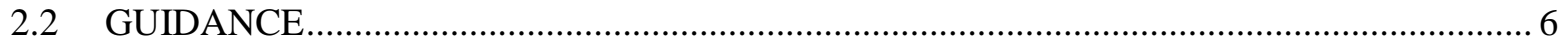

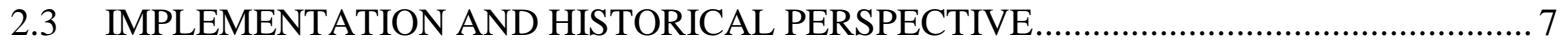

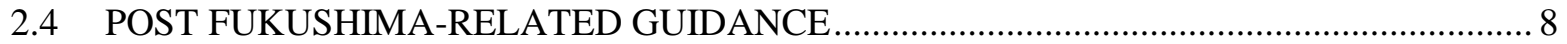

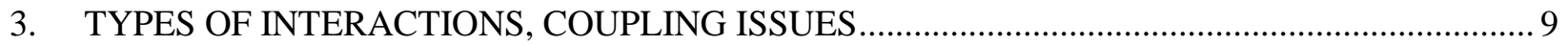

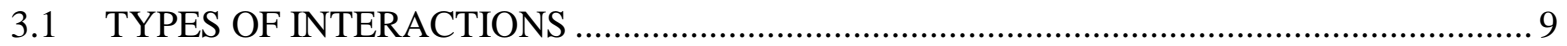

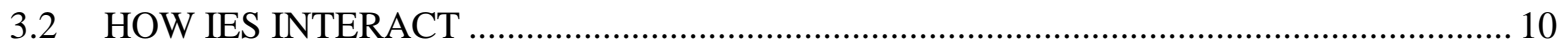

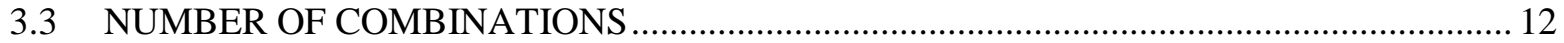

4. PROBABILISTIC RISK ASSESSMENTS AND INDIVIDUAL PLANT EXAMINATIONS ......... 13

4.1 PROBABILISTIC RISK ASSESSMENTS AND INDIVIDUAL PLANT

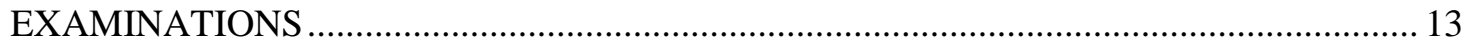

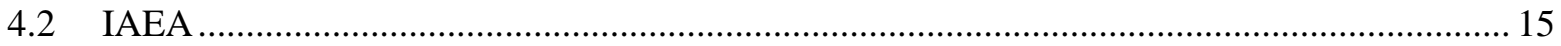

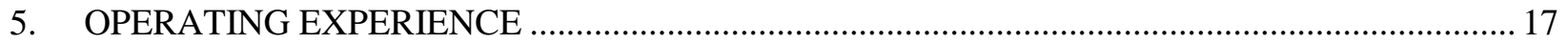

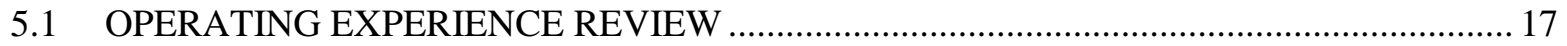

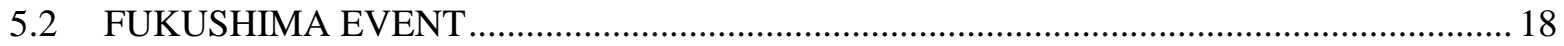

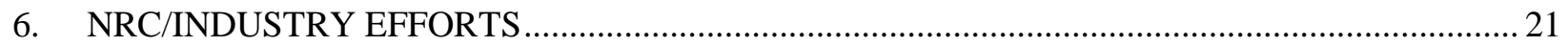

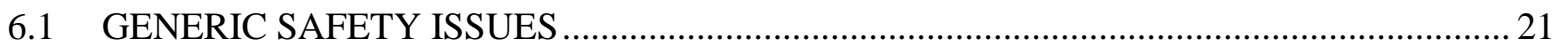

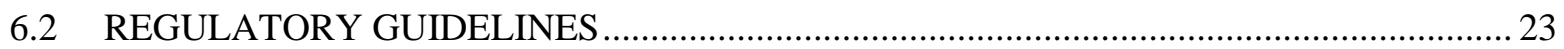

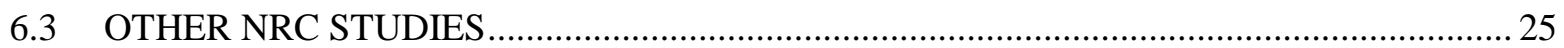

6.4 INTERNATIONAL STUDIES RELATED TO MULTI-UNIT IES ..................................... 26

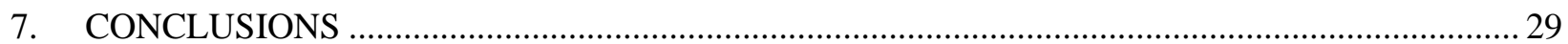

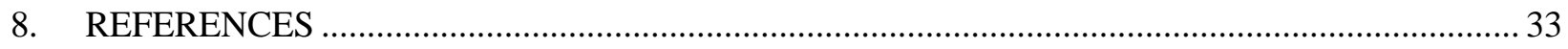

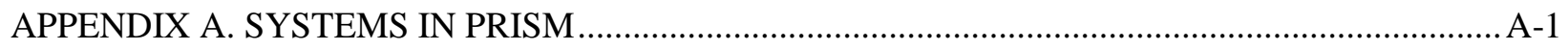

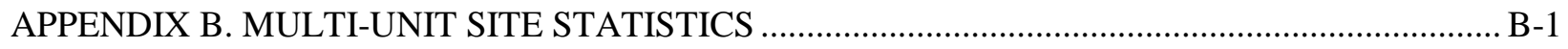

APPENDIX C. OPERATING EXPERIENCE REVIEW FOR MULTI-UNIT INITIATING

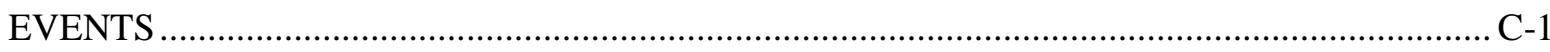

APPENDIX D. SINGLE- AND DUAL-UNIT INITIATING EVENTS …........................................ D-1

APPENDIX E. GENERIC SAFETY ISSUES WITH MULTI-UNIT IMPLICATIONS ........................ E-1

APPENDIX F. REGULATORY GUIDES WITH MULTI-UNIT IMPLICATIONS …............................ -1

APPENDIX G. OTHER NRC STUDIES WITH MULTI-UNIT IMPLICATIONS ............................... G-1

APPENDIX H. INTERNATIONAL STUDIES RELATED TO MULTI-UNIT INITIATING

EVENTS 


\section{LIST OF FIGURES}

Figure

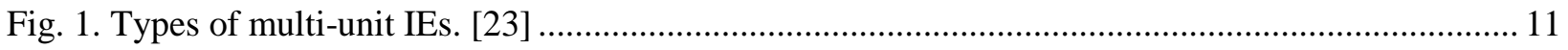

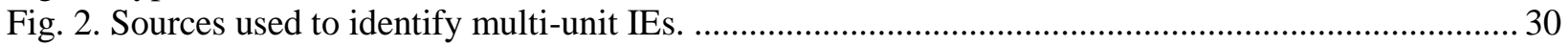

\section{LIST OF TABLES}

Table

Table 1. Types of interactions between units at a multi-unit site ...................................................... 9

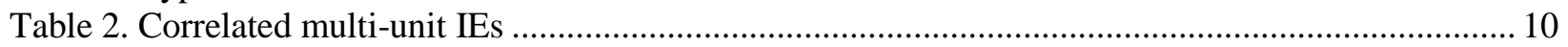

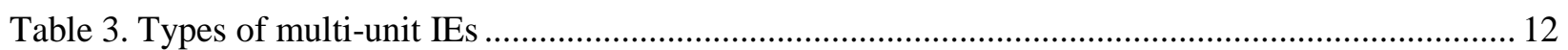

Table 4. Transmission system faults that involved multiple reactor trips.............................................. 19

Table 5. Summary of dual unit reactor trips based on all operating experience from 1987-1995

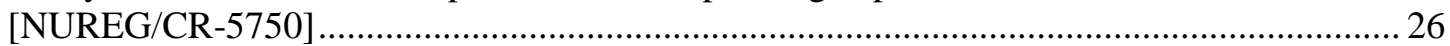

Table 6. Preliminary list of multi-unit IEs in single- or multi-unit PRAs............................................... 31 



\section{ACRONYMS}

\begin{tabular}{|c|c|}
\hline AACDG & $\begin{array}{l}\text { alternate ac diesel generator } \\
\text { alternating current }\end{array}$ \\
\hline ACRS & Advisory Committee on Reactor Safeguards \\
\hline AdvSMR & advanced small modular reactor \\
\hline AEOD & Office for Analysis and Evaluation of Operational Data \\
\hline ANO & Arkansas Nuclear One \\
\hline ANS & American Nuclear Society \\
\hline ASME & American Society of Mechanical Engineers \\
\hline BVPS & Beaver Valley Power Station \\
\hline $\mathrm{CCF}$ & common-cause failure \\
\hline CCI & common-cause initiators \\
\hline $\mathrm{CCW}$ & component cooling water \\
\hline $\mathrm{CDF}$ & core damage frequency \\
\hline CFR & Code of Federal Regulations \\
\hline $\mathrm{COL}$ & combined operating license \\
\hline CPMA & conditional probability of a multiple core accident \\
\hline CREACUS & control room emergency air cleanup system \\
\hline CSNI & Committee on the Safety of Nuclear Installations (CSNI) \\
\hline CSST & common station service transformer \\
\hline DOE & US Department of Energy \\
\hline $\mathrm{dc}$ & direct current \\
\hline ECCS & emergency core cooling system \\
\hline EDG & emergency diesel generator \\
\hline EE-PSA & external event probabilistic safety analysis \\
\hline ESW & essential service water \\
\hline FSAR & final safety analysis report \\
\hline GDC & general design criterion \\
\hline GSI & generic safety issue \\
\hline HEPA & high efficiency particulate air \\
\hline HFE & human factors engineering \\
\hline HVAC & heating, ventilation, and air conditioning \\
\hline IAEA & International Atomic Energy Agency \\
\hline IAS & instrument air system \\
\hline IE & initiating event \\
\hline IEEE & Institute of Electrical and Electronics Engineers \\
\hline INL & Idaho National Laboratory \\
\hline IPE & individual plant examination \\
\hline IPEEE & individual plant examination external events \\
\hline ISSC-EBP & International Seismic Safety Centre's Extra Budgetary Programme \\
\hline IST & inservice testing \\
\hline LBE & licensing basis event \\
\hline LER & licensee event report \\
\hline LOCA & loss-of-coolant accident \\
\hline LOOP & loss of offsite power \\
\hline LOSP & lost offsite power \\
\hline LPSD & low power and shutdown \\
\hline LWR & light-water reactor \\
\hline MHTGR & Modular High-Temperature Gas-Cooled Reactor \\
\hline
\end{tabular}




$\begin{array}{ll}\text { MSRP } & \text { Multiple System Responses Program } \\ \text { NCO } & \text { Niigataken Chuetsu-oki } \\ \text { NEI } & \text { Nuclear Energy Institute } \\ \text { NGNP } & \text { next generation power plant } \\ \text { NPP } & \text { nuclear power plant } \\ \text { NRC } & \text { Nuclear Regulatory Commission } \\ \text { NRR } & \text { Office of Nuclear Reactor Regulation } \\ \text { ORNL } & \text { Oak Ridge National Laboratory } \\ \text { PCB } & \text { power circuit breaker } \\ \text { PBMR } & \text { Pebble Bed Modular Reactor } \\ \text { PRA } & \text { probabilistic risk assessment } \\ \text { PRISM } & \text { power reactor innovative small module } \\ \text { PSA } & \text { probabilistic safety assessment } \\ \text { RCP } & \text { reactor coolant pump } \\ \text { RG } & \text { regulatory guide } \\ \text { RPS } & \text { reactor protection system } \\ \text { RWST } & \text { refueling water storage tank } \\ \text { SBO } & \text { station blackout } \\ \text { SEP } & \text { systematic evaluation program } \\ \text { SSC } & \text { structures, systems, and components } \\ \text { SMA } & \text { seismic margin assessment } \\ \text { SMR } & \text { small modular reactor } \\ \text { SOARCA } & \text { State-of-the-Art Reactor Consequence Analyses } \\ \text { SFP } & \text { spent fuel pool } \\ \text { SPSA } & \text { seismic probabilistic safety assessment } \\ \text { SRM } & \text { safety requirements memorandum } \\ \text { SRP } & \text { standard review plan } \\ \text { SUI } & \text { single unit initiator } \\ \text { TGIS } & \text { toxic gas isolation system } \\ \text { TMI } & \text { Three Mile Island } \\ \text { TVA } & \text { Tennessee Valley Authority } \\ \text { UAT } & \text { unit auxiliary transformer } \\ \text { UHS } & \text { ultimate heat sink } \\ \text { UPS } & \text { uninterruptable power supply } \\ \text { USI } & \text { unresolved safety issue } \\ \text { VOPT } & \text { variable over power trip } \\ & \end{array}$




\begin{abstract}
Inherent in the design of modular reactors is the increased likelihood of events that initiate at a single reactor affecting another reactor. Because of the increased level of interactions between reactors, it is apparent that the Probabilistic Risk Assessments (PRAs) for modular reactor designs need to specifically address the increased interactions and dependencies.

A PRA measuring the risk associated with a single reactor unit will fail to identify and properly measure the risk of interactions between units. The first step in properly assessing the risk at multi-unit plant sites is to identify those events that have the potential to affect multiple units. Thus, the objective of this task in support of the Department of Energy's Office of Nuclear Energy Advanced Small Modular Reactor (AdvSMR) is to compile a preliminary list of multi-unit initiating events (IEs). IEs are used as starting points for identifying susceptibilities and for conducting PRAs and selecting a complete and representative set of IEs is one of the most important tasks for determining risk. The next step in assessing the risk at multi-unit sites (future work) is to select several of the multi-unit IEs to compare different approaches for evaluating the risks associated with the increased interactions and dependencies among multi-reactor plant sites.

This review first looked at several PRAs that evaluated the risks associated with multiple units at a site. Because the design philosophy at modular plants is to maximize the sharing of services and facilities, this review also looked at the PRAs of modular plants to identify multi-unit IEs. The benefits of these reviews were minimal because, although they evaluated multi-unit risks, the list of IEs was incomplete.

The modular design of AdvSMRs increases the likelihood that a single reactor unit's IE can affect another reactor. The increased sharing of systems and structures and the close proximity of units results in an increased level of direct and indirect interactions among the reactor units. Therefore, the PRAs for modular reactors need to specifically address the increased interactions and dependencies. Current assessments will continue to underestimate site risk and improperly identify risk drivers until (1) multiunit interactions are understood, (2) comprehensive lists of multi-unit IEs become available, and (3) guidance on modeling multi-unit accident scenarios become available.

Because the risks and risk drivers vary significantly for multi-unit sites compared to single-unit sites, and the limited insights provided in the review of existing multi-unit PRAs, the types of documents reviewed for insights into possible multi-unit interactions were expanded. That is, selecting potential multi-unit IEs the same as had been done previously would lead to an incomplete and misleading set of initiators. The following approach was used to identify types of multi-unit IEs:
\end{abstract}

- A list of the types of multi-unit IEs to be considered was developed based on a review of multi-unit PRAs. This list was supplemented with insights from operating experience, NRC and industry studies, and ongoing research on calculating source terms for Level 3 PRAs at multi-unit sites.

- External events were chosen deterministically based on single- and multi-unit studies, and based on the event at Fukushima, which included expanding the external events examined to include combined effects events.

- Combinations of all operating modes and sources of radioactive materials must be addressed once designs mature sufficiently.

This process shows that development of a complete and sufficient list of multi-unit IEs requires input from diverse sources. No single source adequately identifies potential interactions between units at multiunit sites. Numerous "types" of multi-unit IEs that are not currently addressed in single- or multi-unit PRAs were identified in this review, further showing that current studies are incomplete because they only address a subset of the problem. Prior to developing a multi-unit PRA, practitioners should read the events captured in the Appendices to this report understand and appreciate the subtle interactions and dependencies that exist at multi-unit sites. 



\section{INTRODUCTION}

To properly assess the risk and identify the risk drivers at multi-unit sites, the licensing basis must assess the risk from accidents that could affect multiple units. For example, the "dual-unit SBO [station blackout] accounts for 37 percent of the total CDF [core damage frequency] compared with only 2.3 percent from single-unit SBO.'[1] Thus, where SBO is a small part of the risk for a single unit, it is a significant contributor to the dual-unit or site risk. Regulations for licensing a nuclear power plant (NPP) recognize the potential for multi-unit accidents; however, the licensing basis for the current fleet of NPPs does not require a site-wide evaluation of risk because each NPP in the US has a separate license.

Licensees assess plant risk using probabilistic risk assessments (PRAs). With few exceptions, PRAs are performed on a per-unit basis. An initiating event (IE) is a failure event that, in the absence of adequate mitigating functions, may lead to the displacement of radioactive materials from their normal locations in plant systems and/or structures. IEs are used as starting points for identifying susceptibilities and for conducting PRAs. Normal locations of radioactive material include the reactor core and connected systems, processing and support systems, and storage systems. Selecting a complete and representative set of IEs is one of the most important tasks for determining risk.

This report identifies types of initiating events that should be reviewed for any of the advanced small modular reactor (AdvSMR) designs. The modular design of AdvSMRs increases the likelihood that a single reactor unit's IE can affect another reactor. The increased sharing of systems and structures and the close proximity of units results in an increased level of direct and indirect interactions among the reactor units. Therefore, the PRAs for modular reactor designs need to specifically address the increased interactions and dependencies. Current assessments will continue to underestimate site risk and improperly identify risk drivers until (1) multi-unit interactions are understood, (2) comprehensive lists of multi-unit IEs become available, and (3) guidance on modeling multi-unit accident scenarios become available.

\subsection{IMPORTANCE OF MULTI-UNIT PRAS}

PRAs are usually performed for a single unit, even for those units at a multi-unit plant site. Singleunit PRAs do not evaluate the integrated site risk and the selection of IEs is typically limited to the unit under review (i.e., no initiators from other units). In those instances where the single unit PRA recognizes a connection to another unit through a shared system, the single-unit PRA typically only credits the crossties between units. An example of the benefits of being able to crosstie systems is the ability to cross-connect mechanical systems and electrical power between units. Consider that Fukushima Dai-ichi units 5 and 6 and Fukushima Daiini avoided damaging the reactor cores following the tsunami by crosstying electrical power sources between units.

While single-unit PRAs give credit to the ability to crosstie systems, they do not address any failures or IEs that may result from the connection with any other units. For example, a normally isolated connection between units may fail because of an external hazard (e.g., a seismic event) that affects both units. Another limitation of a single-unit PRA is that when performed in isolation, it may erroneously credit coupled systems without considering the status of that system at the coupled unit. For example, credit was taken for the ability to crosstie the essential service water (ESW) system at Byron. Because the assessment did not consider the allowance to remove the entire system from service if a plant is shut down, the PRA failed to recognize that under these conditions, the ability to crosstie the ESW systems was nonexistent.

Large, "independent" plants typically share support systems such as electric power; control and service air; heating, ventilation, and air conditioning (HVAC); radwaste; service water; raw cooling water; fire protection; plant communication systems; etc. Single-unit PRAs have addressed direct

\footnotetext{
*The only IEs explicitly excluded from the scope of this review are accidents resulting from purposeful human-induced security threats (e.g., acts of sabotage and terrorism).
} 
couplings between units at a multi-unit site in a limited manner. For example, Westinghouse recognized the importance of support systems in determining the risk at a single plant by designating the loss of some support systems as special initiating events in the PRA for the AP600/AP1000. The support systems included the component cooling water system, the service water system, and the compressed air system. Losses of these support systems were labeled as "special initiating events" because they could result in a reactor trip and affect the performance of the front-line systems (e.g., normal residual heat removal, passive residual heat removal, core makeup tank, and main and start-up feedwater).

While the consideration of "special initiating events" may assess the risks associated with shared systems, it does not assess the risks of proximity IEs (e.g., loss of offsite power [LOOP], floods), common-cause failures, etc. A multi-unit or site-wide PRA would evaluate these risks. Consider that the explosion in Fukushima Unit 4 was likely caused by hydrogen leaking from Unit 3 to Unit 4 through a common venting system. [2] With a higher degree of coupling between units and modules, modular reactors would have more unlikely or unrecognized couplings that can increase risk. For example, PRISM shares 59 of its 74 systems, or $80 \%$ (Appendix A).

Highly interconnected plants such as PRISM highlight the need for multi-unit PRAs, and they also show the complexities of identifying IEs and performing a site-wide risk analysis. Unconventional and/or reconfigurable balance-of-plant arrangements may pose control challenges because of the effects of operating mode transitions or dynamic links among interconnected systems. In-service reconfiguration of equipment lineups and flow interconnections to support product stream transitions can lead to significant transients. Propagation effects from dynamic connections of different production systems (e.g., turbinegenerator for electricity, thermal systems for desalination or hydrogen production) can lead to adverse feedback of downstream upsets. A shared control room and staff response, especially when an initiating event at one reactor requires/initiates action at another reactor, presents the need for another set of interactions that are currently not measured or explored in single-plant PRAs. Thus, a PRA measuring the risks associated with a single reactor unit will fail to identify and measure the risk of interactions between and across units. To properly assess the risk at multi-unit plant sites, the first step is to identify potential multi-unit plant site EIs.

Most PRAs developed to date do not explicitly consider multi-unit accidents in which initiating events lead to reactor core damage in multiple units at the same site. Current PRA models therefore do not appropriately identify and address dependencies between systems at multi-unit sites, particularly those with highly complex support system dependencies involving systems and subsystems that are shared by multiple units. This review first looked at several PRAs that evaluated the risks associated with multiple units at a site. Because the design philosophy at modular plants is to maximize the sharing of services and facilities, this review also looked at the PRAs of modular plants to identify multi-unit IEs. The benefits of these reviews were minimal because, although they evaluated multi-unit risks, the list of IEs was incomplete.

The PRAs for modular reactors need to specifically address the increased interactions and dependencies between units. Current assessments will continue to underestimate site risk and improperly identify risk drivers until (1) multi-unit interactions are understood, (2) comprehensive lists of multi-unit IEs become available, and (3) guidance on modeling multi-unit accident scenarios become available. An example of the importance of understanding the risk at multiple sites can be seen in the analysis of the Tennessee Valley Authority (TVA) Browns Ferry Nuclear Plant. The multi-reactor plant PRA for this plant estimated a CDF four times greater than that for Unit 2 alone. [3] This illustrates how an incomplete set of IEs will result in an incorrect picture of site risk.

\subsection{OPERATING STATES}

Single-unit PRAs identify IEs for the different operating states including at-power, startup/low power, shutdown, and refueling. The PRA must also consider construction events affecting an operating plant. As shown by the ESW event described earlier, multi-unit PRAs must identify IEs for the combinations of different operating states for each unit, including construction. 
The conditional probability of a multiple core accident (CPMA) is not applicable to single-unit PRAs and is not considered in multi-unit PRAs given core damage on either unit. Fleming estimated the CPMA at Seabrook as equal to 0.14. [4]. Seabrook does not share many support systems and structures equal. The CPMA at Braidwood, where systems and structures are shared extensively, is equal to 0.67; thus most core damage events at these plants would be involve both units.

\subsection{POTENTIAL HAZARDS}

Combinations of events involving reactors, spent/used fuel pools, and/or dry storage casks should be addressed. As an example of why this is important, consider that there are four broad interplays that can be defined between the spent fuel pool (SFP) and the reactor: [5]

1. An IE can directly affect both the reactor and the SFP.

2. A reactor accident that prevents accessibility to the SFP for a prolonged period of time (e.g., because of high radiation fields) could lead to an SFP accident.

3. A reactor accident that includes ex-containment energetic events (e.g., a hydrogen combustion event) or other ex-containment interplays (e.g., steaming through the drywell head that affects refuel floor combustible gas mixtures) and creates a hazard to the SFP (e.g., by causing debris to fall in to the pool) or otherwise, changes the SFP event progression $\dagger$.

4. An SFP accident can prevent accessibility to key reactor systems and components for a prolonged period of time, or it can create a hazard for equipment used to cool the reactor (e.g., the flooding of low elevations of the reactor building due to a leak in the pool or excessive condensation from continuous boiling of SFP water). These conditions can lead to a reactor accident.

For each of these interplays, large seismic events and severe weather SBO events are logically the most relevant initiators, as they are the type of EIs most likely to initiate an accident at the reactor and SFP while simultaneously hampering further accessibility to key areas, key systems and components, and key resources. To the extent practicable, PRAs can qualitatively account for some of these effects. For example, when the reactor and SFP are hydraulically connected during refueling, the decay heat and water volumes from both sources can be considered.

\subsection{POTENTIAL HAZARDS}

For each distinct source and each operating state, the multi-unit PRA should identify mechanisms that could lead to the displacement (release) of radioactive material. The PRA should group the list of potential IEs by similarity of plant response (mitigating action) and/or bounding consequences into a single, bounding, higher-level event. As noted earlier, this approach is applied to combinations of sources and operating states.

\subsection{SYSTEMATIC REVIEW PROCESS TO IDENTIFY MULTI-UNIT INITIATING EVENTS}

The Nuclear Regulatory Commission (NRC) approach for evaluating accidents is based on the deterministic selection of IEs. [6, 7] However, because the risks and risk drivers vary significantly for multi-unit sites compared to single-unit sites, and the limited insights provided in the review of existing multi-unit PRAs, the types of documents reviewed for insights into possible multi-unit interactions were

\footnotetext{
$\dagger$ For instance, a hydrogen combustion event caused by a reactor accident that affects the refuel floor superstructure can lead to additional oxidation (for an otherwise oxygen-limited situation), which in turn may result in higher releases from the SFP. Note that this can also include positive effects, in the sense that steam leaking through the drywell head can serve to steam inert the refueling floor.
} 
expanded. That is, selecting potential multi-unit IEs the same as had been done previously would lead to an incomplete and misleading set of initiators.

The following approach was used to identify types of multi-unit IEs:

- A list of the types of multi-unit IEs to be considered was developed based on a review of multi-unit PRAs. This list was supplemented with insights from operating experience, NRC and industry studies, and ongoing research on calculating source terms for Level 3 PRAs at multi-unit sites.

- External events were chosen deterministically based on single- and multi-unit studies, and based on the event at Fukushima, which included expanding the external events examined to include combined effects events.

- Combinations of all operating modes and sources of radioactive materials must be addressed once designs mature sufficiently.

This process shows that development of a complete and sufficient list of multi-unit IEs requires input from diverse sources. No single source adequately identifies potential interactions between units at multiunit sites. In addition, an understanding and appreciation of how units can interact is necessary for assessing risk at multi-unit sites.

A probabilistic or risk-informed approach for identifying events to be considered in an applicant's design bases can be applied at a later date, provided that plant and fuel performance are sufficiently understood and deterministic engineering judgment is used to bound uncertainties. [8] 


\section{REGULATIONS/GUIDANCE}

Many NPPs are colocated at a single site. Specifically, there are 32 sites with two operating reactors and three sites with three operating reactors in the US $\ddagger$ In addition, some sites are physically near to each other such that they are essentially challenged by the same external hazards. (Hope Creek is near Salem Units $1 \& 2$, and FitzPatrick is near Nine Mile Point Units $1 \& 2$ ). Although $\sim 75 \%$ of operating reactors are at multi-unit sites, minimal regulations and guidance exists related to multi-unit sites.

The regulations, guidance, and historical perspective of multi-unit sites are provided below.

\subsection{REGULATIONS}

Although each NPP in the US has a separate license, the licensing basis under 10 Code of Federal Regulations (CFR) 50 and 52 recognize the potential for multi-unit accidents.

10 CFR Part 50, Appendix A, "General Design Criterion" (GDC) 5 is intended to address features of a multi-unit site that could allow problems to propagate from one unit to another. The criterion states:

Structures, systems, and components important to safety shall not be shared among nuclear power units unless it can be shown that such sharing will not significantly impact their ability to perform their safety functions, including, in the event of an accident in one unit, an orderly shutdown and cooldown of the remaining units.

Prior to the development of GDC 5, multi-unit sites frequently made use of shared systems and structures. Service water systems, control rooms, and other features were often shared. While each unit included enough redundancy to respond to an accident without consideration of the other units, it was possible for an event at one location to affect multiple units at the same time. After the 1975 Browns Ferry fire damaged safety systems at two units, new multi-unit sites were designed with complete separation, providing separate components and structures for all important systems. [9]

10 CFR 50.55a(h) requires compliance with the Institute of Electrical and Electronics Engineers (IEEE) Std. 603-1991, including the correction sheet dated January 30, 1995. This standard includes Section 5.13, "Multi-unit Stations," which states the following:

The sharing of structures, systems, and components between units at multi-unit generating stations is permissible provided that the ability to simultaneously perform required safety functions in all units is not impaired.

10 CFR 100.11(b), which provides requirements for determining the exclusion area, the low population zone, and the population center distance for multi-unit sites, states the following:

Subsection (b)(1): If the reactors are independent to the extent that an accident in one reactor would not initiate an accident in another, the size of the exclusion area, low population zone and population center distance shall be fulfilled with respect to each reactor individually.

Subsection (b)(2): If the reactors are interconnected to the extent that an accident in one reactor could affect the safety of operation of any other, the size of the exclusion area, low population zone and population center distance shall be based on the assumption that all interconnected reactors emit their postulated fission product releases simultaneously.

\footnotetext{
\$ These counts exclude the two-unit San Onofre site where both units are being permanently shut down, the two additional units under construction at the Summer site, and the two additional units under construction at the Vogtle site.
} 
10CFR52.47(c)(3) requires that the potential impact of an accident in one unit affecting the safe shutdown of other units must be explicitly addressed in the scope of the design criterion, and it requires an analysis of "the possible operating configurations of the reactor modules with common systems, interface requirements, and system interactions."

10CFR52.79(a)(31) addresses the review of an evaluation of potential hazards to the structures, systems, and components (SSCs) important to safety of the operating units resulting from construction activities, as well as a description of the managerial and administrative controls to be used to provide assurance that the limiting conditions for operation are not exceeded as a result of construction activities at multi-unit sites. The requirements of 10 CFR 52.79(a)(31) are intended to apply both to construction activities and subsequent operation of the new unit(s) analogous to the provisions of 10 CFR 50.34(a)(11) and 10 CFR 50.34(b)(6)(vii) for units licensed under the Part 50 regime. The requirement in 10 CFR 52.79(a)(31) can be viewed as having two subparts: [10]

1. The combined operating license (COL) applicant must evaluate the potential hazards from constructing new plants on SSCs important to safety for existing operating plants that are located at the site.

2. The COL applicant must evaluate the potential hazards from constructing new plants on SSCs important to safety for newly constructed plants that begin operation at the site.

The regulations specify that the licensing bases (1) allow the sharing of systems between units, (2) require an assessment of multi-unit site risks, and (3) require the evaluation of construction risks.

\subsection{GUIDANCE}

Guidance for meeting requirements is provided in regulatory guides and industry standards that are endorsed by regulatory guides. Guidance for multi-unit sites is limited in that it is recommended that multi-unit initiators be identified and evaluated. Examples from relevant standards are provided below.

ASME [American Society of Mechanical Engineers]/ANS [American Nuclear Society] RA-Sa-2009 [11] (endorsed by RG 1.200, with exceptions), establishes requirements for a Level 1 PRA of internal and external hazards for all plant operating modes. With respect to multi-unit IEs, this standard states the following:

IE A10: For multi-unit sites with shared systems, INCLUDE multi-unit site initiators (e.g., multiunit LOOP events or total loss of service water) that may impact the model.

IE B5: For multi-unit sites with shared systems, DO NOT SUBSUME multi-unit initiating events if they impact mitigation capability.

The standard requires that multi-unit initiators, events, and sequences be included in the PRA, but as expected, it does not provide prescriptive requirements or examples of how to implement the requirements.

The International Atomic Energy Agency (IAEA) has addressed the sharing of structures, systems and components between reactors $[12,13]$ as follows:

Structures, systems and components important to safety shall generally not be shared between two or more reactors in nuclear power plants. If in exceptional cases such structures, systems and components important to safety are shared between two or more reactors, it shall be demonstrated that all safety requirements are met for all reactors under all operational states (including maintenance) and in design basis accidents. In the event of a severe accident involving one of the reactors, an orderly shutdown, cooling down and removal of residual heat shall be achievable for the other reactor(s). 
NEI [Nuclear Energy Institute] 00-02, IE-6, (endorsed by RG 1.200, with exceptions), states that "For multi-unit sites with shared systems, the impact of initiators requiring simultaneous response (e.g., LOOP, loss of cooling source due to ice, loss of an ac [alternating current] or dc [direct current] bus, etc.) are included."

The regulatory guidance, as expected, provides more insight into how the design can meet GDC 5, although the statements are still general and focus attention on shared systems.

\subsection{IMPLEMENTATION AND HISTORICAL PERSPECTIVE}

Most PRAs developed to date do not explicitly consider multi-unit accidents where IEs lead to reactor core damage in multiple units at the same site. Current PRA models therefore do not generally identify and address dependencies between systems at multi-unit sites, including those with highly interdependent support systems involving systems and subsystems shared by multiple units. To understand how these multi-unit effects contribute to the risk associated with an NPP, PRA models must be enhanced to include both IEs that might simultaneously impact multiple units and equipment and human action dependencies in responding to multi-unit accidents. [14]

The licensing bases for the Next Generation Nuclear Plant (NGNP) and the Pebble Bed Modular Reactor (PBMR) did commit to enhancing PRA models to evaluate the integrated site risk. More specifically, the NGNP stated licensing basis stated the following:

The PRA ... will include the integrated risk of the multi-module station including sequences with releases from one or more reactor modules. [15]

The PBMR stated

Each licensing basis event (LBE) includes an appropriate definition "to support the integrated risk from a multi-module plant. [16]]

In 1996, an Idaho National Laboratory (INL) study considered a dual-unit plant and included the following multi-unit IEs:

- loss of SFP cooling

- LOOP

- loss of SFP water inventory (did not include heavy load drops)

- loss of primary (reactor) coolant

- seismic events

Interestingly, the INL study showed that, depending on the design characteristics of a given plant, the likelihood of either (1) core damage from SFP-associated flooding or (2) spent fuel damage from pool dry out may not be negligible. The INL study also noted that, along with the possibility of a concurrent SFP and reactor accident, there is the possibility for a concurrent accident at the SFP of one unit with an accident at the SFP or reactor of the other unit. Again, a large seismic event or a severe weather SBO are the events that are most likely to lead to a multi-unit event. [17]

From an historical perspective, any new plant will be required to probabilistically evaluate the risks posed by multi-units at a site simultaneously and will need to consider other radiological risks in addition to reactor core upsets. This historical perspective also highlights the fact that other sources of radiological material (e.g., in the SFP) must be included in the list of potential multi-unit IEs. 


\subsection{POST FUKUSHIMA-RELATED GUIDANCE}

Even after the Fukushima Dai-ichi accident, NRC staff members concluded in the NRC's Near Term Task Force Report that "a sequence of events like those occurring in the Fukushima accident is unlikely to occur in the United States and could be mitigated, reducing the likelihood of core damage and radiological releases." [18] However, this unlikeliness is probably a function of the tsunami.

The explosion at Fukushima Unit 4 did show that vulnerabilities from crossties and common venting systems can increase the risk to unaffected units. [19] Thus, NRC is assessing the benefits of developing an all-modes, all-hazards, multi-unit model to better understand the different hazards. NRC is also updating their historical study. NRC views this event as significant on a PRA historical time line that would take PRA to the next level. [20]

Dependencies between multiple units on a site — internal, external, and operational — and their effects on overall site risk can only be understood by modeling these dependencies in a comprehensive and integrated site-specific PRA model. 


\section{TYPES OF INTERACTIONS, COUPLING ISSUES}

\subsection{TYPES OF INTERACTIONS}

To develop an initial set of multi-unit IEs, it is important to understand the types of interactions that can occur and to recognize that these interactions can be direct or indirect. Examples of these types of interactions are provided in Table 1.

Table 1. Types of interactions between units at a multi-unit site

\begin{tabular}{|c|c|c|}
\hline $\begin{array}{c}\text { Type of } \\
\text { interaction }\end{array}$ & Subset of interaction & Example of interaction \\
\hline \multirow[t]{4}{*}{ Direct } & Shared systems & $\begin{array}{l}\text { - Physical interconnections-fluid systems, electric } \\
\text { systems }\end{array}$ \\
\hline & Cross connects between units & $\begin{array}{l}\text { - Cable trenches, ventilation ducts, underground piping, } \\
\text { building connections }\end{array}$ \\
\hline & & - Non-envisaged [unforeseen] connections \\
\hline & Common-cause failures (CCFs) & - External events \\
\hline \multirow[t]{5}{*}{ Indirect } & Common locations & - Site, environment, building \\
\hline & Procedures & $\begin{array}{l}\text { - Recovery actions depend on actions at other unit; } \\
\text { staffing/resource allocation }\end{array}$ \\
\hline & & $\begin{array}{l}\text { - Security systems affecting site or local access (affects } \\
\text { recovery) }\end{array}$ \\
\hline & CCFs & $\begin{array}{l}\text { Containers with flammable or explosive substances, } \\
\text { nearby facilities, pipelines }\end{array}$ \\
\hline & & - Installation of portable equipment \\
\hline
\end{tabular}

The most commonly studied (and cited) interaction between units is that caused by the sharing of systems. Shared systems have the potential to:

- impact the success criteria for an individual system or group of systems,

- change the frequencies of IEs previously considered (i.e., the frequency of occurrence is affected by multi-reactor plant operation),

- introduce IEs not previously considered (i.e., new initiator categories associated with multi-reactor plant operation), or

- alter dependencies or introduce new dependencies among systems, or otherwise affect the response of the plant to initiating events (i.e., the response differs for single- and multi-reactor plant plants).

The indirect interactions between units at multi-unit sites were explored further. Based on the current review, the potential list of multi-unit IEs should include the correlations provided in Table 2 to account for the combination of external events: 
Table 2. Correlated multi-unit IEs

\begin{tabular}{ll}
\hline \multicolumn{1}{c}{ Correlated hazard } & \multicolumn{1}{c}{ Example } \\
\hline Source (i.e., same source of origin) & seismic hazard and tsunami \\
Phenomenological & strong winds and heavy rain \\
Duration correlated hazards & any external hazards occurring during a prolonged hot summer \\
& temperature period \\
Induction mechanism & seismic hazards and seismically induced fire, etc. \\
\hline
\end{tabular}

Because PRAs address external events singularly (i.e., the IEs are not correlated), the indirect interactions between units at multi-unit sites were explored further. A structured process is required to ensure completeness in identifying correlated hazards. This agrees with and expands on the NRC's conclusion regarding its Individual Plant Examination External Events (IPEEE) Program, which concluded that IPEEEs should adequately address seismically induced events such as seismically induced fires, floods, and/or spatial and functional interactions. [21]

If the external event is sufficiently large to require that it be listed as an IE, typically correlated IEs should also be included. Thus, the current review identified the following correlated hazards:

- Seismically induced LOOP

- High winds induced LOOP

- $\quad$ Tornado induced LOOP

Based on the current review, the potential list of multi-unit IEs should include the correlations discussed below to account for the coupling of external events such as those listed above.

\subsection{HOW IES INTERACT}

The current understanding is that multi-unit PRAs are mostly driven by external events that could affect both units. The NRC has discussed this with the Advisory Committee on Reactor Safeguards (ACRS) and recognizes that the dependencies between multiple units on a site and their effect on overall site risk can only be understood by modeling the dependencies in a comprehensive and integrated sitespecific PRA model. This requires understanding cascading and propagating event sequences. Related excerpts from the Reliability and PRA Subcommittee meeting of March 5, 2014 are provided below: [22]

The typical PRA looks at one radiological source. . . And so we fixate on one source. The issue here is, we could have multiple combinations of radiological sources being impacted, as happened at Fukushima. So looking at the types of radiological hazards on the site, we have the fuel inside the reactor, spent fuel that's stored in the pools, or dry cask.

And it is not just considering when the reactor is operating, but during various shutdown and low power states of operation. So Unit 1 could be operating, Unit 2 could be in refueling, and some sort of accident occur....

Thinking about it [risk] in a multi-unit environment, we have to realize that any sequence may cause an initiating event in the other units at the site. For example, one could imagine an initiating event that occurs, say at Unit 1, say a [loss of coolant accident] LOCA. And Unit 1 behaves as expected. And the effects of that LOCA are mitigated, and there's no core damage.

At the same time the other units will see perhaps a consequential loss of offsite power, due to the drop of load when Unit 1 went down. Now they're the ones being challenged. So it's inappropriate simply to focus on extending the core damage sequences for one unit into the other units. 
You have to worry about these success paths of the event tree, that could also serve as initiating events for the other units, like this. And of course, floating around here is the need to consider the dependency among all the units, the shared systems. Those are the most obvious ones.

... one thing that stands out is there are different types of initiating events with respect to multiunit risk.

So I've labeled them Common Cause Initiators (CCIs). Something that challenges or trips all of the units at the site, basically at the same time, like a big earthquake. It could be a flood.

Generally, some sort of external event. Perhaps a loss of grid transient, something like that.

And that's in contrast to what I will call Single Unit Initiators, or SUIs, that says one unit gets challenged. But it propagates over to the other units because of the shared systems, or some sort of spatial interactions, you know, a fire could propagate over, some sorts of common cause failures across the units, and operator actions.

An example of a spatial interaction is actually what happened at Chernobyl. When Unit 4 happened, the graphite moderator was ejected, and it landed on the roof of Unit 3, and actually set it on fire. Now, it didn't burn through, but it's an example of a sort of phenomenon that I'm looking for.

The excerpts above refer to CCIs, cascading sequences and SUIs, or propagating sequences (Fig. 1). Examples of these types events are provided in Table 3, along with proximity events and external events.

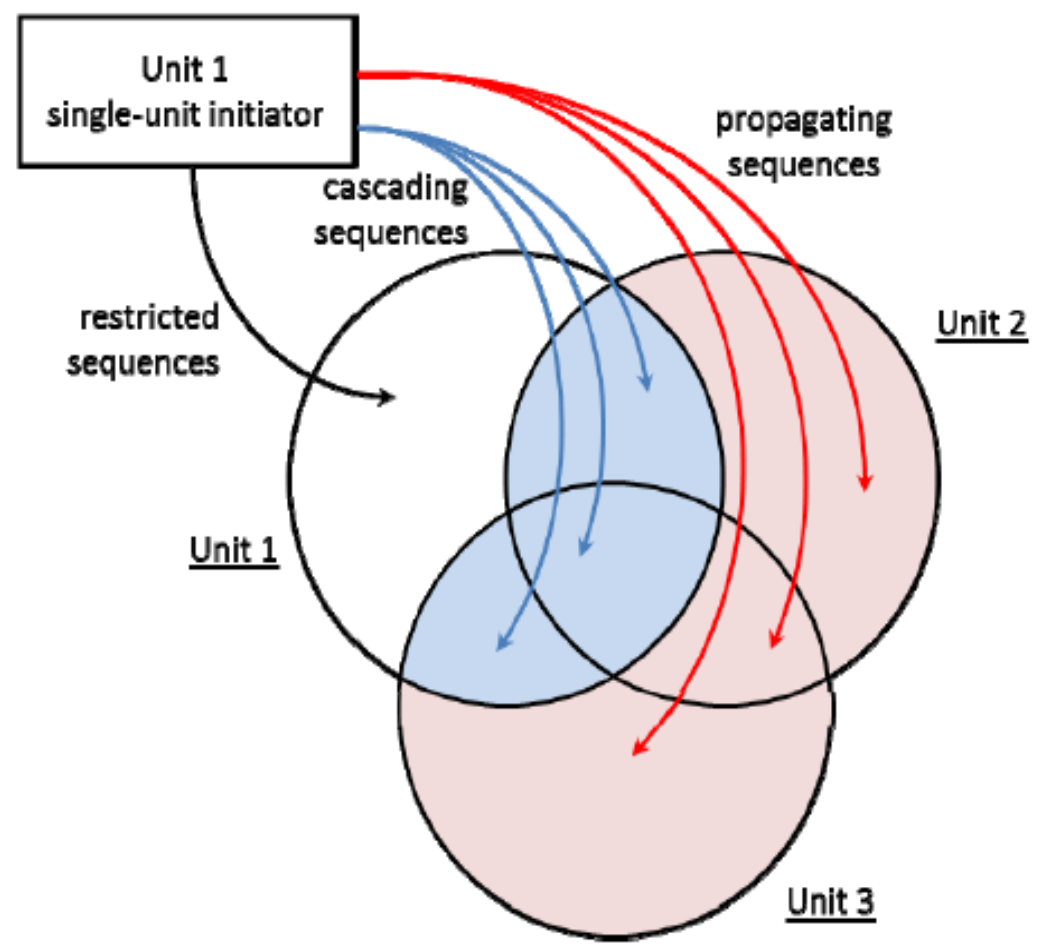

Fig. 1. Types of multi-unit IEs. [23] 
Table 3. Types of multi-unit IEs

\begin{tabular}{|c|c|}
\hline Multi-unit IE type & Example \\
\hline $\begin{array}{l}\text { Proximity event } \\
\text { sequence }\end{array}$ & - $\quad$ Drop of 529 ton stator onto turbine deck floor caused LOOP at Unit 1, transient at Unit 2 \\
\hline $\begin{array}{l}\text { Cascading event } \\
\text { sequence }\end{array}$ & $\begin{array}{l}\text { - Loss of unit auxiliary transformer (UAT) at Unit } 1 \text { results in loss of component cooling } \\
\text { water }(\mathrm{CCW}) \text {, which was crosstied to Unit 2; caused transients at both units } \\
\text { - Incorrect operator response (manual scram) based on transient at the other unit and what } \\
\text { the operator heard }\end{array}$ \\
\hline $\begin{array}{l}\text { Propagating event } \\
\text { sequence }\end{array}$ & $\begin{array}{l}\text { - Electrical fault at Unit } 1 \text { caused a grid disturbance, which in-turn caused a trip of Unit } 2 \\
\text { - } \quad \text { Generator trip at Unit } 2 \text { caused voltage transients on emergency buses at Unit } 1\end{array}$ \\
\hline $\begin{array}{l}\text { External event } \\
\text { sequence }\end{array}$ & $\begin{array}{l}\text { - Grid disturbances (e.g., voltage, current) where offsite power remained available and } \\
\text { caused transients at both units } \\
\text { - Undervoltage generated in switchyard, not offsite transmission system, caused transients } \\
\text { at both units. }\end{array}$ \\
\hline $\begin{array}{l}\text { Restricted event } \\
\text { sequence }\end{array}$ & - IE does not propagate or cascade to the other unit \\
\hline
\end{tabular}

\subsection{NUMBER OF COMBINATIONS}

Multi-unit initiators are IEs that occur at one or more units and ultimately affect one or more units. For simplicity, examples in the literature focus on two-unit sites. This is because a dual-unit site has three possible outcomes (two single-unit, one dual-unit) while a three-unit site has seven possible outcomes (three single-unit, three dual-unit, and one triple-unit). In addition, it would appear that the qualitative argument that a single IE affecting three units simultaneously would be very unlikely and need not be considered further. However, operating experience shows that this is indeed a reality. As detailed in Appendix C, of the 39 operating events that impacted more than one unit at a site between 1988-2014,

- 34 IEs affected both units at a dual-unit site,

- 3 IEs affected 2 of 3 units at a 3-unit site [24, 25, 26], and

- 2 IEs affected all 3 units at a 3-unit site [27, 28].

In summary, the identification of IEs and subsequent analyses must include all possible combinations of units. Increasing the complexity of the problem also accounts for all sources of potential hazards (e.g., the Standard Review Plan [SRP]). 


\section{PROBABILISTIC RISK ASSESSMENTS AND INDIVIDUAL PLANT EXAMINATIONS}

PRAs are used to estimate risk by identifying what can go wrong, how likely it is that something can go wrong, and determining the consequences. Thus, PRAs provide insights into the strengths and weaknesses of the design and operation of an NPP. To understand the contribution of multi-unit effects to the risk associated with an NPP, PRA models must be enhanced to include (1) IEs that might simultaneously impact multiple units and equipment and (2) human action dependencies in responding to multi-unit accidents. As with single-unit PRAs, selection of IEs for the multi-unit PRA is one of the most important tasks for determining risk. A list of IEs that neglects important initiators results in an erroneous assessment of plant risk and incorrectly identifies the contributors to plant and unit risk.

Single-unit PRAs do not evaluate integrated site risk. That is, IEs are limited to the unit under review (i.e., no initiators from other units). This is common practice. Even the PRISM PRA, which has three reactors in a single module, only evaluated the risks from each single reactor. However, multi-unit PRAs and operating experience show that even independent units are coupled. That is, physically coupled IEs and proximity IEs are likely to impact multiple units (e.g., LOOPs, support system failures, and floods).

\subsection{PROBABILISTIC RISK ASSESSMENTS AND INDIVIDUAL PLANT EXAMINATIONS}

Although many NPPs are colocated at a single site, with few exceptions, PRAs of NPPs have focused on estimating the risk of a single NPP that may or may not be colocated with other NPPs. [29]

Only a few integrated site risk assessments were found to be available for review:

- Browns Ferry multi-unit PRA [3]

- Seabrook probabilistic safety assessment (PSA) [30]

- Byron/Braidwood individual plant examination (IPE) [31]

- Modular High-Temperature Gas-Cooled Reactor (MHTGR) PRA [32]

Single-unit PRAs credit crossties between units; crossties typically involve systems such as electric power, auxiliary feedwater, service water, and various water storage tanks. For example, the ability to cross-connect mechanical systems and electrical power between units at Fukushima Dai-ichi units 5 and 6 and similarly at Fukushima Daiini greatly improved the operator's response following the tsunami.

The multi-unit PRAs reviewed evaluated the added risk of crossties and shared systems between units. However, the PRAs reviewed take credit for crossties, but they do not include undue problems in the models. For example, the use of crossties may leave the potential for some additional shared systems to have an inadequate number of available components or inadequate flow rates when one unit is shut down and the other unit is operating (e.g., Byron ESW analysis). In another example, a normally isolated connection between units may fail because of an external hazard (e.g., seismic event). Similarly, a likely cause of the explosion in Fukushima Unit 4 is that hydrogen leaked from Unit 3 to Unit 4 through a common venting system.

The multi-unit PRAs reviewed did not evaluate the following issues:

- Radiological consequences from a damaged unit or waste storage vessels/structures that may affect the safety (and recovery actions) of other units.

- Accident response resource limitations and errors that can hinder recovery at one unit, which may initiate IEs at colocated units (e.g., movement of flammable or explosive substances from a damaged unit, competing resource demands between the reactor and the SFP, etc.).

- An unforeseen or unplanned connection between plant compartments or buildings that may exist or may be caused by an external hazard.

Multi-unit IEs also must consider and identify IEs for shutdown units, even if they are prematurely shutdown. Systems not normally analyzed (e.g., security systems affecting site or local access); offsite organizations (directly affecting operations through suggestions such as delaying saltwater injection, or 
indirectly through requests for information); and post-accident risk associated with a stabilized but severely damaged site should all be included when considering multi-unit IEs and in planning recovery actions.

Another potential multi-unit IE not addressed in current assessments is low-trajectory missiles from a turbine at one unit that affect safety-related systems and components at the other unit. In their review of the AP1000, NRC requested Westinghouse to provide a bounding turbine missile analysis for lowtrajectory missiles or provide an action item requiring COL applicants to provide a turbine missile analysis for low-trajectory missiles at dual-unit sites. [30]

Multi-unit PRAs have focused on events that lead to core damage. Neglected items included IEs associated with the SFP, dry cask storage, or any other potential release of radiological material. To understand the contribution of multi-unit and nonreactor effects to the overall site risk, PRA models must be enhanced to address, among other items, the following:

- IEs common to multiple reactors and/or SFPs and dry casks (i.e., all sources of radiological material, not just the reactors themselves)

- Common or dependent equipment and operator actions between multiple reactors and/or spent fuel pools and dry casks

The simplest and most likely method of estimating the likelihood of a multi-unit event is to simply multiply by the number of units. For example, DOE-HTGR-86-011/Rev. 3 states that

... in a multiple reactor plant such as the MHTGR, multiple reactors could be impacted at one time if support systems are shared or if an external event threatens all units. In such cases, the consequences of the event sequence could be increased in proportion to the number of units affected.

That is, the MHTGR PRA assumes that

$$
\mathrm{CDF}_{\mathrm{n} \text { units }}=\mathrm{n} \text { units } * \mathrm{CDF}_{\text {single unit }}
$$

However, the Browns Ferry PRA estimated that the CDF increased by a factor of 4 for 3 units, while the Seabrook PSA shows a multiplier of 1.87 for the CDF for 2 units.

Selection of IEs is one of the most important tasks for determining risk. A list of IEs that neglects important initiators will result in an erroneous assessment of plant risk.

Current multi-unit PRAs use an incomplete list of multi-unit IEs. The multi-unit PRAs reviewed only include the typical IEs (Appendix C):

- LOOPs caused by equipment, personnel, weather, and seismic conditions, and

- failure of shared systems.

Operating experience shows unexpected and/or unanticipated couplings between units because of

- cascading or propagating events (e.g., through shared systems) or site-wide events (e.g., seismic, flood)

- Combined effects (e.g., seismically induced flood)

Thus, the multi-unit PRAs have an inadequate treatment of multi-unit dependencies, and they also have a tendency to take too much credit for the extra hardware while giving too little attention to unfavorable interactions.

An improper or inadequate model may be worse than no model. Most core damage events would be multi-unit events, even for those units that have minimal sharing. The risk of multi-unit events increases significantly regardless of the degree of shared support systems, structures, and proximity. With a 
complete list of multi-unit IEs and a more complete understanding of recovery actions, modeling techniques and options can be explored.

A thorough list of multi-unit IEs is necessary to overcome the deficiencies in current risk assessments. For example, the typical list of single-unit IEs ${ }^{\S}$ will underestimate plant and site risk. Furthermore, a list of multi-unit IEs that excludes other sources of radiological hazards will underestimate site risk. ${ }^{* *}$ Finally, a list of multi-unit IEs that neglects operating states other than full power ${ }^{\dagger \dagger}$ will underestimate plant and site risk.

\subsection{IAEA}

The number of sites housing multi-unit NPPs and other colocated nuclear installations is increasing. An external event may generate one or more correlated hazards or it may result in a combination of unrelated hazards arising from different originating events. All of these events can threaten the safety of NPPs and other nuclear installations. While the safety assessment of a site with a single-unit NPP for external hazards is challenging, the task becomes even more complex when the safety evaluation of a multi-unit site is to be carried out with respect to multiple hazards.

The impact of the Niigataken Chuetsu-oki (NCO) earthquake in July 2007 on the KashiwazakiKariwa NPP highlighted the need to develop a methodology and detailed guidelines for the safety assessment of sites, especially those housing multi-unit NPPs and other nuclear installations, with regard to multiple correlated hazards generated by an external event (e.g., earthquake induced ground motion and fire). The Fukushima Dai-ichi nuclear accident caused by the Great East Japan earthquake and tsunami on 11 March 2011 underlined the importance of initiating a comprehensive range of activities related to the safety assessment of multi-unit sites for multiple hazards. The lessons learned from these accidents suggest that safety assessments should consider multiple hazards and their potential effects on multiple units on a site, as the case may be.

Currently available guidance for the safety assessment of NPP sites in relation to external events is not comprehensive, although there are well established methodologies for the evaluation of risk or safety margins against seismic ground motion hazards based on both deterministic (seismic margin assessment [SMA]) and probabilistic (seismic probabilistic safety assessment [SPSA]) approaches. There is no wellestablished methodology for other external events such those caused by flooding (inundation, hydrodynamic forces, and clogging). This is also the case for the combined effects of main shock, aftershocks, and associated events following the main shocks of an earthquake. Guidance is also lacking for site safety evaluations that combine the risks for multiple units and consider common cause failure under multiple hazards.

Based on the discussions above, activities aimed at developing detailed guidelines on site evaluation and safety assessment with respect to external events, with an emphasis on multi-unit sites, have been taken up in Work Area 8 (WA8) of the International Seismic Safety Centre's Extra Budgetary Programme

\footnotetext{
$\S$ Typical IEs in PRAs include:

- Loss of grid

- Consequential LOOP

- Internal hazards (fires, floods)

- External hazards (seismic, floods, high winds)

** Sources of radioactive material excluded in older PRAs include:

- Reactors

- $\quad$ Spent fuel pool

- Dry cask storage

$\dagger \dagger$ Operating states that should be in PRAs include:

- Full power

- Low power/shutdown

- $\quad$ Refueling

- Construction

- Damaged state
} 
(ISSC-EBP). The information shared during the workshop will be used in the work being carried out under WA8.

The safety assessment of a multi-unit NPP site with regard to multiple external hazards is a complex task. In order to develop detailed guidelines and a methodology in this area, it is necessary to share the experience and ideas of the international nuclear community. The proposed International Workshop on the Safety of Multi-Unit Nuclear Power Plant Sites against External Natural Hazards will provide an appropriate platform to share such information.

The main objective of the workshop is to share information within the international nuclear community on the scientific and technical issues related to the safety of multi-unit NPP sites against external natural hazards that need to be addressed following the Fukushima Daiichi nuclear accident.[31]

The workshop will also highlight the activities undertaken by the IAEA and its Member States to meet the challenge of ensuring the safety of multi-unit sites against multiple external hazards.

The workshop will cover the following main topics: lessons learned from past earthquakes affecting NPPs, assessment of external natural hazards at a site housing multi-unit NPP(s) and other nuclear installations, external event probabilistic safety analysis (EE-PSA), risk integration, and external event site safety assessment. 


\section{OPERATING EXPERIENCE}

\subsection{OPERATING EXPERIENCE REVIEW}

A review of the operating experience from 1980 to the present was performed to identify IEs that affected more than one unit at multi-unit plant sites (Appendix B). The review recognizes that the units may be in different operating conditions. For example, (1) some systems may not be available because technical specifications allow more equipment to be inoperable during low power and shutdown (LPSD) conditions than at power, (2) LPSD IEs (by definition) impact the operable train of decay heat removal systems, and (3) human errors are more likely because of the increase in activity during shutdown. Unusual equipment line-ups also make mistakes more likely. In addition, the proximity of construction and construction-related accidents would increase the likelihood of construction-induced IEs at the other unit, which may be at-power operations or shutdown.

The review identified the following multi-unit IEs with the potential to affect multiple units simultaneously:

- LOOPs caused by equipment, personnel, weather, and seismic conditions

- Shared systems (service water, ESW, intake bay, nonvital ac power, instrument air)

- Internal hazards (fires, floods)

- External hazards (seismic, floods, high winds)

More importantly, the review identified the following unexpected relationships between units:

- Grid disturbances (e.g., voltage, current) where offsite power remained available caused transients at both units.

- Undervoltage generated in a switchyard, not from an offsite transmission system, caused transients at both units.

- A man-made event (drop of a 529 ton stator onto a turbine deck floor) caused LOOP at Unit 1 and transient at Unit 2.

- A cascade event (loss of UAT at Unit 1 resulted in loss of CCW, which was crosstied to Unit 2) caused transients at both units.

- Lightning-induced voltage transients occurred at both units.

- An electrical fault at Unit 1 caused a grid disturbance, which in turn caused a trip of Unit 2.

- An incorrect operator response (manual scram) based on a transient at the other unit caused a transient at the unaffected unit.

- A transient at Unit 2 was caused by a transient at Unit 1 (generator trip caused voltage transients on emergency buses).

Multi-unit EIs are not limited to generating a trip signal at both units. That is, the EIs must consider the operational state of each unit, similar to shutdown PRAs in which EIs damage the reactor core without generating a trip signal.

Single-unit and multi-unit PRAs include LOOP events as IEs, but they do not include grid disturbances that may cause the plant to isolate from the grid or may cause a plant transient. In fact, an NRC review of the operating experience of NPPs [32] indicated that transmission system faults may involve multiple reactor trips but do not necessarily cause a LOOP event (Table 4). PRAs typically include LOOPs as IEs; this approach excludes grid disturbances in which the grid remains powered and the unit(s) may isolate from the grid. The importance of including a grid disturbance in the types of IEs to be considered is that the disturbance may cause a transient or a LOOP, and the response from each unit may be different. That is, one unit may experience a transient while the other unit experiences a LOOP. In 
addition, at this stage of a design, it is unknown whether the response to a grid disturbance will behave similarly to a generic transient or LOOP response.

Because the review was of licensed operating NPPs, no construction-related multi-unit IEs were identified. However, the proximity of construction and construction-related accidents to an operating unit will increase the likelihood of construction-induced IEs at another nearby unit, which may be at-power operations or shutdown.

In summary, not only LOOPs, but also electrical disturbances must be included in the list of multiunit IEs to be considered. These disturbances may initiate on the grid, in the switchyard, or from another unit on the site. Man-made IEs and proximity event sequences must also be included.

\subsection{FUKUSHIMA EVENT}

Multi-unit IEs can occur from sharing of equipment, proximity of plants and equipment, or external hazards. Because of the large contribution of external hazards such as seismic and flooding to plant risk, the March 11, 2011 earthquake and tsunami off the Fukushima coast was reviewed.

The accident at the Fukushima Dai-ichi NPP demonstrates the importance of properly identifying and understanding (1) the susceptibility of vulnerabilities to CCFs that can arise from natural phenomena events, (2) the measures available to mitigate the consequences of such accidents, and (3) possible limitations on the ability to execute emergency preparedness plans. The combined effects of the earthquake and the ensuing tsunamis also highlighted the need to evaluate concurrent related events, such as seismically induced fires and floods, not only at a single unit, but also at multiple units at a plant site.

Because of the proximity of units and the sharing of systems, the earthquake and tsunamis affected all six units at Fukushima Dai-ichi and all four units at Fukushima Daiini. These natural phenomena events resulted in the CCF of ac power, dc power, fire protection, the ultimate heat sink, and plant communications at the Dai-ichi units. Explosions damaged much of the equipment staged to vent the suppression chamber and the fire engines and hoses used to inject water into the reactor core. These natural phenomena events at Fukushima also show that vulnerabilities to CCFs extend to not only multiple equipment items, but also to different types of equipment items. Although staffing, procedures, training, supply lines, systems not associated with the removal of decay heat, etc., are not normally associated with CCFs, deficiencies in these areas should be considered as CCFs that hindered the ability to recover after the accident. 
Table 4. Transmission system faults that involved multiple reactor trips

\begin{tabular}{|c|c|c|}
\hline Plants & LER No. & Event \\
\hline $\begin{array}{l}\text { Diablo Canyon } 1,2 \\
\text { Palo Verde } 1,2 \\
\text { WNP } 2 \\
\text { San Onofre } 2\end{array}$ & $\begin{array}{l}275 / 94-020 \\
\text { PNO-IV-94062 }\end{array}$ & $\begin{array}{l}\text { On December 14, 1994, a transmission line fault in Idaho affected six } \\
\text { nuclear units in California and Arizona. The transmission system } \\
\text { experienced underfrequency, overfrequency, and low voltage, and the } \\
\text { grid separated into four islands. }\end{array}$ \\
\hline & & $\begin{array}{l}\text { Diablo Canyon Units } 1 \text { and } 2 \text { were at } 100 \text { percent power when the } \\
\text { transmission line fault resulted in Units } 1 \text { and } 2 \text { reactor trips due to } \\
\text { undervoltage to the reactor coolant pump motors. }\end{array}$ \\
\hline
\end{tabular}

The other four units affected did not trip. While at 100 percent power, several WNP-2 uninterruptable power supplies (UPSs) tripped off line and realigned to their alternate power source. Palo Verde Units 1 and 2 were operating at 98 and 100 percent power, received several UPS alarms, and reduced power 1 percent. San Onofre Unit 2 was at 98 percent power and lost $40 \mathrm{MWe}$ as a result of one of four turbine governor valves closing.

Diablo Canyon 1, 2 275/96-012

Palo Verde 1, 3 528/96-004

WNP 2

San Onofre 1, 2

Beaver Valley 1 \& 2 LER 334/97-005

Limerick $1 \& 2$
On August 10, 1996, a major electrical disturbance resulted from a fault on a $500 \mathrm{kV}$ transmission line that sagged into a tree in Oregon. The transmission system experienced underfrequency, overfrequency, and low voltage, and the grid separated into four islands.

Diablo Canyon Units $1 \& 2$ are in the northern island where the frequency dropped to $58.54 \mathrm{~Hz}$, spiked to $60.7 \mathrm{~Hz}$, dropped to $58.3 \mathrm{~Hz}$, and returned to normal in 2.5 hours. The electrical disturbance on the grid resulted in a reactor trip at Unit 1, when its reactor coolant pumps (RCPs) tripped on undervoltage, and a trip occurred at Unit 2 reactor when two of four RCPs tripped.

Palo Verde is in the southern island where the frequency initially spiked to $61.3 \mathrm{~Hz}$, dropped to $58.5 \mathrm{~Hz}$, and returned to normal in 70 minutes. Palo Verde Unit 1 and Unit 3 reactors tripped due to a substantial load decrease concurrent with a significant load demand increase that exceeded the variable over power trip (VOPT) setpoint. Unit 2 did not reach the VOPT setpoint.

Frequency oscillations on the transmission lines San Onofre $1 \& 2$ and WNP-2 were not large enough to cause the units to trip.

On March 19, 1997, while Units 1 and 2 were at 100 percent power, both units experienced simultaneous reactor trips following a grid disturbance. A fault on a remote $345 \mathrm{kV}$ transmission line for which the primary protective relaying was out of service resulted in shedding various loads through opening of transmission line circuit breakers. Eight circuit breakers opened in the Beaver Valley Switchyard. Beaver Valley Unit 1 and 2 reactors tripped after the Unit 1 and 2 generator $345 \mathrm{kV}$ output breakers opened due to inadvertent operation of a breaker failure and its backup timer relays on the \#3 $345 \mathrm{kV}$ bus in response to the disturbance.

LER 352/95-002 On February 21, 1995, while Units 1 \& 2 were at 100 percent power, a $220 \mathrm{kV}$ transmission line to Limerick tripped following a fault on the grid. A circuit breaker at an offsite substation failed, causing a voltage spike that faulted a lightning arrester. Several other transmission lines tripped as a result of the fault. The $220 \mathrm{kV}$ transmission line isolated and returned to service, but not before Unit 1 and 2 main transformer relays initiated Unit 1 and 2 generator and reactor trips. 
The Fukushima accident identified the following potential multi-unit IEs that have not been cited previously:

- Radiological consequences from a damaged unit or damaged waste storage vessels/structures may affect the safety (and recovery actions) of other units.

- Accident response resource limitations and errors can hinder recovery at one unit, which may initiate IEs at colocated units (movement of flammable or explosive substances from a damaged unit, competing resource demands between the reactor and the SFP, etc.).

- A normally isolated connection between units may fail because of an external hazard (e.g., a seismic event).

- An unforeseen or unplanned connection between plant compartments or buildings may exist or may be caused by an external hazard.

- Multi-unit IEs also need to consider and identify IEs for shutdown units, even if prematurely shutdown.

- External events may be correlated (e.g., seismically induced tsunami, flood, fire)

The event at Fukushima shows that all equipment/components that contain radiological or nonradiological sources should be considered when identifying multi-unit IEs. Shared systems also need to be considered as potential multi-unit IEs, and as shown by the Fukushima event, the shared systems to be reviewed include more than just fluid systems. 


\section{NRC/INDUSTRY EFFORTS}

\subsection{GENERIC SAFETY ISSUES}

The NRC's Generic Issue Program was reviewed to identify safety issues that may affect more than one unit at a site. According to the NRC, "A Generic Issue is a well-defined, discrete, technical or security issue, the risk/or safety significance of which can be adequately determined, and which ... applies to two or more facilities. .." The following generic safety issues (GSIs) were selected for further review based on their potential for identifying couplings between units at multi-unit sites. Appendix E provides a description of the individual GSIs.

- GSI 43, Reliability of Air Systems

- GSI 44, Failure of Saltwater Cooling System (Rev. 1)

- GSI 45, Inoperability of Instrumentation due to Cold Weather

- GSI 102, Human Error Wrong Unit or Wrong Train

- GSI 130, ESW pump failures at Multiplant Sites

- GSI 143, Availability of Chilled Water Systems and Room Cooling

- GSI 153, Loss of Essential Service Water in LWRs

- GSI 156, Systematic Evaluation Program (SEP)

- GSI 162, Inadequate Tech Specs at Multiplant Sites

- GSI Item A-17 (Three Mile Island [TMI] Action Plan), Systems Interactions

- GSI A-44, Station Blackout

- COL-ISG-022, ISG on impact of construction (ML112630044)

- Candidate GSI, multi-unit damage events

NRC's GSIs were reviewed because numerous GSIs specifically address or are applicable to multiunit interactions, with the events themselves potentially not reported through the licensee event reporting system. For example, a candidate GSI on multi-unit core damage events states that: [36]

... multiple unit core damage scenarios generally result from an initiator that can fail similar equipment in each unit (e.g., a seismic event or an internal flooding event) or are a result of a high degree of sharing of systems among the units (e.g., sharing all diesel generators). A complete set of potential multi-unit IEs is a necessary step in advancing industry's knowledge in support of riskinformed decision making. To understand the contribution of multi-unit and non-reactor effects to the overall site risk, PRA models need to be enhanced to address, among other items, the following:

- Initiating events common to multiple reactors and/or spent fuel pools and dry casks

- Common or dependent equipment and operator actions between multiple reactors and/or spent fuel pools and dry casks

The overarching theme of GSIs with respect to multi-units is the sharing of systems such as air systems, external events such as environmental effects, or proximity events such as construction. Some GSIs provide insights into multi-unit IEs that are not typically addressed in PRAs. A brief discussion of the more insightful GSIs is discussed below.

An example of a GSI of interest to multi-unit IEs is GSI Issue 102, "Human Error in Events Involving Wrong Unit or Wrong Train." GSI 102 is of interest because while one unit has a failure, and human actions caused a similar failure at the other unit.

Human errors in maintenance and testing operations can be major contributors to "loss of safety system" events. Safety functions can be inadvertently defeated by human errors involving the wrong unit, wrong train, or wrong system. 
Because the procedures are most likely to be the same for each unit at a multi-unit site, a flawed procedure would also be the same for each unit. However, for this to be an IE, the flawed procedure would have to be implemented at the same time on both units; in GSI 102, the NRC deemed this to be unlikely.

Human performance issues carry significant implications for personnel who will monitor and supervise these operations in modular reactors. A potential human factors engineering (HFE) concern is the stress imposed when single crews are monitoring multiple plants. Operators managing multiple units may encounter additional occasions to make the "wrong unit/train" errors that persistently were noted over the years at dual-unit NPP sites. [37,38] In this instance, the operator causes an IE at the "wrong unit."

GSI 130, "Essential Service Water Pump Failures at Multi-plant Sites," was identified when the staff found the Byron Unit 1 vulnerable to core-melt sequences in the absence of the availability of Byron Unit 2. Although Unit 2 was under construction, a safety evaluation by the licensee determined that the success criteria for the multi-plant configurations with two ESW pumps/plants with crosstie capabilities assumed that one ESW pump can provide adequate cooling to shut down the operating plant through the crosstie connections if the need should arise. However, with only one ESW pump operating, the other three pumps may not be available in sufficient time if the operating pump fails. The results are applicable to one plant in normal operation and the second plant already in the shutdown or refueling mode of operation. Hence, this GSI shows that multi-unit vulnerabilities may exist even when one of the plants is not operational or when it is in a shutdown state.

GSI 162 (similar to GSI 130), identified the potential for additional shared systems to have an inadequate number of available components or inadequate flow rates when one unit is shut down and the other unit is operating. The following systems were identified as having the potential for inadequate TS when they are shared: (1) HVAC systems for shared control room areas and switchgear rooms; (2) onsite ac and dc systems; and (3) the CCW system.

The sharing of the ESFS for a multi-unit plant, including onsite emergency power systems and service systems, can result in a reduction of the number and capacity of onsite systems to below that needed to bring either unit to a safe shutdown condition, or to mitigate the consequences of an accident. Shared systems for multiple unit stations should include equipment powered from each of the units involved.

“. . . it is difficult to identify and adequately treat dependencies that exist between systems at multi-unit sites, particularly those with highly convoluted support system dependencies (systems and subsystems shared by different units)." [39]

GSI 156 shows the importance of including all sources of radiological material, not just the reactors themselves.

GSI Item A-44 did not address dual- or multi-unit coupling of ac power; however, the information was discussed in the references. Insights from this review (including references NUREG-1032 and RG $1.155)$ are that offsite power can be lost to multi-units simultaneously.

Accident sequences have been identified which potentially result in core damage accident sequences occurring in multiple units of a multi-unit site. Multi-unit core damage scenarios generally result from an EI that can fail similar equipment in each unit (e.g., a seismic event or an internal flooding event), or the scenarios result from a high degree of system sharing among units, such as sharing all diesel generators.

During the sequence identification and selection process for the NRC's State-of-the-Art Reactor Consequence Analyses (SOARCA) project for the Surry and Peach Bottom plants, the SOARCA staff members identified scenarios in which both units at each plant would be expected to experience accident sequence progression pathways leading to core damage as a result of the initiating event. [36] These scenarios include internal flooding (turbine building flood), long-term station blackout, and seismicinitiated, long-term station blackout. 
A summary of the insights learned from the GSI review includes:

- CCFs and dependent equipment and operator actions between multiple reactors should be considered as IEs.

- Crossties between units (i.e., shared systems) contribute significantly to lessening risks, but they can also be large contributors to risks such as flooding, LOOP, and seismic events.

- All operating states must be considered; it should not be assumed that both units are in the same operating state.

- Along with the reactor, all sources of radiological material should be considered.

- Some systems may not be available because technical specifications allow more equipment to be inoperable during LPSD conditions than at power.

- By definition, LPSD IEs impact the operable train of decay heat removal systems.

- Human errors are more likely because of the increase in activity during shutdown. Unusual equipment line-ups also make mistakes more likely.

- For multi-unit sites, the proximity of construction and construction-related accidents at one unit increase the likelihood of construction-induced IEs at the other unit, which may be at-power operations or shutdown.

\subsection{REGULATORY GUIDELINES}

The NRC regulatory guides (RGs) were reviewed to identify safety issues that may affect more than one unit at a site. The following RGs were selected for further review based on their potential for identifying links between units at multi-unit sites. Appendix F provides a description of the individual RGs:

- RG 1.32, Criteria for Power Systems for Nuclear Power Plants

- RG 1.81, Shared Electric Systems for Multi-unit NPPs

LOOPs can be cascading events that are simultaneously occurring, or they can be propagating events in which one unit is affected. The RGs selected for review evaluate the sharing of electric power systems between units at multi-unit sites. IEEE Std. 308-2001 (endorsed by RG 1.32, except for the sharing of dc power systems) states that shared Class $1 \mathrm{E}$ (safety-related) power systems are permissible in multi-unit stations provided that certain rigorous conditions for sharing are met. However, RG 1.81 states that dc power systems in multi-unit nuclear power plants should not be shared but should be independent for each unit. Therefore, the NRC does not endorse the IEEE Std. 308-2001 criteria for sharing safety-related dc power systems in multi-unit nuclear power plants.

Conflicting with 10 CFR 50.55a(h) (and IEEE 603-1991), RG 1.81 recommends separate and independent onsite emergency and shutdown electric systems for multi-unit nuclear power plants. It further recommends that onsite emergency electric power systems should not be shared between units and should be independent to minimize undesirable interactions between units. Thus, electrical power systems can be shared between units as long as the shared components follow the guidance in IEEE Std. 3081980, which states that Class $1 \mathrm{E}$ power systems can be shared between units provided that the ability to simultaneously perform required safety functions is not impaired.

As noted under requirements, Section 5.13, "Multi-unit Stations" of IEEE Std. 603-1991 states that "The sharing of structures, systems, and components between units at multi-unit generating stations is permissible provided that the ability to simultaneously perform required safety functions in all units is not impaired." This section further states that the guidance on sharing electrical power systems between units is contained in IEEE Std. 308-1980, and the guidance on the application of the single failure criterion to shared systems is contained in IEEE Std. 379-1988. 
The recommendations of RG 1.81 with respect to dc systems clearly state they should not be shared, and the NRC staff cited this regulatory guidance in discussions with the Department of Energy (DOE) regarding the MHTGR. In response, DOE stated that the MHTGR overall design and safety features are radically different from those of the current light water reactor (LWR) designs and that the four reactors used in the MHTGR design form a single power plant station with respect to power generation and control. In addition, DOE stated that the essential dc power and essential ac uninterruptable power supply (UPS) systems are totally separate and independent of the nonessential dc and UPS power systems used for normal plant control. [40]

The NRC staff members in its draft Safety Evaluation Report for the MHTGR [40] agreed with the power-supply sharing proposed by DOE for the conceptual design:

The staff members believe it likely that the conceptual DOE position can be supported because the MHTGR places so little reliance on power supplies for ensuring plant safety, and because any advantages of having a greater number of power supplies can be outweighed by the advantages involving easier maintenance and surveillance with an overall plant system limited to four essential dc and UPS systems.

IEEE Std. 379-2000 (endorsed by RG 1.53) provides acceptable methods for satisfying the NRC's regulations with respect to the application of the single-failure criterion to the electrical power, instrumentation, and control portions of nuclear power plant safety systems. IEEE Std. 379-2000 defines shared systems as [41]

Structures, systems, and components that can perform functions for more than one unit in multiunit stations.

This definition includes the following:

a. systems that are simultaneously shared by both units,

b. time sequential sharing or systems that would be shared by two units at different times, according to the sequence of events, and

c. systems that would only be used by one unit, at any given time, but that could be disconnected from that unit and placed in the other unit on demand.

IEEE Std. 379-2000 also addresses shared systems in its definition of the single-failure criterion. The single-failure criterion is applied to units with shared systems as follows: [41]

a. The safety systems of all units shall be capable of performing their required safety functions with a single failure assumed within the shared systems or within the auxiliary supporting features or other systems with which the shared systems interface.

b. The safety systems of each unit shall be capable of performing their required safety functions, with a single failure initiated concurrently in each unit within the systems that are not shared.

Provisions shall be included in the design to ensure that single failures within one unit will not adversely affect (propagate to) the other unit, thereby preventing the shared systems from performing the required safety functions.

The failures in criteria (a) and (b) need not be considered simultaneously in the performance of the single-failure analysis. That is, the single-failure analysis is conducted for the plant to demonstrate that criterion (a) is met, and then the single-failure analysis is repeated to demonstrate that criterion (b) is met. [41]

Based on a review of the RGs, the following insights were noted: 
- When reviewing shared systems, ac electric power systems can be shared between units, and

- dc electric power systems should not be shared, but a review of IEs should include this for completeness.

\subsection{OTHER NRC STUDIES}

Other NRC studies were reviewed to identify safety issues that may affect more than one unit at a site. The following NUREGs were selected for further review based on their potential for identifying links between units at multi-unit sites. Appendix G provides a description of the individual NUREGs.

- NUREG/CP-0149, Vol. 2: Proceedings of the U.S. Nuclear Regulatory Commission Twenty-Third Water Reactor Safety Information Meeting

- NUREG-1843, Safety Evaluation Report Related to the License Renewal of the Browns Ferry Nuclear Plant, Units 1, 2, and 3

- NUREG/CR-6890, Vol. 1, Reevaluation of Station Blackout Risk at Nuclear Power Plants Analysis of Loss of Offsite Power Events: 1986-2004

- NUREG/CR-5750, Rates of Initiating Events at U.S. Nuclear Power Plants: 1987-1995

Many plants can crosstie at least a few important systems. Crossties allow failures within systems to be circumvented. The crossties can be fairly simple connections among parallel trains of a system or complex connections among different units of a multi-unit site. Crossties typically involve systems such as electric power, auxiliary feedwater, service water, and various water storage tanks.

It is difficult to identify and adequately treat dependencies that exist between systems at multi-unit sites, particularly those with highly convoluted support system dependencies in which systems and subsystems are shared by different units. There are IEs that may or may not impact two or more units at the same site, human action dependencies in deciding how to deploy equipment and personnel to support all plants on the site, and the possibility of accidents involving two or more reactors.

Among the 135 LOOP events identified between 1986-2004, [42] there were 12 occurrences involving more than one plant at a site, eleven of which involved both plants at dual-plant sites, while one (Palo Verde on June 14, 2004) involved all three plants at the site.

Conditional probabilities of other plants at a multi-plant site experiencing a LOOP, given a LOOP at the plant being analyzed, range from $6.0 \mathrm{E}-2$ for plant-centered LOOPs to $8.2 \mathrm{E}-1$ for grid-related LOOPs. Because all of the 12 events identified in the review affected all plants at a site, the probabilities are considered to apply to all other plants at the site. For example, if a site has three plants and one plant experiences a grid-related LOOP while at power, then the probability that the other two plants will also experience the same grid-related LOOP is $8.2 \mathrm{E}-1$. In the broader scope, this is important because grid disturbances are not selected as IEs, whereas LOOPs are.

A previous review of IEs (not specific to multi-unit IEs) identified twelve cases in the 1987-1995 time period in which two reactors at a common site tripped simultaneously due to a related cause. [43] This frequency equates to an expectation across the industry of about one dual-unit trip per year. In that review, only one dual-unit reactor trip was not related to an electrical disturbance or loss of offsite power. The electrical problems were caused by an electrical fault in the plant switchyard or site transmission line that affected both units simultaneously, or they were caused by an electrical fault in one unit that propagated to the neighboring unit through a common or connected switchyard. Three of these dual-unit trip events were related to voltage surges caused by lightning strikes to the plant that resulted in multiple control rods to drop into the core. One other dual-unit trip event was caused by manual reactor trips of both reactors due to the loss of the common station air system.

Twelve cases were identified in the 1987-1995 time period in which two reactors at a common site tripped simultaneously due to a related cause. These occurrences equate to an expectation across the industry of about one dual-unit trip per year. Only one dual-unit reactor trip was not related to an 
electrical disturbance or loss of offsite power. The electrical problems were caused by an electrical fault in the plant switchyard or site transmission line that affected both units simultaneously, or by an electrical fault in one unit that propagated to the neighboring unit through a common or connected switchyard. Three of these dual-unit trip events were related to voltage surges caused by lightning strikes to the plant that caused multiple control rods to drop into the core. One other dual-unit trip event was caused by manual reactor trips of both reactors due to the loss of the common station air system. [43]

Multi-unit trips are relatively rare events. A majority of dual-unit reactor trips are LOOP related, like the great northeast blackout in August 2003. Table 5 lists the dual reactor trip events that occurred during the 1987-1995 time frame. [43]

Table 5. Summary of dual unit reactor trips based on all operating experience from 1987-1995 [NUREG/CR-5750]

\begin{tabular}{lll}
\hline \multicolumn{1}{c}{ Plants } & \multicolumn{1}{c}{ LER No. } & \multicolumn{1}{c}{ Initial Plant Fault } \\
\hline Diablo Canyon 1, & $275 / 94-020$ & Loss of primary flow (reactor protection system [RPS] trip) \\
Surry 1, 2 & $280 / 90-004$ & Manual reactor trip \\
Calvert Cliffs 1, 2 & $317 / 87-012$ & Loss of offsite power \\
Calvert Cliffs 1, 2 & $317 / 93-003$ & Loss of nonsafety-related bus/loss of primary flow (RPS trip) \\
Sequoyah 1, 2 & $327 / 92-027$ & Loss of offsite power \\
Beaver Valley 1, & $334 / 94-005$ & Loss of primary flow (RPS trip)/fire \\
Limerick 1, 2 & $352 / 95-002$ & Turbine trip \\
Vogtle 1, 2 & $424 / 95-002$ & Spurious reactor trip \\
Comanche Peak 1,2 & $445 / 95-002$ & Reactivity control imbalance \\
Braidwood 1,2 & $456 / 88-025$ & Loss of instrument or control air system \\
Braidwood 1,2 & $456 / 89-006$ & Reactivity control imbalance \\
Palo Verde 1, 3 & $528 / 91-010$ & Core power excursion (RPS trip) \\
\hline
\end{tabular}

Insights gained from the review of other NRC studies include:

- Properly designed crossties between systems can substantially decrease the CDF.

- The potential for incorrect cross connecting exists.

- Cross-connections may exist not only between units but with the fuel pool cooling system

- Grid disturbances can not only cause LOOPs, but plant transient even if offsite power remains available.

\subsection{INTERNATIONAL STUDIES RELATED TO MULTI-UNIT IES}

International studies related to multi-unit IEs were reviewed to identify safety issues that may affect more than one unit at a site. The following international studies were selected for further review based on their potential for identifying couplings between units at multi-unit sites. Appendix $\mathrm{H}$ provides a description of the individual studies.

- IAEA Safety Series Report 25, Review of Probabilistic Safety Assessments by Regulatory Bodies

- Committee on the Safety of Nuclear Installations (CSNI) Technical Opinion Paper No. 16, Defence in Depth of Electrical Systems

NRC Information Notice (IN) 2005-15, "Three-Unit Trip and Loss of Offsite Power at Palo Verde Nuclear Generating Station," and IN 2007-14, "Loss of Offsite Power and Dual-unit Trip at Catawba Nuclear Generating Station," discuss two events in which an electrical fault at a significant distance from an NPP caused a multi-unit trip and loss of all offsite power. In each case, one of the units at a multi-unit 
plant encountered a problem with one of its emergency diesel generators. These examples illustrate that external faults located at a significant distance from the plant have been the cause of several plant trips and/or losses of offsite power. Such instances pose challenges to control room operations. The substation serving the NPP has a significant influence in plant trips and the availability of offsite power. While a plant trip may accrue a significant loss of revenue, the loss of offsite power has far more significant nuclear safety implications because the plants rely on offsite power as the preferred source of power for emergency core cooling.

Insights gained from the review of international studies related to multi-unit IEs include:

- The set of IEs should include events of very low frequency (e.g., rupture of the reactor pressure vessel).

- Potential radiological consequences should also be included.

- IEs that can affect multiple units (e.g., loss of grid power and most external events) should be properly identified and should take account of the shared systems which are required by both/all of the units (instead of being fully available for one unit).

- Missiles from turbine disintegration could strike a vulnerable part of another unit, an event that needs to be identified, even though it may be screened out later after analysis.

- Interconnections between units could lead to an accident in one unit, giving rise to an IE in another unit.

- The set of IEs should be compared with those for similar plants to ensure that any other relevant IEs have been included.

- A review of the NPP operating experience and of similar NPPs should be conducted to ensure that any IEs that have actually occurred are included in the set of IEs.

- External faults on the grid located at a significant distance from a plant must be considered, as they have been the cause of several plant trips and/or LOOPs.

Dual-unit events impact not only the potential source terms, but also the potential effectiveness and the potential for successful implementation of mitigating measures since the plant staff would be required to address accidents in both units simultaneously. Thus, events not mitigated could propagate to an unaffected unit. In addition, mitigating measures must be correctly addressed in the recovery probabilities. 



\section{CONCLUSIONS}

The licensing basis for the current fleet of NPPs does not require a site-wide evaluation of risk because each NPP in the US has a separate license. Because of the increased sharing of systems and close proximity of units, the modular design of the AdvSMR increases the likelihood that IEs at a single reactor unit will affect another reactor or reactor module. Thus, the increased level of interactions requires a sitewide assessment of risk, which means that the PRAs for modular reactor designs must specifically address the increased interactions and dependencies. If the sharing of systems and close proximity of units are not properly assessed, the probabilistic and safety assessments will underestimate site risk and improperly identify risk drivers. To overcome this deficiency, comprehensive lists of multi-unit IEs and guidance on modeling multi-unit accident scenarios are essential.

The understanding of risk at multi-reactor plant sites is important. Studies show an increased level of risk or different risk drivers because of multiple units on a site. For example, the multi-reactor plant PRA for the Browns Ferry Nuclear Plant estimated a CDF for the site that was four times greater than that for Unit 2 alone. A risk assessment for Brunswick shows that the dual-unit SBO accounts for 37 percent of the total CDF compared with only 2.3 percent from single-unit SBO. These studies show that the risk drivers for single-unit sites are significantly different than those for multi-unit sites.

Selecting a complete and representative set of IEs is one of the most important tasks for determining risk. No guidance, other than the statement "evaluate multi-unit risk," is available for how to determine the risk at multi-unit sites. In addition, the post-Fukushima environment will require an assessment and understanding of the multi-unit site risk. To properly assess the risk and identify the risk drivers at multi-unit sites, the licensing basis must assess the risk from accidents that could affect multiple units.

The NRC approach for evaluating accidents is based on the deterministic selection of IEs. [6, 7] However, because the risks and risk drivers vary significantly for multi-unit sites compared to single-unit sites, and the limited insights provided in the review of existing multi-unit PRAs, the types of documents reviewed for insights into possible multi-unit interactions were expanded. That is, selecting potential multi-unit IEs the same as had been done previously would lead to an incomplete and misleading set of initiators. The following approach was used to identify types of multi-unit IEs:

- A list of the types of multi-unit IEs to be considered was developed based on a review of multi-unit PRAs. This list was supplemented with insights from operating experience, NRC and industry studies, and ongoing research on calculating source terms for Level 3 PRAs at multi-unit sites.

- External events were chosen deterministically based on single- and multi-unit studies, and based on the event at Fukushima, which included expanding the external events examined to include combined effects events.

- Combinations of all operating modes and sources of radioactive materials must be addressed once designs mature sufficiently.

This process, summarized in Fig. 2, shows that development of a complete and sufficient list of multiunit IEs requires input from numerous diverse sources. No single source adequately identifies potential interactions between units at multi-unit sites. 


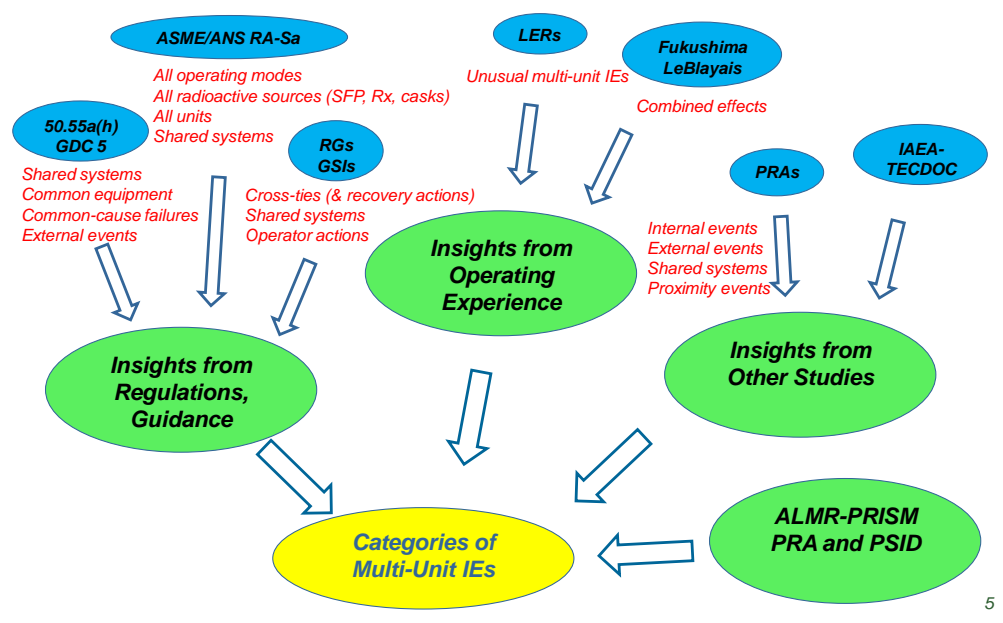

Fig. 2. Sources used to identify multi-unit IEs.

The single- and multi-unit PRAs reviewed only identify a subset of IEs necessary to properly evaluate interactions between units. Focusing on shared system interactions and dependencies between units is a simple solution to a difficult problem. The use of master logic diagrams (MLDs) or Failure Modes and Effects Analyses (FMEAs) to identify multi-unit IEs will capture fluid and electrical system relationships but will miss the subtle dependences. For example, this approach would exclude grid disturbance in which the grid remains powered and the unit(s) may or may not isolate from the grid. The importance of including a grid disturbance in the types of IEs to be considered is that the disturbance may cause a transient or a LOOP, and the response from each unit may be different. For example, one unit may experience a transient while the other unit experiences a LOOP. In addition, at this stage of a design, it is unknown if the response to a grid disturbance will be the same as a transient response.

Another example of a subtle IE is the loss of the $500 \mathrm{kV}$ bus feeding Unit 2. [44] Unit 2 immediately tripped on low coolant flow. Unit 1 was manually tripped by operators in anticipation of a total loss of offsite power. The decision to trip Unit 1 resulted from the conclusion that a loss of offsite power was eminent; however, Unit 1 would not have tripped on loss of the $500 \mathrm{kV}$ bus. The control room supervisor believed, based on the loss of Control Room lighting and trip of Unit 2, that the plant was in the process of losing power to both units. He did not fully recognize and synthesize all of the available information, which in part was due in part to distractions caused by the automatic shutdown of Unit 2. This is another subtle dependency caused by human error and unlikely to be identified using MLDs or FMEAs.

This review shows that current studies are incomplete because they only address a subset of the problem. This is a function of the insufficient and incomplete list of multi-unit IEs. Table 6 provides a preliminary list of "types" of multi-unit IEs that are not currently addressed in single- or multi-unit PRAs. Prior to developing a multi-unit PRA, practitioners should read the events captured in the Appendices to understand and appreciate the subtle interactions and dependencies that exist at multi-unit sites. These events should be reviewed, even though they may be screened out later in the analysis. 
Table 6. Preliminary list of multi-unit IEs in single- or multi-unit PRAs

\begin{tabular}{|c|c|}
\hline Types of multi-unit IEs & Comments \\
\hline Independent events & Currently addressed \\
\hline Common-cause failures & Addressed in single unit, not multi-unit \\
\hline $\begin{array}{l}\text { Proximity events (e.g., drop of stator cause LOOP at Unit 1, transient } \\
\text { at Unit 2) }\end{array}$ & Primarily limited to external events \\
\hline Shared systems (positive and negative effects) & Typically include positive effects only \\
\hline Cross-ties between/among units (positive and negative effects) & Typically include positive effects only \\
\hline Missiles (e.g., missiles from a turbine disintegration striking a & Not addressed in most of the multi-unit PRAs \\
\hline
\end{tabular}
vulnerable part of another unit)

Cascading events (e.g., loss of UAT at Unit 1 results in loss of CCW, Not addressed in most of the multi-unit PRA which was cross-tied to unit 2; transients at both units)

Propagating event (e.g., electrical fault at Unit 1 caused a grid disturbance, which in-turn caused a trip of Unit 2)

Other external events in addition to seismic, flood, wind, fire (e.g., undervoltage generated in switchyard, not offsite transmission system, caused transients at both units)

Combined effects events including seismically-induced flood, seismically-induced systems interactions, seismic-initiated long term SBO, etc.

Other sources of radiological hazards (e.g., reactors, spent fuel pool, dry cask storage)

Integrated models for all site radiological sources, including consideration of model end-states, risk metrics, and mission times Initiating events common to multiple reactors and/or spent fuel pools Account for all operating states, not just full power (e.g., full power, low power, shutdown, refueling, damaged state, construction)

Combinations of operating states (e.g., full power/full power, full power/shutdown, shutdown/refueling, damaged state, construction)

Operators managing multiple units make wrong/unit wrong/train errors

Human errors in maintenance and testing operations on the wrong unit or wrong train causes loss of safety system and transient event Effects of core damage, radiological release, and mitigation actions on operator response (including control room habitability)

PRA must reflect allowable plant configurations when evaluating IEs. For example, NRC identified inadequate Tech Specs for shared systems when one unit is shutdown and the other is operating. (GSI 130, GSI 162)

Shared stacks, ventilation systems, or other pathways for combustible gases

Integrated uncertainty analysis for overall site risk

LOOP events (grid disturbance need not occur close to the plant)

Grid disturbances that may or may not lead to a LOOP or transient event

Evaluate the potential hazards from constructing new plants (COLISG-022)
Not addressed in most of the multi-unit PRA

Not addressed in most of the multi-unit PRA

Not addressed

Addressed in single unit, not multi-unit

Not addressed

Not addressed

Addressed in single unit, not multi-unit

Typically not addressed in multi-unit PRAs

Not addressed

Not addressed

Not addressed

Not addressed

Not addressed

Not addressed

Addressed in single- and multi-unit PRAs

Not addressed

Not addressed 
Using the initial set of multi-reactor plant site initiators, future efforts will evaluate the accident sequences and modeling alternatives for a selected set of initiators. More specifically, the evaluation will compare (1) addressing units individually with dependencies evaluated at the event tree level or the fault tree level to (2) a multi-reactor plant IE affecting 1,2, or 3 reactors simultaneously. The alternatives will be evaluated by modeling accident sequences for a subset of the multi-reactor plant IEs for comparison.

A benefit of evaluating modelling options will be to provide insights on

- Impact on the success criteria for an individual system or group of systems, and

- Change in the frequencies of IEs previously considered (i.e., the frequency of occurrence is affected by multi-reactor plant operation). 


\section{REFERENCES}

1. NUREG-1437 (Appendix G) for Brunswick Units 1 and 2 (USNRC 2006).

2. INPO 11-005 Addendum, Lessons Learned from the Nuclear Accident at the Fukushima Dai-ichi Nuclear Power Station, August 2012.

3. PRA for the Browns Ferry Nuclear Plant.

4. K. N. Fleming, Application of Probabilistic Risk Assessment to Multi-Unit Sites, Presented to the National Academy of Sciences Fukushima Committee, June 24, 2013.

5. SECY-2013-0112, Consequence Study of a Beyond-Design-Basis Earthquake Affecting the Spent Fuel Pool for a U.S. Mark I Boiling-Water Reactor

6. Letter from J. M. Taylor, Executive Director for Operations, to the Commissioners, transmitting SECY-93-092, "Subject: Issues Pertaining to the Advanced Reactor (PRISM, MHTGR, and PIUS) and Candu 3 Designs and their Relationship to Current Regulatory Requirements," April 8, 1993.

7. Safety Requirements Memorandum (SRM), "Subject: SECY-93-092, "Subject: Issues Pertaining to the Advanced Reactor (PRISM, MHTGR, and PIUS) and Candu 3 Designs and their Relationship to Current Regulatory Requirements," U.S. Nuclear Regulatory Commission, July 30, 1993.

8. Letter from W. D. Travers, Executive Director for Operations, to the Commission, transmitting SECY-03-0047, "Subject: Policy Issues Related to Licensing Non-Light-Water Reactor Designs," March 28, 2003.

9. NUREG/CR-6042, Perspective on Reactor Safety.

10. COL-ISG-022, Interim Staff Guidance on Impact of Construction (under a Combined License) of New Nuclear Power Plant Units on Operating Units at Multi-unit Sites.

11. ASME/ANS RA-Sa-2009, Addenda to ASME/ANS RA-S-2008 Standard for Level 1/Large Early Release Frequency Probabilistic Risk Assessment for Nuclear Power Plant Applications, 2009.

12. IAEA Safety Standards Series No. NS-R-1, Safety of Nuclear Power Plants: Design Safety Requirements.

13. IAEA Safety Standards Series No. Ns-G-1.2, Safety Assessment and Verification for Nuclear Power Plants Safety Guide.

14. SECY-11-0089, Options for Proceeding with Future Level 3 Probabilistic Risk Assessment Activities.

15. Letter from Greg Gibbs, Project Director Next Generation Nuclear Plant Project to U.S. NRC, transmitting "Contract No. DE-AC07-05 ID 14517 - Next Generation Nuclear Plant Project Submittal Response to Nuclear Regulatory Commission Request for Additional Information Letter No. 005 Regarding the Risk-Informed, Performance-Based Licensing Approach - NRC Project \#0748," October 14, 2011. (Adams Accession No. ML11290A188).

16. Pebble Bed Modular Reactor (Proprietary) Ltd., "PBMR Preapplication Meeting," October 27, 2006. (Adams Accession No. ML070260042).

17. U.S. NRC, "Scoping Estimates of Multiunit Nuclear Power Plant Site Risks" (Adams Accession No. ML13255A371).

18. SECY-13-0112, Consequence Study of a Beyond-Design-Basis Earthquake Affecting the Spent Fuel Pool for a U.S. Mark I Boiling-Water Reactor.

19. Regulatory Background on Multi-unit Risk (ML13255A370). 
20. SECY-12-0095, Tier 3 Program Plans and 6-Month Status Update In Response to Lessons Learned from Japan's March 11, 2011, Great Tohoku Earthquake and Subsequent Tsunami.

21. Advisory Committee on Reactor Safeguards Reliability and Probabilistic Risk Assessment, February 19, 2014.

22. US Nuclear Regulatory Commission, "Resolution of Generic Safety Issues: Issue 172: Multiple System Responses Program (Rev. 2)," NUREG-0933, Main Report with Supplements 1-34.

23. Advisory Committee on Reactor Safeguards Reliability and PRA Subcommittee, March 5, 2014.

24. 2692007001R01 Oconee 1 and 2

25. 5281991010R00 Palo Verde 1 and 3.

26. 5281996004R00 Palo Verde 1 and 3.

27. 2592011001R00 BNFP 1, 2, and 3.

28. 5282004006R01 Palo Verde 1, 2, and 3.

29. Regulatory Background on Multi-unit Risk (ML13255A370).

30. Open Item OI-SRP10.2.3-CIB1-01 http://pbadupws.nrc.gov/docs/ML1009/ML100910522.pdf

31. International Atomic Energy Agency, "International Workshop on the Safety of Multi-Unit Nuclear Power Plant Sites against External Natural Hazards," Anushakti Nagar, Mumbai, India, October 1719, 2012. http://www-pub.iaea.org/iaeameetings/44399/International-Workshop-on-the-Safety-ofMulti-Unit-Nuclear-Power-Plant-Sites-against-External-Natural-Hazards.

32. NUREG-1784, Operating Experience Assessment - Effects of Grid Events on Nuclear Power Plant Performance.

33. B. J. Garrick, study director, Seabrook Station Probabilistic Safety Assessment, Main Report, PLG0300, Pickard, Lowe and Garrick, Inc. Irvine, CA, December 1983.

34. Byron and Braidwood Stations Individual Plant Examinations, Commonwealth Edison (CECo), March 1997.

35. General Atomics, Probabilistic Risk Assessment for the Standard Modular High Temperature GasCooled Reactor, DOE-HTGR-86011, Revision 5, April 1988.

36. Candidate Generic Issue - Multi-Unit Core Damage Events, circa 2007-2008.

37. NUREG/CR-7126, Human-Performance Issues Related to the Design and Operation of Small Modular Reactors.

38. O'Hara, J., Higgins, J., Brown, W. \& Fink, R. (2008). Human Factors Considerations with Respect to Emerging Technology in Nuclear Power Plants: Detailed Analyses (BNL Technical Report No: 79947-2008). Upton, NY: Brookhaven National Laboratory.

39. K. N. Fleming, Issues and Recommendations for Advancement of PRA Technology in Risk-Informed Decision Making, NUREG/CR-6813, U.S. NRC, April 2003.

40. NUREG-1338, Draft Preapplication Safety Evaluation Report for the Modular High-Temperature Gas-Cooled Reactor.

41. IEEE 379-2000, IEEE Standard Application of the Single-Failure Criterion to Nuclear Power Generating Station Safety Systems (endorsed by RG 1.53).

42. NUREG/CR-6890, Vol. 1, Reevaluation of Station Blackout Risk at Nuclear Power Plants Analysis of Loss of Offsite Power Events: 1986-2004. 
43. J. P. Poloski, D. O. Marksberry, C. L. Atwood, and W. J. Galyean, Rates of Initiating Events at U.S. Nuclear Power Plants: 1987 - 1995, NUREG/CR-5750, Idaho National Engineering and Environmental Laboratory, February 1999.

44. 317/1993-003, Calvert Cliffs 1, "Dual Unit Trip Due To Partial Loss of Offsite Power," July 9, 1993. 

APPENDIX A. SYSTEMS IN PRISM 



\section{Systems in PRISM}

(A plant consists of 3 power blocks with 3 reactor modules [NSSS Systems]/power block.)

\begin{tabular}{|c|c|c|}
\hline System Name & $\begin{array}{l}\text { Common System } \\
\text { Between Modules }\end{array}$ & $\begin{array}{c}\text { Plant-Wide } \\
\text { Shared System }\end{array}$ \\
\hline Primary Heat Transport System & - & - \\
\hline Intermediate Heat Transport System & - & - \\
\hline Sodium-Water Reaction Pressure Relief Subsystem (IHTS) & - & - \\
\hline $\begin{array}{l}\text { Steam Generator and Water/Steam Subsystem (Steam Generator } \\
\text { System) }\end{array}$ & $\mathrm{X}$ & - \\
\hline Leak Detection Subsystem (Steam Generator System) & $\mathrm{X}$ & - \\
\hline Water Dump Subsystem (Steam Generator System) & $\mathrm{X}$ & - \\
\hline Auxiliary Cooling Subsystem (Steam Generator System) & $\mathrm{X}$ & - \\
\hline $\begin{array}{l}\text { Reactor Vessel Auxiliary Cooling System (Shutdown Heat Removal } \\
\text { Systems) }\end{array}$ & - & - \\
\hline Auxiliary Cooling System (Shutdown Heat Removal Systems) & - & - \\
\hline Containment Systems & - & - \\
\hline Plant Control System (PCS) & $\mathrm{X}$ & $\mathrm{X}$ \\
\hline Power Block Control System & $\mathrm{X}$ & - \\
\hline Module Control System & - & - \\
\hline Local Control System & - & - \\
\hline Reactor Protection System (RPS) & - & - \\
\hline Radiation Monitoring System (I\&C) & $\mathrm{X}$ & $\mathrm{X}$ \\
\hline Fire Protection Monitoring (I\&C) & $\mathrm{X}$ & $\mathrm{X}$ \\
\hline Impurity Monitoring System & $\mathrm{X}$ & $\mathrm{X}$ \\
\hline Refueling Neutron Flux Monitor (I\&C) & - & - \\
\hline Diagnostic Monitoring (I\&C) & - & - \\
\hline Loose Parts Monitoring (LPM) (I\&C) & - & - \\
\hline Data Handling and Transmission System (DHTS) & $\mathrm{X}$ & $\mathrm{X}$ \\
\hline Plant Control Complex (includes MMI) & $\mathrm{X}$ & $\mathrm{X}$ \\
\hline Preferred Offsite Power System (unit aux power system) & $\mathrm{X}$ & $\mathrm{X}$ \\
\hline Secondary Offsite Power System (common station service system) & $\mathrm{X}$ & $\mathrm{X}$ \\
\hline Onsite AC Power System & $\mathrm{X}$ & $\mathrm{X}$ \\
\hline Essential $120 \mathrm{~V}$ ac power & $\mathrm{X}$ & - \\
\hline Onsite DC Power System & $\mathrm{X}$ & - \\
\hline Uninterruptable Power Supply (UPS) systems & $\mathrm{X}$ & - \\
\hline Electromagnetic Pumps Power Supply & - & - \\
\hline Reactor Fuel Handling System (Reactor Refueling System) & $\mathrm{X}$ & - \\
\hline In-Vessel Transfer Machine (IVTM) (Reactor Fuel Handling System) & - & - \\
\hline $\begin{array}{l}\text { Fuel Receiving, Storage and Shipping System (Reactor Refueling } \\
\text { System) }\end{array}$ & - & $\mathrm{X}$ \\
\hline Refueling Enclosure (Transport System) (Reactor Refueling System) & - & $\mathrm{X}$ \\
\hline Fuel Transfer Cask (Transport System) (Reactor Refueling System) & - & $\mathrm{X}$ \\
\hline Cask Transporter (Transport System) (Reactor Refueling System) & - & $\mathrm{X}$ \\
\hline Overall Refueling Control System & - & $\mathrm{X}$ \\
\hline Plant Service Water System & - & $\mathrm{X}$ \\
\hline Turbine Plant Component Cooling Water System & $\mathrm{X}$ & - \\
\hline Chilled Water System & - & $\mathrm{X}$ \\
\hline
\end{tabular}




\section{Systems in PRISM}

(A plant consists of 3 power blocks with 3 reactor modules [NSSS Systems]/power block.)

\begin{tabular}{|c|c|c|}
\hline System Name & $\begin{array}{l}\text { Common System } \\
\text { Between Modules }\end{array}$ & $\begin{array}{c}\text { Plant-Wide } \\
\text { Shared System }\end{array}$ \\
\hline Makeup Water Treatment Subsystem (Treated Water System) & - & $\mathrm{X}$ \\
\hline $\begin{array}{l}\text { Steam Generator Blowdown Cleanup Subsystem (Treated Water } \\
\text { System) }\end{array}$ & - & $\mathrm{X}$ \\
\hline Potable Water Subsystem (Treated Water System) & - & $\mathrm{X}$ \\
\hline Chemical Feed Subsystem (Treated Water System) & - & $\mathrm{X}$ \\
\hline $\begin{array}{l}\text { Water Source System (water to cooling tower basins; raw water } \\
\text { supply) }\end{array}$ & - & $X$ \\
\hline Waste Water Disposal Subsystem (Wastewater Treatment System) & - & $\mathrm{X}$ \\
\hline Sanitary Waste Disposal Subsystem (Wastewater Treatment System) & - & $\mathrm{X}$ \\
\hline $\begin{array}{l}\text { Inert Gas Receiving and Processing System (IGRPS) (He, Ar, N } \\
\text { Subsystems) }\end{array}$ & - & $\mathrm{X}$ \\
\hline Impurity Monitoring and Analysis System & $\mathrm{X}$ & $\mathrm{X}$ \\
\hline Compressed Air Systems (service air, instrument air) & - & $\mathrm{X}$ \\
\hline Plant Heating, Ventilation, Air Conditioning Systems (HVAC) & - & $\mathrm{X}$ \\
\hline $\begin{array}{l}\text { Sodium Receiving and Transfer Subsystem (Auxiliary Liquid Metal } \\
\text { System) }\end{array}$ & - & $\mathrm{X}$ \\
\hline $\begin{array}{l}\text { Intermediate Sodium Processing Subsystem (ISPS) (Auxiliary Liquid } \\
\text { Metal System) (also called Purification System) }\end{array}$ & - & $\mathrm{X}$ \\
\hline $\begin{array}{l}\text { Primary Sodium Processing Subsystem (PSPS) (Auxiliary Liquid } \\
\text { Metal System) (also called Purification System) }\end{array}$ & - & - \\
\hline Piping and Equipment Heating and Insulation System & - & $\mathrm{X}$ \\
\hline Plant Fire Protection System ( $\mathrm{Na}$ and non-Na fire protection) & - & $\mathrm{X}$ \\
\hline Communication System & - & $\mathrm{X}$ \\
\hline Turbine-Generator & $\mathrm{X}$ & - \\
\hline Main Steam System & $\mathrm{X}$ & - \\
\hline Main Dump System & $\mathrm{X}$ & - \\
\hline Extraction Steam System & $\mathrm{X}$ & - \\
\hline Auxiliary Steam System & - & $\mathrm{X}$ \\
\hline Main Condenser Subsystem (Heat Rejection System) & $\mathrm{X}$ & - \\
\hline Condenser Air Extraction Subsystem (Heat Rejection System) & $\mathrm{X}$ & - \\
\hline Circulating Water Subsystem (Heat Rejection System) & $\mathrm{X}$ & - \\
\hline Feedwater System & $\mathrm{X}$ & - \\
\hline Condensate System & $\mathrm{X}$ & - \\
\hline Feedwater Heater Drain System & $\mathrm{X}$ & - \\
\hline Auxiliary Boiler Feedwater and Condensate System & - & $\mathrm{X}$ \\
\hline $\begin{array}{l}\text { Intermediate/low Activity Level Liquid System (Liquid Waste } \\
\text { Management Systems) }\end{array}$ & - & $\mathrm{X}$ \\
\hline $\begin{array}{l}\text { Detergent and Decontamination Liquid System (Liquid Waste } \\
\text { Management Systems) }\end{array}$ & - & $\mathrm{X}$ \\
\hline Gaseous Waste Management Systems & - & $\mathrm{X}$ \\
\hline Portable Helium Gas Supply System (including storage/transfer tank) & - & $\mathrm{X}$ \\
\hline Solid Waste Management System & - & $\mathrm{X}$ \\
\hline
\end{tabular}




\section{APPENDIX B. MULTI-UNIT SITE STATISTICS}



Table B-1. Multi-unit Site Statistics

\begin{tabular}{|c|c|c|c|c|}
\hline \multirow{2}{*}{$\begin{array}{r}\text { Category } \\
\text { Dual-unit sites }\end{array}$} & \multirow{2}{*}{\begin{tabular}{|l|} 
Number of Sites \\
30
\end{tabular}} & \multicolumn{3}{|c|}{ Notes } \\
\hline & & $\begin{array}{l}\text { Arkansas Nuclear One } \\
\text { (ANO) }\end{array}$ & Dresden & Point Beach \\
\hline & & Beaver Valley & Farley & Prairie Island \\
\hline & & Braidwood & Hatch & Quad Cities \\
\hline & & Brunswick & Indian Point & St. Lucie \\
\hline & & Byron & La Salle & Sequoyah \\
\hline & & Calvert Cliffs & Limerick & South Texas \\
\hline & & Catawba & McGuire & Surry \\
\hline & & Comanche Peak & Millstone & Susquehanna \\
\hline & & D.C. Cook & North Anna & Turkey Point \\
\hline & & Diablo Canyon & Peach Bottom & Vogtle \\
\hline \multirow[t]{3}{*}{ Triple-unit sites } & \multirow[t]{3}{*}{3} & \multicolumn{3}{|l|}{ Browns Ferry } \\
\hline & & \multicolumn{3}{|l|}{ Oconee } \\
\hline & & \multicolumn{3}{|c|}{ Palo Verde } \\
\hline \multirow[t]{2}{*}{ Adjacent sites } & \multirow[t]{2}{*}{2} & \multicolumn{3}{|c|}{ Salem 1\&2 and Hope Creek } \\
\hline & & \multicolumn{3}{|c|}{ Nine Mile Point $1 \& 2$ and FitzPatrick } \\
\hline
\end{tabular}

*These counts exclude the two-unit San Onofre site where both units are being shutdown, the two additional units under construction at the Summer site, and the two additional units under construction at the Vogtle site.

**there are 29 single-unit sites. 

APPENDIX C. OPERATING EXPERIENCE REVIEW FOR MULTIUNIT INITIATING EVENTS 

Table C-1. Multi-unit Initiating Events from 1980-2014

\begin{tabular}{|c|c|c|c|c|c|c|}
\hline Plant & LER No. & IE & Туре 0 & Interaction & $\begin{array}{l}\text { If external, type } \\
\text { correlation }\end{array}$ & Summary of event \\
\hline $\begin{array}{l}\text { Beaver Valley } 1 \text { and } \\
2\end{array}$ & 334/1994-005 & $\begin{array}{l}\text { Cascade event - } \\
\text { electrical fault } \\
\text { at Unit } 1 \text { causes } \\
\text { grid disturbance } \\
\text { which causes } \\
\text { trip at Unit } 2\end{array}$ & Indirect & $\begin{array}{l}\text { Common } \\
\text { off-site } \\
\text { power lines }\end{array}$ & & $\begin{array}{l}\text { An insulating bushing failure on the Unit } 1 \text { Main Unit } \\
\text { Transformer initiated an immediate generator/turbine } \\
\text { trip followed by a subsequent reactor trip. The } \\
\text { transformer fault initiated a voltage disturbance on the } \\
\text { electrical grid which caused an inadvertent protective } \\
\text { relay actuation on a circuit monitoring the } 138 \text { kilovolt } \\
\text { (KV) AC line supplying the Unit } 2 \text { System Station } \\
\text { Service Transformer (SSST) } 2 \mathrm{~A} \text {. Unit } 24 \mathrm{KV} \text { AC busses } \\
\text { were being supplied by the offsite electrical grid. The } \\
\text { loss of the 2A SSST resulted in the actuation of two } \\
\text { reactor coolant pump underfrequency protective relays } \\
\text { on two of the } 4 \mathrm{KV} \text { AC busses. This initiated a Unit } 2 \\
\text { reactor trip. }\end{array}$ \\
\hline LaSalle 1 and 2 & 373/1993-015 & $\begin{array}{l}\text { Cascade event - } \\
\text { loss of UAT at } \\
\text { Unit } 1 \text { results in } \\
\text { loss of } \\
\text { TBCCW, which } \\
\text { was cross-tied } \\
\text { to Unit 2; Unit } 2 \\
\text { lost Station Air } \\
\text { upon loss of } \\
\text { TBCCW }\end{array}$ & Direct & $\begin{array}{l}\text { Shared } \\
\text { system - } \\
\text { TBCCW }\end{array}$ & & $\begin{array}{l}\text { Unit } 1 \text { System Auxiliary Transformer (SAT) } \\
\text { experienced a differential current auto-trip due to water } \\
\text { intrusion in the } 4.1 \mathrm{kV} \text { ductwork and a fast transfer of } \\
\text { loads to the Unit Auxiliary Transformer (UAT) } \\
\text { occurred. The Unit } 1 \text { Station Air (SA) Compressor } \\
\text { tripped as expected. This was also due to momentary } \\
\text { drop in control power voltage. The SAT supplies power } \\
\text { to the station from the grid and the UAT supplies power } \\
\text { to the station from the Main Generator. With the loss of } \\
\text { the SAT due to the fault and the Main Generator trip, } \\
\text { Unit } 1 \text { was in a Loss of Off-site Power (LOOP) } \\
\text { condition. The required second offsite power source to } \\
\text { Unit } 1 \text { was available from the Unit } 2 \text { cross-tie breakers. } \\
\text { LaSalle SAT and UAT provide } 4.1 \mathrm{kV} \text { and } 6.9 \mathrm{kV} \text { for } \\
\text { station loads. The emergency diesel generator (EDG) } \\
\text { and the other Unit only supply } 4.1 \mathrm{kV} \text { power. Therefore, } \\
\text { the } 6.9 \mathrm{kV} \text { busses remained de-energized. The } 6.9 \mathrm{kV} \\
\text { busses supply power to balance-of-plant equipment. } \\
\text { Unit } 2 \text { was in a refueling outage at the time and } \\
\text { receiving power from its SAT which was unaffected by } \\
\text { this transient. Upon the loss of the UAT, the Unit } 2 \\
\text { Station Air Compressor tripped due to the loss of Unit } 1 \\
\text { Turbine Building Closed Cooling Water (TBCCW). } \\
\text { Unit } 1 \text { TBCCW was cross-tied supplying cooling water }\end{array}$ \\
\hline
\end{tabular}


Table C-1. Multi-unit Initiating Events from 1980-2014

\begin{tabular}{|c|c|c|c|c|c|c|}
\hline \multirow[t]{2}{*}{ Plant } & \multirow[t]{2}{*}{ LER No. } & \multirow[t]{2}{*}{ IE } & \multicolumn{2}{|c|}{ Type of Interaction } & \multirow{2}{*}{$\begin{array}{c}\text { If external, type } \\
\text { correlation }\end{array}$} & \multirow[b]{2}{*}{$\begin{array}{l}\text { Summary of event } \\
\text { to the Unit } 2 \text { Station Air Compressor. Unit } 1 \mathrm{TBCCW} \\
\text { Pumps are powered from electrical switchgears which } \\
\text { are supplied from } 6.9 \mathrm{kV} \text { busses. The Unit } 1 \text { and Unit } 0 \\
\text { Station Air Compressors became unavailable because } \\
\text { their control power is supplied by Unit } 16.9 \mathrm{kV} \text { busses. } \\
\text { The actual reactor scram on Unit } 1 \text { was caused by low } \\
\text { (12.5") reactor water level due to the loss of the } 1 \mathrm{~B} \\
\text { TDRFP. The Unit } 1 \text { SAT auto-tripped on differential } \\
\text { current. This was a result of water inleakage into the bus } \\
\text { duct through degraded ductwork joint seals. This } \\
\text { leakage accumulated in a vertical ductwork run to a } \\
\text { surge suppressor compartment in which a sufficient } \\
\text { quantity of water shorted the bus bars. }\end{array}$} \\
\hline & & & & & & \\
\hline Surry 1 and 2 & 280/1990-004 & $\begin{array}{l}\text { Cascade event - } \\
\text { transient at Unit } \\
1 \text { caused } \\
\text { transient at Unit } \\
2\end{array}$ & Indirect & Proximity & & $\begin{array}{l}\text { A fault occurred on the Unit } 1 \text { "A" main transformer as a } \\
\text { result of an inadvertent actuation of the transformer's } \\
\text { deluge system. The fault initiated a Unit } 1 \text { generator } \\
\text { differential lockout which immediately initiated a } \\
\text { turbine trip/reactor trip. The fault also resulted in the } \\
\text { lockout of the "A" (Reserve Station Service Transformer } \\
\text { RSST). Approximately } 10 \text { seconds later, the Unit } 2 \\
\text { control room operator initiated a manual reactor trip } \\
\text { after observing erratic control rod Individual Rod } \\
\text { Position Indications (IRPI). Operators performed the } \\
\text { appropriate plant procedures and quickly stabilized the } \\
\text { units following the trips. The erratic Unit } 2 \text { IRPI } \\
\text { indications were due to voltage transients that occurred } \\
\text { in both units' emergency buses which were caused by } \\
\text { the Unit } 1 \text { generator trip, the "A" RSST lockout, and } \\
\text { subsequent motor starts. The Unit } 2 \text { IRPIs are powered } \\
\text { from the Unit } 2 \text { semi-vital bus, which in turn was } \\
\text { powered from the Unit } 2 \text { "J" emergency bus. The } \\
\text { transformer that supplies power to the IRPIs is designed } \\
\text { to maintain its output voltage with +/- } 0.5 \% \text { when the } \\
\text { input voltage is within +/- } 10 \% \text {. Following the Unit } 1 \\
\text { trip, a voltage transient occurred on both units' } \\
\text { emergency buses due to the fault and subsequent large } \\
\text { motor starts. The voltage transient on the Unit } 2 \text { "J" }\end{array}$ \\
\hline
\end{tabular}


Table C-1. Multi-unit Initiating Events from 1980-2014

\begin{tabular}{|c|c|c|c|c|c|c|}
\hline \multirow[t]{2}{*}{ Plant } & \multirow[t]{2}{*}{ LER No. } & \multirow[t]{2}{*}{ IE } & \multicolumn{2}{|c|}{ Type of Interaction } & \multirow{2}{*}{$\begin{array}{c}\text { If external, type } \\
\text { correlation }\end{array}$} & \multirow{2}{*}{\begin{tabular}{l}
\multicolumn{1}{|c}{ Summary of event } \\
emergency bus exceeded the $+/-10 \%$. This was \\
sufficient to cause significant fluctuations in the IRPIs \\
which prompted the Unit 2 operator to trip the Unit 2 \\
reactor.
\end{tabular}} \\
\hline & & & & & & \\
\hline $\begin{array}{l}\text { Turkey Point } 3 \text { and } \\
4\end{array}$ & $250 / 2008-001$ & $\begin{array}{l}\text { Grid } \\
\text { disturbance }\end{array}$ & Direct & $\begin{array}{l}\text { Shared } \\
\text { system - } \\
\text { switchyard }\end{array}$ & & $\begin{array}{l}\text { A momentary grid voltage disturbance occurred that } \\
\text { caused a reactor trip of both Turkey Point Units } 3 \text { and } \\
4 \text { when both channels of safety-related } 4 \mathrm{KV} \text { bus } \\
\text { undervoltage relays for each unit actuated after a one } \\
\text { second time delay. The grid voltage disturbance } \\
\text { occurred due to human error when a Protection and } \\
\text { Control field engineer disabled both levels of local } \\
\text { protection at an electrical substation which then failed to } \\
\text { actuate when a fault occurred during equipment } \\
\text { troubleshooting. }\end{array}$ \\
\hline Oconee 1 and 2 & 269/2007-001 & $\begin{array}{l}\text { Grid } \\
\text { disturbance }\end{array}$ & Indirect & $\begin{array}{l}\text { Common } \\
\text { off-site } \\
\text { power lines }\end{array}$ & & $\begin{array}{l}\text { An external electrical fault created a grid disturbance in } \\
\text { the } 230 \mathrm{KV} \text { switchyard which serves ONS Units } 1 \text { and } \\
2 \text {. The resulting voltage transient ultimately led to a } \\
\text { reactor trip for both units via the protective relaying. } \\
\text { The initiating event lasted less than one second. A } \\
\text { properly designed protective relaying scheme should } \\
\text { have enabled the units to withstand a switchyard } \\
\text { transient of this magnitude and duration. However, a } \\
\text { wiring design error in the loss-of-excitation relay (40-1) } \\
\text { caused the relay to trip the Unit } 1 \text { and } 2 \text { generators and } \\
\text { turbines through the generator lockout scheme. A latent } \\
\text { design error existed in this relay and its leads were } \\
\text { installed according to this error at initial installation (i.e., } \\
\text { rolled leads). Had this error not been present, testing has } \\
\text { shown that the relay would not have tripped the unit. } \\
\text { The slow bus transfer was caused by incorrect setting of } \\
\text { the fast contacts located on the auxiliary switches on the } \\
\text { Main Feeder Bus Normal Breakers (N-Breakers). This } \\
\text { error has been present since original installation. The } \\
\text { incorrect setting caused the fast contacts to operate } \\
\text { slower than designed. The slower operation of the fast } \\
\text { contacts prevented completion of a fast transfer in less }\end{array}$ \\
\hline
\end{tabular}


Table C-1. Multi-unit Initiating Events from 1980-2014

\begin{tabular}{|c|c|c|c|c|c|c|}
\hline \multirow[t]{2}{*}{ Plant } & \multirow[t]{2}{*}{ LER No. } & \multirow[t]{2}{*}{ IE } & \multicolumn{2}{|c|}{ Type of Interaction } & \multirow{2}{*}{$\begin{array}{c}\text { If external, type } \\
\text { correlation }\end{array}$} & \multirow{2}{*}{$\begin{array}{l}\text { Summary of event } \\
\text { than } 60 \text { milliseconds as designed. }\end{array}$} \\
\hline & & & & & & \\
\hline $\begin{array}{l}\text { Diablo Canyon } 1 \\
\text { and } 2\end{array}$ & 275/1994-020 & $\begin{array}{l}\text { Grid } \\
\text { disturbance }\end{array}$ & Indirect & $\begin{array}{l}\text { Common } \\
\text { off-site } \\
\text { power lines }\end{array}$ & & $\begin{array}{l}\text { Unit } 1 \text { and Unit } 2 \text { experienced reactor trips due to a } 12 \\
\mathrm{kV} \text { auxiliary power system (reactor coolant pump (RCP) } \\
\text { feeder bus undervoltage. The event was due to a } 500 \mathrm{kV} \\
\text { system disturbance due to a transmission line fault } \\
\text { external to the PG\&E system. As a result of a transient } \\
\text { on the } 500 \mathrm{kV} \text { system, the Unit } 1 \text { and Unit } 2 \mathrm{RCP} \text { feeder } \\
\text { buses experienced undervoltage, resulting in the } \\
\text { initiation of a reactor trip signal. }\end{array}$ \\
\hline $\begin{array}{l}\text { Diablo Canyon } 1 \\
\text { and } 2\end{array}$ & 275/1996-012 & $\begin{array}{l}\text { Grid } \\
\text { disturbance }\end{array}$ & Direct & $\begin{array}{l}\text { Shared } \\
\text { system - } \\
\text { switchyard }\end{array}$ & & $\begin{array}{l}\text { On August 10, 1996, at } 1549 \text { PDT, with Units } 1 \text { and } 2 \text { in } \\
\text { Mode } 1 \text { at } 100 \text { percent power, undervoltage and } \\
\text { underfrequency conditions were experienced on both the } \\
\text { auxiliary and startup systems due to a disturbance on the } \\
500 \mathrm{kV} \text { system external to the PG\&E system. Unit } 1 \\
\text { experienced a reactor trip due to a } 12 \mathrm{kV} \text { auxiliary } \\
\text { power system RCP feeder bus undervoltage. Unit } 2 \\
\text { experienced a reactor trip due to two of four RCP } \\
\text { breakers being open. Final Safety Analysis Report } \\
\text { (FSAR) Update Section } 15.3 .4 \text {, "Complete Loss of } \\
\text { Forced Reactor Coolant Flow," states that a reactor trip } \\
\text { on RCP bus undervoltage is provided to protect against } \\
\text { conditions that can cause a loss of voltage to all RCPs, } \\
\text { i.e., loss of offsite power. In addition, a reactor trip on } \\
\text { low primary coolant loop flow is provided to protect } \\
\text { against loss of flow conditions that affect only one RCP } \\
\text { and also serves as a backup to the undervoltage trip. }\end{array}$ \\
\hline Limerick 1 and 2 & $352 / 1995-002$ & $\begin{array}{l}\text { Grid } \\
\text { disturbance }\end{array}$ & Indirect & $\begin{array}{l}\text { Common } \\
\text { off-site } \\
\text { power line }\end{array}$ & & $\begin{array}{l}\text { Unit } 1 \text { and Unit } 2 \text { Reactor Protection Systems actuated } \\
\text { as a result of main turbine trips that occurred within a } \\
\text { fraction of a second of each other. An offsite electrical } \\
\text { transmission system ground fault actuated Unit } 1 \text { and } \\
\text { Unit } 2 \text { main transformer ground overcurrent protective } \\
\text { relays tripping the generator output breakers and the } \\
\text { main turbines. The protective relays actuated as a result } \\
\text { of a breaker failure, a lightning arrestor failure, and the } \\
\text { failure of other protective relays on the transmission } \\
\text { system to properly isolate the fault from the LGS }\end{array}$ \\
\hline
\end{tabular}


Table C-1. Multi-unit Initiating Events from 1980-2014

\begin{tabular}{|c|c|c|c|c|c|c|}
\hline \multirow[t]{2}{*}{ Plant } & \multirow[t]{2}{*}{ LER No. } & \multirow[t]{2}{*}{ IE } & \multicolumn{2}{|c|}{ Type of Interaction } & \multirow[t]{2}{*}{$\begin{array}{l}\text { If external, type } \\
\text { correlation }\end{array}$} & \multirow[b]{2}{*}{$\begin{array}{l}\text { Summary of event } \\
\text { equipment. The transmission line fault that caused the } \\
\text { electrical disturbance was automatically isolated from } \\
\text { the transmission system within two (2) seconds, but not } \\
\text { before the Unit } 1 \text { and unit } 2 \text { main transformer protective } \\
\text { relays activated. An analysis of the effect of the fault } \\
\text { and associated protective relay actuations concluded that } \\
\text { the offsite transmission system stability was not } \\
\text { significantly impacted. The cause of the actuation of the } \\
\text { main transformer protection relays was the result of a } \\
\text { combination of failures. Breaker } 245 \text { at the Whitpain } \\
\text { Substation malfunctioned when opened by a } \\
\text { transmission system operator and caused a voltage spike. } \\
\text { This voltage spike caused a lightning arrestor on the } \\
\text { 220-16 transmission line to fail, resulting in a ground } \\
\text { fault. The primary and secondary ground fault detection } \\
\text { relays failed to properly trip the } 905 \text { breaker at the } \\
\text { Whitpain Substation before the LGS units tripped. }\end{array}$} \\
\hline & & & & & & \\
\hline San Onofre 2 and 3 & 361/2011-002 & $\begin{array}{l}\text { Grid } \\
\text { disturbance }\end{array}$ & Indirect & $\begin{array}{l}\text { Common } \\
\text { off-site } \\
\text { power lines }\end{array}$ & & $\begin{array}{l}\text { The loss of a } 500 \mathrm{kV} \text { line on the SDG\&E grid caused a } \\
\text { high current flow between the SDG\&E and SCE } \\
\text { transmission systems at the SONGS switchyard and the } \\
\text { automatic separation of the two systems. Both reactors } \\
\text { tripped on high pressurizer pressure followed by a } \\
\text { turbine trip. The cause of the dual unit trip was an } \\
\text { anticipated response to the external grid disturbance. }\end{array}$ \\
\hline Palo Verde 1 and 3 & 528/1991-010 & $\begin{array}{l}\text { Grid } \\
\text { disturbance }\end{array}$ & Indirect & $\begin{array}{l}\text { Common } \\
\text { off-site } \\
\text { power lines }\end{array}$ & & $\begin{array}{l}\text { Palo Verde Units } 1 \text { and } 3 \text { were operating at } \\
\text { approximately } 100 \text { percent power when a grid } \\
\text { perturbation caused the Main Turbine Control System to } \\
\text { fast close and immediately reopen the turbine control } \\
\text { valves (TCVs). The momentary reduction in steam flow } \\
\text { caused the steam bypass control valves in Units } 1 \text { and } 3 \\
\text { to quick open. Reactor trips in Units } 1 \text { and } 3 \text { occurred } \\
\text { when reactor power exceeded the Core Protection } \\
\text { Calculator Variable Overpower Trip setpoints. The } \\
\text { event was precipitated by a grid fault (i.e., a } \\
\text { simultaneous three phase fault without ground) resulting } \\
\text { from a lightning strike on the } 230 \mathrm{kV} \text { Anderson/South }\end{array}$ \\
\hline
\end{tabular}


Table C-1. Multi-unit Initiating Events from 1980-2014

\begin{tabular}{|c|c|c|c|c|c|c|}
\hline \multirow[t]{2}{*}{ Plant } & \multirow[t]{2}{*}{ LER No. } & \multirow[t]{2}{*}{ IE } & \multicolumn{2}{|c|}{ Type of Interaction } & \multirow[b]{2}{*}{\begin{tabular}{c|} 
If external, type \\
correlation
\end{tabular}} & \multirow[b]{2}{*}{$\begin{array}{l}\text { Summary of event } \\
\text { Phoenix substation feeder line. The grid voltage dropped } \\
\text { momentarily to approximately } 401 \mathrm{kV} \text { from } 525 \mathrm{kV} \text {. } \\
\text { The Power/Load Unbalance (PLUB) protection circuitry } \\
\text { as a turbine trip anticipator for turbine overspeed } \\
\text { protection. A PLUB actuation is generated by a forty } \\
\text { (40) percent decrease in generator output current within } \\
35 \text { milliseconds without a change in turbine intermediate } \\
\text { stage pressure. Normally when a PLUB actuation is } \\
\text { received, the turbine control valves (TCVs) and } \\
\text { combined intercept valves (CIVs) close. If the PLUB } \\
\text { condition clears (e.g., the load returns), the TCVs and } \\
\text { CIVs reopen. The response at both units was virtually } \\
\text { identical. The PLUB logic closed all four (4) TCVs. } \\
\text { However, because the initiating event was a grid fault } \\
\text { and not a load rejection, the generator output current } \\
\text { decrease was only momentary. The PLUB cleared (in } 22 \\
\text { cycles or 0.03 seconds) and the TCVs reopened. The } \\
\text { duration of the PLUB condition was not sufficient for } \\
\text { the relay to actuate CIV closure or to indicate the PLUB } \\
\text { annunciation on the first hit panel of the Turbine } \\
\text { Supervisory Instrumentation. }\end{array}$} \\
\hline & & & & & & \\
\hline $\begin{array}{l}\text { Beaver Valley } 1 \text { and } \\
2\end{array}$ & 334/1997-005 & $\begin{array}{l}\text { Ground fault on } \\
\text { offsite power } \\
\text { line }\end{array}$ & Indirect & $\begin{array}{l}\text { Shared } \\
\text { offsite } \\
\text { power line }\end{array}$ & & $\begin{array}{l}\text { While operating at } 100 \% \text { nominal power, Beaver Valley } \\
\text { Power Station (BVPS) Units } 1 \text { and } 2 \text { experienced } \\
\text { simultaneous reactor trips due to the opening of the } \\
\text { output breakers for both units. The event was initiated } \\
\text { by an inadvertent operation of the Bus Backup Timer } \\
\text { relay on the \#3-345 KV bus in response to a phase to } \\
\text { ground fault that occurred on the } 345 \mathrm{KV} \text { line. The } \\
\text { phase to ground fault was detected by the BVPS } \\
\text { switchyard protection equipment, which began shedding } \\
\text { various loads through the opening of line breakers. Eight } \\
\text { switchyard } 345 \mathrm{KV} \text { breakers opened; however, the } \\
\text { opening of Unit } 1 \text { and } 2 \text { output breakers PCB-331, PCB- } \\
341 \text {, PCB-352 and PCB-362 resulted in the concurrent } \\
\text { unit trips. BVPS should not have tripped any of the eight } \\
\text { (8) breakers. The } 345 \mathrm{KV} \text { bus backup protection } \\
\text { scheme, as identified on the electrical schematic }\end{array}$ \\
\hline
\end{tabular}


Table C-1. Multi-unit Initiating Events from 1980-2014

\begin{tabular}{|c|c|c|c|c|c|c|}
\hline \multirow[t]{2}{*}{ Plant } & \multirow[t]{2}{*}{ LER No. } & \multirow[t]{2}{*}{ IE } & \multicolumn{2}{|c|}{ Type of Interaction } & \multirow{2}{*}{$\begin{array}{c}\text { If external, type } \\
\text { correlation }\end{array}$} & \multirow[b]{2}{*}{$\begin{array}{l}\text { Summary of event } \\
\text { diagram, correctly identified the SBFU relay and SRU } \\
\text { wiring connections. However, this wiring was not } \\
\text { properly reflected in the associated electrical wiring } \\
\text { diagram. The as-installed wiring configuration for the } \\
\text { Unit 2, PCB-352 SBFU relay and SRU timer matched } \\
\text { the (incorrect) wiring diagram. The design review } \\
\text { process in effect at the time of installation did not detect } \\
\text { the design errors between these two diagrams. An } \\
\text { investigation identified a wiring discrepancy with the } \\
\text { current interlock of the } 43-345 \text { KV Bus Backup Timer. } \\
\text { This discrepancy involved the incorrect wiring between } \\
\text { the Unit } 2 \text { Static Breaker Failure Unit (SBFU) current } \\
\text { interlock relay for PCB-352 and its associated Static } \\
\text { Relay Unit (SRU) timer. Two outputs of the SBFU were } \\
\text { cross-connected-the relay output of this SBFU relay } \\
\text { was connected to the current input of the SRU timer and } \\
\text { the current output of the SBFU relay was connected to } \\
\text { the relay input of the SRU timer. }\end{array}$} \\
\hline & & & & & & \\
\hline $\begin{array}{l}\text { Comanche Peak } 1 \\
\text { and } 2\end{array}$ & 445/2003-003 & $\begin{array}{l}\text { Ground fault on } \\
\text { offsite power } \\
\text { line }\end{array}$ & Direct & $\begin{array}{l}\text { Shared } \\
\text { system - } \\
\text { switchyard }\end{array}$ & & $\begin{array}{l}\text { A phase to ground fault occurred on the Parker line } ~ \\
\text { miles from the CPSES } 345 \mathrm{kV} \text { switchyard. The failure of } \\
\text { the switchyard breaker protection to adequately } \\
\text { recognize and clear the fault resulted in a total loss of } \\
\text { the } 345 \mathrm{kV} \text { switchyard. The fault detector relays in both } \\
\text { the primary and backup protection schemes of the } \\
\text { CPSES Parker line circuit breaker did not function } \\
\text { properly. Because of the failure of the primary and } \\
\text { backup protection schemes for the CPSES to Parker } \\
\text { transmission line breaker, the fault resulted in a total loss } \\
\text { of the CPSES } 345 \mathrm{kV} \text { switchyard } ~ 20 \text { seconds after the } \\
\text { fault began. The trip of Units } 1 \text { and } 2 \text { as a result of a } \\
\text { disturbance on one of the } 345 \mathrm{kV} \text { transmission lines was } \\
\text { not expected. TXU Energy believes that the primary and } \\
\text { backup fault detection circuit relays did not function as } \\
\text { designed. A loss of non-emergency AC power to the } \\
\text { station auxiliaries is classified as an ANS Condition II } \\
\text { transient - a fault of moderate frequency. }\end{array}$ \\
\hline
\end{tabular}


Table C-1. Multi-unit Initiating Events from 1980-2014

\begin{tabular}{|c|c|c|c|c|c|c|}
\hline Plant & LER No. & IE & Type o & Interaction & $\begin{array}{l}\text { If external, type } \\
\text { correlation }\end{array}$ & Summary of event \\
\hline Palo Verde 1 and 3 & 528/1996-004 & $\begin{array}{l}\text { Ground fault on } \\
\text { offsite power } \\
\text { line }\end{array}$ & Direct & \begin{tabular}{|l|} 
Shared \\
offsite \\
power line
\end{tabular} & & $\begin{array}{l}\text { The grid disturbance originated in the Pacific Northwest } \\
\text { when power lines sagged into trees due to high load } \\
\text { conditions and high temperatures and "flashed-over" or } \\
\text { short-circuited. The grid disturbance resulted in a } \\
\text { Western power outage. Palo Verde Units } 1,2 \text {, and } 3 \\
\text { experienced numerous electrical alarms. The grid } \\
\text { perturbation was characterized by an initial site load } \\
\text { decrease of approximately } 700 \text { megawatts followed by a } \\
\text { sizable load demand increase. The load decrease was } \\
\text { accompanied by a main turbine first stage pressure } \\
\text { decrease (turbine control valves throttled closed). The } \\
\text { steam bypass control system (SBCS) responded as } \\
\text { designed by quick opening the X group SBCVs. The } \\
\text { remaining SBCVs responded by modulating to control } \\
\text { pressure as expected. The opening of the multiple } \\
\text { SBCVs and the sudden increased load demand resulted } \\
\text { in an excess steam demand scenario which reduced the } \\
\text { reactor coolant system (RCS) cold leg temperature } \\
\text { which in turn inserted positive reactivity [due to the } \\
\text { negative moderator temperature coefficient (MTC) in } \\
\text { the units]. With the sudden load demand increase, the } \\
\text { SBCVs began to close. At this time, the Unit } 1 \text { and Unit } \\
3 \text { reactors tripped on low departure from nucleate } \\
\text { boiling ratio (DNBR), as expected, when the core } \\
\text { protection calculators (CPCs) generated auxiliary trips } \\
\text { on the rate of change of power (i.e., variable over power } \\
\text { trip (VOPT)). }\end{array}$ \\
\hline $\begin{array}{l}\text { Browns Ferry 1,2, } \\
\text { and } 3\end{array}$ & 259/2011-001 & $\begin{array}{l}\text { High wind } \\
\text { induced LOOP }\end{array}$ & Indirect & $\begin{array}{l}\text { Common } \\
\text { location }\end{array}$ & $\begin{array}{l}\text { Source correlated } \\
\text { hazards }\end{array}$ & $\begin{array}{l}\text { Severe weather caused grid instability and loss of all } \\
500 \mathrm{kV} \text { offsite power sources that resulted in automatic } \\
\text { scrams of all three units. following offsite power grid } \\
\text { oscillations (due to severe weather including high winds } \\
\text { and tornadoes) and subsequent Unit } 1 \text { and } 2 \text { power } \\
\text { reductions from } 100 \text { percent to } 75 \text { percent to attempt to } \\
\text { correct the condition, BFN experienced a complete loss } \\
\text { of the } 500-\mathrm{kV} \text { offsite power system. This resulted in } \\
\text { automatic scrams of Units } 1,2 \text {, and } 3 \text {. After the event, } \\
\text { only one } 161-\mathrm{kV} \text { line remained available for offsite }\end{array}$ \\
\hline
\end{tabular}


Table C-1. Multi-unit Initiating Events from 1980-2014

\begin{tabular}{|c|c|c|c|c|c|c|}
\hline Plant & LER No. & IE & \multicolumn{2}{|c|}{ Type of Interaction } & $\begin{array}{c}\text { If external, type } \\
\text { correlation }\end{array}$ & $\begin{array}{l}\text { Summary of event } \\
\text { power - all (seven) 500-kV lines and one (of two) 161- } \\
\text { kV line were lost. }\end{array}$ \\
\hline $\begin{array}{l}\text { Calvert Cliffs } 1 \text { and } \\
2\end{array}$ & 317/1993-003 & $\begin{array}{l}\text { Incorrect } \\
\text { operator } \\
\text { response based } \\
\text { on transient at } \\
\text { other unit }\end{array}$ & Direct & $\begin{array}{l}\text { Shared } \\
\text { control room }\end{array}$ & & $\begin{array}{l}\text { A flashover relay in the Calvert Cliffs switchyard } \\
\text { actuated, causing the loss of the } 500 \text { kv "Red" bus } \\
\text { feeding Unit } 2 \text {. Unit } 2 \text { immediately tripped on low } \\
\text { coolant flow. Unit } 1 \text { was manually tripped } 25 \text { seconds } \\
\text { later by operators anticipating a total loss of offsite } \\
\text { power. The flashover protection for breaker } 552-61 \text { was } \\
\text { enabled when it was not needed to protect an electrically } \\
\text { isolated breaker. Only breakers } 552-62 \text { and } 63 \text { actually } \\
\text { needed to be tagged out for the work being performed. } \\
\text { The decision to open breaker } 552-61 \text { was made after the } \\
\text { crews reported to the switchyard. The decision to trip } \\
\text { Unit } 1 \text { resulted from the CRSs having quickly analyzed } \\
\text { various inputs and concluded that a loss of offsite power } \\
\text { was underway, His decision was conservative. However, } \\
\text { manual trip of the unit was not optimal because Unit } 1 \\
\text { would not have tripped on loss of the Red Bus. The } \\
\text { control room supervisor (CRS) believed, based on the } \\
\text { loss of Control Room lighting and trip of Unit } 2 \text {, that the } \\
\text { plant was in the process of losing power to both units. } \\
\text { He did not fully recognize and synthesize all available } \\
\text { information. This was due in part to distractions caused } \\
\text { by the automatic shutdown of Unit } 2 \text {. }\end{array}$ \\
\hline Vogtle 1 and 2 & 424/1995-002 & Lightning & Indirect & Proximity & & $\begin{array}{l}\text { During a severe thunderstorm, multiple lightning strikes } \\
\text { occurred in the immediate vicinity of the plant site with } \\
\text { at least one direct lightning strike on the plant. Twenty- } \\
\text { one of fifty-three reactor control rods on Unit } 1 \text { and all } \\
\text { control rods on Unit } 2 \text { dropped into the cores. } \\
\text { Approximately } 1.5 \text { seconds later, both reactors received } \\
\text { a trip signal for low pressurizer pressure. The cause of } \\
\text { this event was voltage surges in the rod control systems } \\
\text { of both units. Voltage surges, initiated by the lightning } \\
\text { strikes, affected low voltage circuitry in both rod control } \\
\text { systems, causing some of the control rod drive } \\
\text { mechanisms (CRDMs) on Unit } 1 \text { and all CRDMs on }\end{array}$ \\
\hline
\end{tabular}


Table C-1. Multi-unit Initiating Events from 1980-2014

\begin{tabular}{|c|c|c|c|c|c|c|}
\hline \multirow[t]{2}{*}{ Plant } & \multirow[t]{2}{*}{ LER No. } & \multirow[t]{2}{*}{ IE } & \multicolumn{2}{|c|}{ Type of Interaction } & \multirow[t]{2}{*}{$\begin{array}{c}\text { If external, type } \\
\text { correlation }\end{array}$} & \multirow{2}{*}{$\begin{array}{l}\text { Summary of event } \\
\text { Unit } 2 \text { to lose power to stationary gripper coils. This } \\
\text { allowed the control rods to drop into the core and both } \\
\text { reactors immediately went subcritical. }\end{array}$} \\
\hline & & & & & & \\
\hline $\begin{array}{l}\text { Comanche Peak } 1 \\
\text { and } 2\end{array}$ & 445/1995-002 & Lightning & Indirect & Proximity & & $\begin{array}{l}\text { A reactor trip of both CPSES Units } 1 \text { and } 2 \text { occurred } \\
\text { from a lightning strike to the plant. The lightning strike } \\
\text { created a voltage surge on the Rod Control System } \\
\text { Neutral bus in both units causing a partial rod drop. The } \\
\text { reactor trips actuated on the resulting Power Range } \\
\text { Negative Rate Reactor Trip. The plant equipment } \\
\text { response to the reactor trips was consistent with that } \\
\text { expected for the existing plant conditions. The cause of } \\
\text { this event was determined to be: the failure of the } \\
\text { lightning protection system to provide effective } \\
\text { protection against lightning induced perturbations on } \\
\text { sensitive plant electrical equipment. The cause of a } \\
\text { reactor trip from a lightning strike as a failure of the } \\
\text { plant ground system to dissipate the current transient } \\
\text { from the lightning strike and creating a surge on the } 120 \\
\text { VAC supplies to the rod control power supplies. The } \\
\text { corrective actions installed surge suppression on the } 120 \\
\text { VAC lines. }\end{array}$ \\
\hline Braidwood 1 and 2 & 456/1989-006 & Lightning & Indirect & $\begin{array}{l}\text { Common } \\
\text { off-site } \\
\text { power lines }\end{array}$ & & $\begin{array}{l}\text { The Station experienced Lightning induced voltage } \\
\text { transients causing multiple rod drive overvoltage } \\
\text { protection devices to actuate on Unit } 1 \text { and } 2 \text {, } \\
\text { respectively. On Unit } 1 \text { ten out of ten overvoltage } \\
\text { protectors actuated. On Unit } 2 \text { seven out of ten } \\
\text { overvoltage protectors actuated. This removed power to } \\
\text { various rod drive control cards and allowed numerous } \\
\text { control rods to drop. Both reactors tripped due to } \\
\text { Negative Rate Trip on the power range. The root cause } \\
\text { is inadequate protection and isolation of the Rod Control } \\
\text { System from Lightning induced transients. }\end{array}$ \\
\hline $\begin{array}{l}\text { Peach Bottom } 2 \text { and } \\
3\end{array}$ & 227/2003-004 & LOOP & Direct & $\begin{array}{l}\text { Shared } \\
\text { system - } \\
\text { emergency } \\
\text { buses }\end{array}$ & & $\begin{array}{l}\text { Units } 2 \text { and } 3 \text { automatically scrammed after a } \\
\text { temporary loss of two of the three off-site power } \\
\text { sources, caused by an electrical grid disturbance. The } \\
\text { disturbance was the result of the failure of off-site grid }\end{array}$ \\
\hline
\end{tabular}


Table C-1. Multi-unit Initiating Events from 1980-2014

\begin{tabular}{|c|c|c|c|c|c|c|}
\hline \multirow[t]{2}{*}{ Plant } & \multirow[t]{2}{*}{ LER No. } & \multirow[t]{2}{*}{ IE } & \multicolumn{2}{|c|}{ Type of Interaction } & \multirow[b]{2}{*}{$\begin{array}{c}\text { If external, type } \\
\text { correlation }\end{array} \mid$} & \multirow[b]{2}{*}{$\begin{array}{l}\text { Summary of event } \\
\text { protective relaying during a lightning storm } \\
\text { approximately } 35 \text { miles away from the site and caused a } \\
\text { 16-second loss of two off-site sources. The two sources } \\
\text { that lost power were lined up to the two plant emergency } \\
\text { transformers, which feed the eight plant emergency } \\
\text { busses. This condition resulted in de-energization of the } \\
\text { emergency busses. Normal off-site power supplied by } \\
\text { the third off-site source was not affected and continued } \\
\text { to provide power to two of the four plant non-emergency } \\
13 \mathrm{kV} \text { busses. }\end{array}$} \\
\hline & & & & & & \\
\hline $\begin{array}{l}\text { Calvert Cliffs } 1 \text { and } \\
2\end{array}$ & $317 / 1987-012$ & LOOP & Indirect & $\begin{array}{l}\text { Common } \\
\text { off-site } \\
\text { power lines }\end{array}$ & & $\begin{array}{l}\text { a fault developed on one (Transmission Line 5052) of } \\
\text { the two 500KV transmission lines connecting Calvert } \\
\text { Cliffs Nuclear Power Plant to the company's bulk power } \\
\text { distribution grid at Waugh Chapel Station. The circuit } \\
\text { breakers for line } 5052 \text { at Waugh Chapel and Calvert } \\
\text { Cliffs tripped to isolate the fault. In addition, circuit } \\
\text { breakers at Calvert Cliffs for the other transmission line } \\
\text { (line 5051) incorrectly tripped open. This resulted in } \\
\text { isolating the generating plant from the power grid } \\
\text { resulting in both reactors tripping on loss of load of all } \\
\text { off site nonemergency AC power. The fault on } \\
\text { transmission line } 5052 \text { was caused by a tree that came in } \\
\text { contact with the transmission line. The cause of } \\
\text { transmission line } 5051 \text { circuit breakers tripping } \\
\text { incorrectly was determined to be the fault of a defective } \\
\text { logic circuit card in the primary static relay panel. This } \\
\text { circuit card allowed the relays to trip the circuit breaker } \\
\text { despite the absence of a "Permissive Signal" from the } \\
\text { corresponding relays at Waugh Chapel. The opening of } \\
\text { circuit breakers on both } 500 \mathrm{KV} \text { transmission lines } \\
\text { isolated Calvert Cliffs from the rest of the company's } \\
\text { power grid. This resulted in both Unit One and Unit } \\
\text { Two reactors tripping on a loss of load followed } \\
\text { immediately by a loss of all nonemergency AC power. }\end{array}$ \\
\hline $\begin{array}{l}\text { Beaver Valley } 1 \text { and } \\
2\end{array}$ & 334/1993-013 & LOOP & Direct & $\begin{array}{l}\text { Shared } \\
\text { system - }\end{array}$ & & $\begin{array}{l}\text { Unit } 1 \text { was operating at } 100 \text { percent power and Unit } 2 \\
\text { was in a refueling outage. Unit } 1 \text { experienced a large }\end{array}$ \\
\hline
\end{tabular}


Table C-1. Multi-unit Initiating Events from 1980-2014

\begin{tabular}{|c|c|c|c|c|c|c|}
\hline \multirow[t]{2}{*}{ Plant } & \multirow[t]{2}{*}{ LER No. } & \multirow[t]{2}{*}{ IE } & \multicolumn{2}{|c|}{ Type of Interaction } & \multirow[t]{2}{*}{$\begin{array}{c}\text { If external, type } \\
\text { correlation }\end{array}$} & \multirow[b]{2}{*}{$\begin{array}{l}\text { Summary of event } \\
\text { loss of offsite load when ten offsite feed breakers in the } \\
\text { Beaver Valley switchyard opened as a result of an } \\
\text { inadvertent underfrequency system separation actuation. } \\
\text { The load reduction caused the Unit } 1 \text { turbine to trip and } \\
\text { reactor scram. The opening of the switchyard feed } \\
\text { breakers and the resultant Unit } 1 \text { generator trip resulted } \\
\text { in a loss of offsite power to Units } 1 \text { and } 2 \text {. The cause of } \\
\text { the LOOP was personnel error. While performing } \\
\text { maintenance, the maintenance crew started checking } \\
\text { auxiliary contacts for possible misalignment problems. } \\
\text { During this verification, underfrequency tripping relays } \\
\text { were actuated when } 125 \text { Volt DC from one set of } \\
\text { contacts was inadvertently connected to another set of } \\
\text { contacts. This resulted in the opening of seven } 345 \mathrm{KV} \\
\text { feed breakers and three } 138 \mathrm{KV} \text { feed breakers. }\end{array}$} \\
\hline & & & & switchyard & & \\
\hline North Anna 1 and 2 & $338 / 2011-003$ & LOOP & Indirect & $\begin{array}{l}\text { Common } \\
\text { location }\end{array}$ & $\begin{array}{l}\text { Induced hazard } \\
\text { (seismically- } \\
\text { induced LOOP) }\end{array}$ & $\begin{array}{l}\text { A magnitude } 5.8 \text { earthquake was felt and recognized as } \\
\text { an earthquake by the Main Control Room (MCR) } \\
\text { operators. (No alarms were received on the Seismic } \\
\text { Monitoring Instrumentation Panel in the MCR because } \\
\text { of the momentary loss of semi-vital power to the Panel } \\
\text { as a result of the loss of offsite power and emergency } \\
\text { diesel generator (EDG) start and load timing.) The } \\
\text { earthquake caused multiple transformers to lock out due } \\
\text { to activation of the sudden pressure relays resulting in } \\
\text { the loss of offsite power. It was subsequently determined } \\
\text { that the sudden pressure relays operated as designed as a } \\
\text { result of the earthquake induced pressure pulse; no } \\
\text { electrical fault occurred. The earthquake also caused a } \\
\text { series of reactor trip signals to both Unit } 1 \text { and Unit } 2 \\
\text { reactors. }\end{array}$ \\
\hline LaSalle 1 and 2 & $373 / 2013-002$ & LOOP & Direct & \begin{tabular}{|l} 
Shared \\
system - \\
switchyard
\end{tabular} & & $\begin{array}{l}\text { An initial lightning struck on a } 138 \mathrm{KV} \text { line resulted in a } \\
\text { phase-to-ground fault that was subsequently cleared. } \\
\text { Minutes later, a second phase-to-ground fault on that } \\
\text { same line occurred and all } 345 \mathrm{KV} \text { oil circuit breakers } \\
\text { (OCBs) in the main switchyard opened, resulting in a } \\
\text { loss of offsite power and reactor scrams on both Units. }\end{array}$ \\
\hline
\end{tabular}


Table C-1. Multi-unit Initiating Events from 1980-2014

\begin{tabular}{|c|c|c|c|c|c|c|}
\hline \multirow[t]{2}{*}{ Plant } & \multirow[t]{2}{*}{ LER No. } & \multirow[t]{2}{*}{ IE } & \multicolumn{2}{|c|}{ Type of Interaction } & \multirow[t]{2}{*}{$\begin{array}{c}\text { If external, type } \\
\text { correlation }\end{array}$} & \multirow[b]{2}{*}{$\begin{array}{l}\text { Summary of event } \\
\text { The initiating event was a lightning strike on 138KV } \\
\text { Line in the main switchyard. The } 138 \mathrm{kV} \text { line sustained } \\
\text { heavy damage to phase "C" insulators. The root cause of } \\
\text { the event was determined to be degradation of the } \\
138 \mathrm{kV} \text { switchyard grounding system that allowed a } \\
\text { lightning induced fault to flash over onto the DC } \\
\text { protective system. The grounding system degradation } \\
\text { was due to poor workmanship during original } \\
\text { construction. This degradation allowed a fault initiated } \\
\text { by a lightning strike in the } 138 \mathrm{kV} \text { switchyard to damage } \\
\text { the shared DC protection system. Another contributor to } \\
\text { the event was determined to be inadequate lightning } \\
\text { shielding of the } 138 \mathrm{kV} \text { switchyard. }\end{array}$} \\
\hline & & & & & & \\
\hline Catawba 1 and 2 & 413/2006-001 & LOOP & Indirect & $\begin{array}{l}\text { CCF - relay } \\
\text { tap setting } \\
\text { changes not } \\
\text { made } \\
\text { Shared } \\
\text { system - } \\
\text { switchyard }\end{array}$ & & $\begin{array}{l}\text { Both Catawba units tripped automatically following a } \\
\text { loss of offsite power (LOOP) event. The event began } \\
\text { when a fault occurred internal to a current transformer } \\
\text { associated with one of the switchyard power circuit } \\
\text { breakers. A second current transformer failure, along } \\
\text { with the actuation of differential relaying associated } \\
\text { with both switchyard busses, cleared both busses and } \\
\text { separated the units from the grid. The root cause analysis } \\
\text { for this event determined that in 1981, certain } \\
\text { switchyard relay tap setting changes for the yellow and } \\
\text { red switchyard bus differential protective relays were } \\
\text { not implemented at Catawba. Power Delivery } \\
\text { documentation was subsequently erroneously updated to } \\
\text { indicate that the changes had been made. Thus, The loss } \\
\text { of offsite power during this event resulted from the } \\
\text { inadequately set relays. }\end{array}$ \\
\hline $\begin{array}{l}\text { Palo Verde } 1,2 \text {, and } \\
3\end{array}$ & 528/2004-006 & LOOP & Direct & $\begin{array}{l}\text { Shared } \\
\text { system - } \\
\text { switchyard }\end{array}$ & & $\begin{array}{l}\text { A } 230 \mathrm{kV} \text { line shorted to ground when a ceramic } \\
\text { insulator on the line failed. Because of a defective relay, } \\
\text { the fault was not cleared for approximately } 38 \text { seconds. } \\
\text { The fault cascaded into the protective tripping of a } \\
\text { number of } 230 \mathrm{kV} \text { and } 525 \mathrm{kV} \text { transmission lines, which } \\
\text { ultimately led to the Loss of Offsite Power (LOOP) at } \\
\text { the Palo Verde switchyard. Subsequently, all three Palo }\end{array}$ \\
\hline
\end{tabular}


Table C-1. Multi-unit Initiating Events from 1980-2014

\begin{tabular}{|c|c|c|c|c|c|c|}
\hline \multirow[t]{2}{*}{ Plant } & \multirow[t]{2}{*}{ LER No. } & \multirow[t]{2}{*}{ IE } & \multicolumn{2}{|c|}{ Type of Interaction } & \multirow[t]{2}{*}{$\begin{array}{c}\text { If external, type } \\
\text { correlation }\end{array}$} & \multirow{2}{*}{$\begin{array}{l}\text { Summary of event } \\
\text { Verde Units were disconnected from the Palo Verde } \\
\text { Switchyard by generator protection. A loss of offsite } \\
\text { power (LOOP) condition existed when all transmission } \\
\text { lines to the switchyard opened. All three Palo Verde } \\
\text { Units' turbines tripped on over speed and subsequently } \\
\text { all reactors tripped. }\end{array}$} \\
\hline & & & & & & \\
\hline $\begin{array}{l}\text { Calvert Cliffs } 1 \text { and } \\
2\end{array}$ & $\begin{array}{l}317 / 2014-001 \\
\text { EN 49754, June } \\
22,2014\end{array}$ & Loss of ac bus & Direct & $\begin{array}{l}\text { Shared } \\
\text { system- } \\
\text { switchyard }\end{array}$ & & $\begin{array}{l}\text { From NRC Event Number (EN) 49754: Dual Unit Trip } \\
\text { due to loss of a } 13 \mathrm{KV} \text { bus. All safety functions are met } \\
\text { for both units. Unit } 1 \text { remained with normal heat } \\
\text { removal. Unit } 2 \text { lost power to its normal heat sink and is } \\
\text { stable on Auxiliary Feed water and Atmospheric Dump } \\
\text { Valves for temperature control. Both trips were } \\
\text { automatic trips. Due to loss of power an Under Voltage } \\
\text { actuation occurred on both units ('14' and '24' } 4 \text { Kv bus). } \\
\text { Due to loss of main feed on Unit 2, an Auxiliary } \\
\text { Feedwater Actuation System actuation occurred on Unit } \\
\text { 2. The cause of the event is under further investigation. }\end{array}$ \\
\hline Cook 1 and 2 & $315 / 2003-003$ & Loss of ESW & Direct & $\begin{array}{l}\text { Shared } \\
\text { system - } \\
\text { intake bay }\end{array}$ & & $\begin{array}{l}\text { A large school of alewives began impinging on the } \\
\text { traveling water screens (TWS) located upstream of the } \\
\text { common forebay of the circulating water (CW) and the } \\
\text { essential service water (ESW) systems. As the volume } \\
\text { of fish impinging on the TWS increased, the TWS } \\
\text { system was overwhelmed. Differential pressure across } \\
\text { the screens increased rapidly, resulting in most of the } \\
\text { screens stopping due to either shear pin failure or } \\
\text { tripping of breaker thermal overloads, and the eventual } \\
\text { failure of multiple screen panels within the TWS system. } \\
\text { As a result of the screen panel failures, the fish } \\
\text { subsequently entered the suction of the CW and ESW } \\
\text { pumps. Components serviced by the CW and ESW } \\
\text { pumps began fouling. Unit } 1 \text { was manually tripped due } \\
\text { to fouling of the main feed pump condensers and Unit } 2 \\
\text { was manually tripped due to degraded forebay } \\
\text { conditions. }\end{array}$ \\
\hline LaSalle 1 and 2 & 373/1996-008 & Loss of ESW & Direct & $\begin{array}{l}\text { Shared } \\
\text { system - }\end{array}$ & & $\begin{array}{l}\text { To stop ground water inleakage and prepare the building } \\
\text { for painting, workers began sealing cracks in the walls }\end{array}$ \\
\hline
\end{tabular}


Table C-1. Multi-unit Initiating Events from 1980-2014

\begin{tabular}{|c|c|c|c|c|c|c|}
\hline \multirow[t]{2}{*}{ Plant } & \multirow[t]{2}{*}{ LER No. } & \multirow[t]{2}{*}{ IE } & \multicolumn{2}{|c|}{ Type of Interaction } & \multirow[b]{2}{*}{\begin{tabular}{c|l}
$\begin{array}{c}\text { If external, type } \\
\text { correlation }\end{array}$ & \\
& $\mathrm{a}$ \\
il \\
$\mathrm{s}$ \\
$\mathrm{y}$ \\
$\mathrm{f}$ \\
$\mathrm{E}$ \\
$\mathrm{V}$ \\
$\mathrm{r}$ \\
$\mathrm{y}$ \\
$\mathrm{H}$ \\
$\mathrm{v}$ \\
$\mathrm{i}$ \\
$\mathrm{p}$ \\
$\mathrm{n}$ \\
$\mathrm{o}$ \\
$\mathrm{d}$ \\
$\mathrm{tl}$ \\
$\mathrm{f}$ \\
$\mathrm{o}$ \\
$\mathrm{o}$ \\
$\mathrm{b}$ \\
$\mathrm{i}$ \\
$\mathrm{a}$ \\
$\mathrm{c}$ \\
$\mathrm{c}$ \\
$\mathrm{T}$ \\
$\mathrm{c}$ \\
$\mathrm{S}$ \\
\end{tabular}} & \multirow[b]{2}{*}{$\begin{array}{l}\text { Summary of event } \\
\text { and floors of the Lake Screen House (LSH) with an } \\
\text { injectable sealant. While doing floor repairs, the workers } \\
\text { started fixing cracks on the top or ceiling of a service } \\
\text { water tunnel which runs the length of the building 20 } \\
\text { feet below lake level. The tunnel is the source for the } \\
\text { Essential Service Water System, Non-essential Service } \\
\text { Water Systems and the Fire Protection systems. As they } \\
\text { repaired these cracks, the workers believed that they } \\
\text { were working on a concrete floor laid over soil. } \\
\text { However, instead of the sealant being injected into a } \\
\text { void under the building floor, the material was injected } \\
\text { into the tunnel. On June 19, } 1996 \text { with both units at full } \\
\text { power, high differential pressure occurred on the on-line } \\
\text { non-essential service water strainers. Operators also } \\
\text { observed that service water header pressure had } \\
\text { decreased below normal. Upon inspection, two of the } \\
\text { three strainers were found in automatic backwash but } \\
\text { failures on the backwash valve actuators and/or binding } \\
\text { of the strainer basket diverters prevented proper flushing } \\
\text { of accumulated material. Power reductions were done on } \\
\text { both units to reduce the service water heat loads and } \\
\text { isolate each strainer, one at a time, to repair the valve } \\
\text { actuators and free the diverter. The station declared all } \\
\text { Core Standby Cooling Systems (CSCS), Emergency } \\
\text { Core Cooling Systems (ECCSs), and DGs inoperable. } \\
\text { The foreign material had the potential to cause a } \\
\text { common mode failure of the Essential Service Water } \\
\text { System. }\end{array}$} \\
\hline & & & & ESW & & \\
\hline Braidwood 1 and 2 & $456 / 1988-025$ & \begin{tabular}{|l|} 
Loss of \\
instrument air
\end{tabular} & Direct & $\begin{array}{l}\text { Shared } \\
\text { system - } \\
\text { instrument } \\
\text { air }\end{array}$ & & $\begin{array}{l}\text { A rapid decrease in the instrument air header pressure } \\
\text { caused the feedwater regulating valves to go closed. } \\
\text { This decreased flow to the steam generators on both } \\
\text { units and both Units were manually tripped because of } \\
\text { decreasing steam generator water levels. The cause of } \\
\text { this event was inadequate installation of a coupling in } \\
\text { the instrument air header during construction. }\end{array}$ \\
\hline McGuire 1 and 2 & 369/1997-009 & Loss of non- & Direct & Shared & & The trip of an auxiliary supply breaker, while the Units \\
\hline
\end{tabular}


Table C-1. Multi-unit Initiating Events from 1980-2014

\begin{tabular}{|c|c|c|c|c|c|c|}
\hline \multirow[t]{2}{*}{ Plant } & \multirow[t]{2}{*}{ LER No. } & \multirow{2}{*}{$\frac{\text { IE }}{\text { vital ac power }}$} & \multicolumn{2}{|c|}{ Type of Interaction } & \multirow[b]{2}{*}{\begin{tabular}{c|l} 
If external, type & \\
correlation & \\
& v \\
v \\
u \\
1 \\
c \\
C \\
D \\
tl \\
t \\
n \\
is \\
f \\
L \\
it \\
a \\
s \\
tl \\
2 \\
B \\
e \\
p \\
v \\
L \\
c \\
c
\end{tabular}} & \multirow[b]{2}{*}{$\begin{array}{l}\text { Summary of event } \\
\text { were in an abnormal alignment, caused the loss of non- } \\
\text { vital power to plant components on both Units, which } \\
\text { ultimately resulted in a reactor trip at both units. The } \\
125 \text { VDC Auxiliary Control Power System (EPK) } \\
\text { consists of batteries CXA and CXB, battery chargers } \\
\text { CXA, CXB, and CXS, distribution centers DCA and } \\
\text { DCB, and molded-case circuit breakers. The design of } \\
\text { the system provides for the manual cross connection of } \\
\text { two distribution centers during periods of battery } \\
\text { maintenance. EPK System Battery CXA had been } \\
\text { isolated from the DCA Bus for equalize charge } \\
\text { following annual service testing and maintenance. Bus } \\
\text { DCA had been cross tied to Bus DCB and, as a result, } \\
\text { inverters 1KU and KXA were shut down with the } \\
\text { associated Power Panel Boards (1KU and KXA) being } \\
\text { supplied power from the regulated alternate AC source } \\
\text { through Regulated Power Distribution Center MKA. At } \\
\text { 2146:31.33, Breaker MKA-1B, Inverter KXA Manual } \\
\text { Bypass Switch Alternate Supply, tripped. This de- } \\
\text { energized Power Panel Board KXA. Loss of alternate } \\
\text { power to Power Panel Board KXA caused loss of non- } \\
\text { vital power to a number of plant components on both } \\
\text { Units, which, in turn, caused loss of non-safety related } \\
\text { control and indication functions associated with those } \\
\text { components. }\end{array}$} \\
\hline & & & & $\begin{array}{l}\text { system - } \\
\text { non-vital } \\
125 \text { VAC }\end{array}$ & & \\
\hline McGuire 1 and 2 & 369/2011-002 & $\begin{array}{l}\text { Loss of service } \\
\text { water }\end{array}$ & Direct & $\begin{array}{l}\text { Shared } \\
\text { system - } \\
\text { nuclear } \\
\text { service } \\
\text { water system }\end{array}$ & & $\begin{array}{l}\text { Unit } 1 \text { and Unit } 2 \text { Nuclear Service Water System (RN) } \\
\text { "A" and "B" Trains had been declared inoperable due to } \\
\text { RN strainer macro-fouling. LCO } 3.0 .3 \text { required that Unit } \\
1 \text { and Unit } 2 \text { be placed in MODE } 3 \text { within } 7 \text { hours, } \\
\text { MODE } 4 \text { within } 13 \text { hours and MODE } 5 \text { within } 37 \text { hours. } \\
\text { The manual trip of placed Unit } 1 \text { in MODE } 3 \text {; Unit } 2 \\
\text { was manually shutdown to MODE } 3 \text {. }\end{array}$ \\
\hline $\begin{array}{l}\text { Beaver Valley } 1 \text { and } \\
2\end{array}$ & $334 / 2002-001$ & $\begin{array}{l}\text { Low River } \\
\text { Water level }\end{array}$ & Direct & $\begin{array}{l}\text { Shared } \\
\text { system - } \\
\text { Ultimate }\end{array}$ & & $\begin{array}{l}\text { Measured silt levels in three bays of the BVPS Main } \\
\text { Intake Structure had exceeded acceptable limits to } \\
\text { assure adequate inflow from the Ohio River into the }\end{array}$ \\
\hline
\end{tabular}


Table C-1. Multi-unit Initiating Events from 1980-2014

\begin{tabular}{|c|c|c|c|c|c|c|}
\hline \multirow[t]{2}{*}{ Plant } & \multirow[t]{2}{*}{ LER No. } & \multirow{2}{*}{$\begin{array}{c}\text { IE } \\
\text { Loss of ultimate } \\
\text { heat sink (UHS) }\end{array}$} & \multicolumn{2}{|c|}{ Type of Interaction } & \multirow[b]{2}{*}{\begin{tabular}{c|l}
$\begin{array}{c}\text { If external, type } \\
\text { correlation }\end{array}$ & \\
& $\mathrm{I}$ \\
$\mathrm{L}$ \\
$\mathrm{d}$ \\
$\mathrm{e}$ \\
$\mathrm{c}$ \\
$\mathrm{t}$ \\
$\mathrm{K}$ \\
$\mathrm{b}$ \\
$\mathrm{r}$ \\
$\mathrm{r}$ \\
$\mathrm{L}$ \\
$\mathrm{b}$ \\
$\mathrm{b}$ \\
$\mathrm{H}$ \\
$\mathrm{s}$ \\
$\mathrm{r}$ \\
$\mathrm{b}$ \\
$\mathrm{c}$ \\
$\mathrm{c}$ \\
$\mathrm{p}$
\end{tabular}} & \multirow[b]{2}{*}{$\begin{array}{l}\text { Summary of event } \\
\text { Intake Structure bays in order to provide sufficient } \\
\text { ultimate heat sink cooling needs during the design basis } \\
\text { / licensing basis bounding extreme low river water } \\
\text { event. This was identified during follow-up evaluations } \\
\text { of issues raised during a Latent Issues design review of } \\
\text { the BVPS Service Water System. Even though the Ohio } \\
\text { River has never approached the design basis / licensing } \\
\text { basis extreme low water level, the BVPS Unit } 1 \text { safety } \\
\text { related River Water System and the BVPS Unit } 2 \text { safety } \\
\text { related Service Water System must have adequate } \\
\text { ultimate heat sink capability to adequately support the } \\
\text { bounding low probability low river water level design } \\
\text { basis / licensing basis postulated scenario. Current } \\
\text { BVPS design analyses show that adequate inflow to the } \\
\text { suction of the River/Service Water System pumps may } \\
\text { not be assured with greater than } 22 \text { inches of solid } \\
\text { blockage in an Intake Structure bay. The accumulation } \\
\text { of silt in the Intake Structure is only a potential concern } \\
\text { during an extreme low river water level condition. The } \\
\text { probability of an extreme low river water level is small. }\end{array}$} \\
\hline & & & & Heat Sink & & \\
\hline ANO 1 and 2 & 313/2013-001 & $\begin{array}{l}\text { Man-made } \\
\text { event - drop of } \\
529 \text { ton stator }\end{array}$ & Indirect & Proximity & & $\begin{array}{l}\text { During lifting and removal of the original ANO-1 Stator } \\
\text { (weighing } ~ 529 \text { tons), the temporary lift assembly } \\
\text { collapsed, resulting in the Stator falling onto the turbine } \\
\text { deck floor, then rolling down into the ANO-1 train bay } \\
\text { adjacent to ANO-2. Structural members of the Stator } \\
\text { temporary lift assembly fell onto the ANO-1 and ANO-2 } \\
\text { turbine deck floor. As debris fell into the train bay, an } 8 \\
\text { inch firewater pipe was ruptured and the Alternate AC } \\
\text { Diesel Generator (AACDG) electrical tie to ANO-1 was } \\
\text { severed, rendering the AACDG unavailable to either } \\
\text { ANO-1 or ANO-2. When the Stator impacted the ANO- } \\
1 \text { turbine deck floor, part of the concrete and steel floor } \\
\text { structure collapsed onto electrical buses beneath the } \\
\text { turbine deck, resulting in a loss of offsite power to } \\
\text { ANO-1. Vibration from the dropped Stator resulted in } \\
\text { the actuation of relays in the ANO-2 switchgear located } \\
\text { adjacent to the train bay, subsequently tripping the } 2 \mathrm{P}-\end{array}$ \\
\hline
\end{tabular}


Table C-1. Multi-unit Initiating Events from 1980-2014

\begin{tabular}{|c|c|c|c|c|c|c|}
\hline \multirow[t]{2}{*}{ Plant } & \multirow[t]{2}{*}{ LER No. } & \multirow[t]{2}{*}{ IE } & \multicolumn{2}{|c|}{ Type of Interaction } & \multirow[t]{2}{*}{$\begin{array}{c}\text { If external, type } \\
\text { correlation }\end{array}$} & \multirow{2}{*}{\begin{tabular}{|l}
\multicolumn{1}{|c}{ Summary of event } \\
32B RCP motor breaker. Because ANO-2 is not \\
designed to operate with less than all four RCPs, an \\
automatic reactor trip occurred as designed.
\end{tabular}} \\
\hline & & & & & & \\
\hline Byron 1 and 2 & $454 / 2007-002$ & $\begin{array}{l}\text { Partial loss of } \\
\text { UHS } \\
\text { Partial loss of } \\
\text { ESW }\end{array}$ & Direct & $\begin{array}{l}\text { Shared } \\
\text { system - } \\
\text { Ultimate } \\
\text { Heat Sink }\end{array}$ & & $\begin{array}{l}\text { The Essential Service Water (ESW) and Ultimate Heat } \\
\text { Sink (UHS) provide a heat sink for the removal of } \\
\text { process and operating heat from safety related } \\
\text { components. The UHS is a common system to Unit } 1 \\
\text { and Unit } 2 \text { and consists of two mechanical draft cooling } \\
\text { towers and basins (i.e., OA and OB) and a water makeup } \\
\text { system. Each tower consists of four separate cooling } \\
\text { cells. The station was in the process of assessing pipe } \\
\text { wall thickness on the riser piping of each cell. The riser } \\
\text { piping of the C cell in the OA tower was being cleaned } \\
\text { of corrosion buildup in order to obtain accurate } \\
\text { ultrasonic wall thickness examinations. During the } \\
\text { course of this cleaning effort, a small hole was created in } \\
\text { the pipe and it started to spray water. The pipe was } \\
\text { declared inoperable. This section of pipe cannot be } \\
\text { isolated from the other cells on the OA tower, } \\
\text { consequently the OA tower (i.e., four cells) was also } \\
\text { declared inoperable. Isolating the OA tower isolates } \\
\text { ESW cooling to key safety equipment, such as the } 1 \mathrm{~A} \\
\text { and } 2 \text { A EDGs. Technical Specification required } \\
\text { shutdown of unit } 1 \text { and unit } 2 \text { because of the UHS pipe } \\
\text { leak common to both units. Causes were determined to } \\
\text { be general and pitting corrosion caused by long term } \\
\text { exposure of the non-protected carbon steel pipe to } \\
\text { misting air/water environment, failure to identify } \\
\text { weaknesses in processes that led to ineffective decision- } \\
\text { making affecting issue prioritization, and less than } \\
\text { adequate procedural guidance related to monitoring } \\
\text { degradation of safety related external pipe corrosion. } \\
\text { Corrective actions include replacement of the degraded } \\
\text { piping and upgrading identified process weaknesses. }\end{array}$ \\
\hline $\begin{array}{l}\text { Prairie Island } 1 \text { and } \\
2\end{array}$ & 282/1996-012 & Strong winds & Direct & $\begin{array}{l}\text { Shared } \\
\text { offsite }\end{array}$ & & $\begin{array}{l}\text { A loss of offsite power to unit } 2 \text { and degraded offsite } \\
\text { power to unit } 1 \text { result in reactor trips of both units. The }\end{array}$ \\
\hline
\end{tabular}


Table C-1. Multi-unit Initiating Events from 1980-2014

\begin{tabular}{|c|c|c|c|c|c|c|}
\hline \multirow[t]{2}{*}{ Plant } & \multirow[t]{2}{*}{ LER No. } & \multirow[t]{2}{*}{ IE } & \multicolumn{2}{|c|}{ Type of Interaction } & \multirow[t]{2}{*}{$\begin{array}{c}\text { If external, type } \\
\text { correlation }\end{array}$} & \multirow[b]{2}{*}{$\begin{array}{l}\text { Summary of event } \\
\text { Blue Lake 345 KV line tripped and stayed out, from a } \\
\text { single phase line to ground fault; both Red Rock } 345 \mathrm{KV} \\
\text { lines \#1 and \#2 tripped and stayed out, from a three } \\
\text { phase fault. Towers on the Red Rock lines and the Blue } \\
\text { Lake line are several miles from one another and about } \\
10 \text { miles north of the plant. The cause of the event was } \\
\text { severe weather with straight-line winds that caused three } \\
\text { out of four 345 KV transmission lines leading into the } \\
\text { Prairie Island substation to fail. The Blue Lake line had } \\
\text { a downed phase while both Red Rock lines had several } \\
\text { failed support structures. }\end{array}$} \\
\hline & & & & power line & & \\
\hline Surry 1 and 2 & 280/2011-001 & $\begin{array}{l}\text { Tornado } \\
\text { induced LOOP }\end{array}$ & Indirect & $\begin{array}{l}\text { Common } \\
\text { location }\end{array}$ & $\begin{array}{l}\text { Source correlated } \\
\text { hazards }\end{array}$ & $\begin{array}{l}\text { From } 50.72 \text { report: Unit } 1 \text { and Unit } 2 \text { experienced an } \\
\text { automatic Reactor Trip from a Loss of Offsite Power, as } \\
\text { a result of a tornado touching down in the station's } \\
\text { switchyard. Unit } 1 \text { reactor tripped as a result of a Loss of } \\
\text { Coolant Flow> P-8 (35\% power), and the Unit } 2 \text { reactor } \\
\text { tripped as a result of a } 500 \mathrm{kV} \text { Leads Differential } \\
\text { Turbine-Generator trip. Both units responded as } \\
\text { designed. }\end{array}$ \\
\hline San Onofre 1 and 2 & 361/1990-003 & Toxic gas & Indirect & $\begin{array}{l}\text { Common } \\
\text { location }\end{array}$ & & $\begin{array}{l}\text { The common Unit } 2 \text { and } 3 \text { control room is designed to } \\
\text { be automatically isolated by the Control Room } \\
\text { Emergency Air Cleanup System (CREACUS) to protect } \\
\text { personnel from potential outside airborne contamination. } \\
\text { CREACUS is started in the isolation mode when the } \\
\text { Toxic Gas Isolation System (TGIS) detects chlorine, } \\
\text { ammonia, or butane (hydrocarbon) gas in the outside air } \\
\text { intake. There are two independent trains of both } \\
\text { CREACUS and TGIS. Each train is actuated by either a } \\
\text { remote manual pushbutton switch (PB), a gas } \\
\text { concentration sensed by any of the gas detectors to be } \\
\text { above the actuation setpoint, or a loss of power. TGIS } \\
\text { starts CREACUS in the isolation mode. Each } \\
\text { CREACUS train then closes all control room air intake } \\
\text { and exhaust pathways, and recirculates the air inside the } \\
\text { control room spaces through high efficiency particulate } \\
\text { air (HEPA) filters and charcoal adsorbers. A TGIS Train }\end{array}$ \\
\hline
\end{tabular}


Table C-1. Multi-unit Initiating Events from 1980-2014

\begin{tabular}{|c|c|c|c|c|c|c|}
\hline \multirow[t]{2}{*}{ Plant } & \multirow[t]{2}{*}{ LER No. } & \multirow[t]{2}{*}{ IE } & \multicolumn{2}{|c|}{ Type of Interaction } & \multirow{2}{*}{$\begin{array}{c}\text { If external, type } \\
\text { correlation }\end{array}$} & \multirow[b]{2}{*}{$\begin{array}{l}\text { Summary of event } \\
\text { B actuation occurred when an operator (utility, licensed) } \\
\text { depressed the reset PB for the Train B chlorine analyzer. } \\
\text { An operation to transfer the power supply for TGIS } \\
\text { Train A had just been completed, which resulted in a } \\
\text { momentary loss of power to the system and an expected } \\
\text { TGIS Train A actuation. The operator was dispatched to } \\
\text { reset TGIS Train A, which involves, in part, depressing } \\
\text { the chlorine analyzer reset PB. Due to inadequate } \\
\text { attention to detail, the operator depressed the reset PB } \\
\text { for Train B rather than for Train A, resulting in the } \\
\text { unplanned TGIS Train B actuation. }\end{array}$} \\
\hline & & & & & & \\
\hline Sequoyah 1 and 2 & 327/1992-027 & Undervoltage & Direct & $\begin{array}{l}\text { Shared } \\
\text { system - } \\
\text { switchyard }\end{array}$ & & $\begin{array}{l}\text { Both units received a reactor trip signal because of } \\
\text { reactor coolant pump bus undervoltage. The } \\
\text { undervoltage condition resulted from an internal fault in } \\
\text { a new switchyard power circuit breaker (PCB) that had } \\
\text { been in service approximately } 11 \text { minutes. The } \\
\text { transmission system network consists of a } 500-\mathrm{kV} \text { and a } \\
161-\mathrm{kV} \text { switchyard. Unit } 1 \text { is connected to the } 500-\mathrm{kV} \\
\text { network and Unit } 2 \text { is connected to the } 161-\mathrm{kV} \text { network. } \\
\text { These two networks are joined by the intertie } \\
\text { transformer. The immediate cause of the event (ESF and } \\
\text { RPS actuations) was an internal fault with the C-phase } \\
\text { of the PCB that was being placed in service. This fault } \\
\text { dropped bus voltages for both units through the intertie } \\
\text { transformer below the undervoltage protection setpoints. } \\
\text { A C-phase to ground fault on the } 500-\mathrm{kV} \text { system caused } \\
\text { both Units } 1 \text { and } 2 \text { to trip. The fault caused the C-phase } \\
\text { voltage in the } 500-\mathrm{kV} \text { switchyard to drop to zero and the } \\
161-\mathrm{kV} \text { switchyard C-phase voltage to dip to } 50 \\
\text { percent. The fault caused the } 161-\mathrm{kV} \text { voltage to dip } \\
\text { because of the intertie transformer being in service at the } \\
\text { time of the fault. The intertie transformer ties the } 161- \\
\mathrm{kV} \text { switchyard to the } 500-\mathrm{kV} \text { switchyard; therefore, the } \\
161-\mathrm{kV} \text { switchyard was supplying power to the fault, } \\
\text { which caused its voltage to dip. Each unit's reactor } \\
\text { protection system responded to the degraded voltage and } \\
\text { tripped. }\end{array}$ \\
\hline
\end{tabular}


Table C-1. Multi-unit Initiating Events from 1980-2014

\begin{tabular}{|c|c|c|c|c|c|c|}
\hline \multirow{2}{*}{$\begin{array}{c}\text { Plant } \\
\text { Sequoyah } 1 \text { and } 2\end{array}$} & \multirow{2}{*}{$\frac{\text { LER No. }}{327 / 2009-003}$} & \multirow{2}{*}{$\begin{array}{l}\text { IE } \\
\begin{array}{l}\text { Undervoltage in } \\
\text { switchyard }\end{array}\end{array}$} & \multicolumn{2}{|c|}{ Type of Interaction } & \multirow[b]{2}{*}{\begin{tabular}{c|c}
$\begin{array}{c}\text { If external, type } \\
\text { correlation }\end{array}$ & \\
& Se \\
tri \\
St \\
pc \\
C \\
& sa \\
en \\
Tr \\
B \\
C \\
fr \\
re \\
fo \\
to \\
in \\
is \\
sv \\
th \\
se
\end{tabular}} & \multirow[b]{2}{*}{$\begin{array}{l}\text { Summary of event } \\
\text { Sequoyah Units } 1 \text { and } 2 \text { received an automatic reactor } \\
\text { trip on RCP buses undervoltage. A loss of Common } \\
\text { Station Service Transformer (CSST) C caused a loss of } \\
\text { power to two unit boards on each unit that feed RCPs. } \\
\text { CSST B continued to supply offsite power to the Train B } \\
\text { safety-related shutdown boards for both units. The } \\
\text { emergency diesel generators started and powered the } \\
\text { Train A safety-related shutdown boards for both units. } \\
\text { Both units were stabilized in hot standby (Mode 3). } \\
\text { CSST C was isolated from CSST D and reenergized } \\
\text { from the switchyard PCBs. Offsite power was then } \\
\text { restored to the Train A safety-related shutdown boards } \\
\text { for both units. The cause of the bus fault was determined } \\
\text { to be degraded bus bar insulation and water intrusion } \\
\text { into the CSST D secondary bus duct. CSST C was } \\
\text { isolated from CSST D and reenergized from the } \\
\text { switchyard power circuit breakers (PCBs). The cause of } \\
\text { the loss of CSST C was determined to be a fault on the } \\
\text { secondary side (6900 volt) bus of CSST D. }\end{array}$} \\
\hline & & & Direct & $\begin{array}{l}\text { Shared } \\
\text { system - } \\
\text { switchyard }\end{array}$ & & \\
\hline
\end{tabular}



APPENDIX D. SINGLE- AND DUAL-UNIT INITIATING EVENTS 

Appendix D. Single- and Dual-Unit IEs

\begin{tabular}{|c|c|c|c|c|}
\hline Type Event & Browns Ferry & Seabrook & Byron/Braidwood & MHTGR \\
\hline Loss of coolant accidents & Loss of coolant accidents & Loss of coolant accidents & Single-unit small LOCA & Primary coolant leaks \\
\hline \multirow[t]{2}{*}{ Internal flooding events } & Turbine building floods & Internal floods & Single-unit SG tube rupture & Small and large SG leaks \\
\hline & Pump room floods & & Multi-unit aux building flood & \\
\hline \multirow[t]{7}{*}{ transients } & General transients & General transients & & $\begin{array}{l}\text { Anticipated transients without } \\
\text { scram (ATWS) }\end{array}$ \\
\hline & & & & Control rod group withdrawal \\
\hline & & & & Loss of heat transport system \\
\hline & Loss of condenser vacuum & $\begin{array}{l}\text { Dual-unit (under certain } \\
\text { conditions) loss of condenser } \\
\text { vacuum }\end{array}$ & & \\
\hline & LOSP to all units & Dual-unit LOOP & $\begin{array}{l}\text { LOOP to both units (grid- } \\
\text { related events) }\end{array}$ & \\
\hline & & & $\begin{array}{l}\text { LOOP to both units (plant- } \\
\text { centered events) }\end{array}$ & \\
\hline & LOSP to one unit & Loss of one dc bus & $\begin{array}{l}\text { LOOP to one unit (plant- } \\
\text { centered events) }\end{array}$ & \\
\hline \multirow[t]{10}{*}{ Loss of support system } & Loss of plant control air & & & \\
\hline & Loss of $500-\mathrm{kV}$ grid to plant & & & LOOP \\
\hline & Loss of 500-kV grid to unit & & & \\
\hline & Loss of raw cooling water & $\begin{array}{l}\text { Loss of primary component } \\
\text { cooling water }\end{array}$ & $\begin{array}{l}\text { Single-unit loss of component } \\
\text { cooling water }\end{array}$ & \\
\hline & & & $\begin{array}{l}\text { Dual-unit loss of component } \\
\text { cooling water }\end{array}$ & \\
\hline & Loss of unit preferred power & & & \\
\hline & Loss of I\&C bus & $\begin{array}{l}\text { Dual-unit (under certain } \\
\text { conditions) turbine missile }\end{array}$ & & \\
\hline & $\begin{array}{l}\text { Loss of reactor building closed } \\
\text { cooling water }\end{array}$ & $\begin{array}{l}\text { Dual-unit (under certain } \\
\text { conditions) total loss of service } \\
\text { water }\end{array}$ & Single-unit loss of heat sink & \\
\hline & Loss of HVAC & & & \\
\hline & Loss of chilled water & & dual-unit loss of essential & \\
\hline
\end{tabular}


Appendix D. Single- and Dual-Unit IEs

\begin{tabular}{|c|c|c|c|c|}
\hline Type Event & Browns Ferry & Seabrook & Byron/Braidwood & MHTGR \\
\hline & & & service water & \\
\hline & & & $\begin{array}{l}\text { single-unit loss of essential } \\
\text { service water }\end{array}$ & \\
\hline \multirow[t]{5}{*}{ External events } & & Internal fires & & \\
\hline & & Aircraft crashes & & \\
\hline & & Dual-unit seismic event & & earthquakes \\
\hline & & $\begin{array}{l}\text { Dual-unit tornado and wind } \\
\text { events }\end{array}$ & & \\
\hline & & $\begin{array}{l}\text { Dual-unit external flooding } \\
\text { event }\end{array}$ & & \\
\hline
\end{tabular}


APPENDIX E. GENERIC SAFETY ISSUES WITH MULTI-UNIT IMPLICATIONS 

Appendix E. Generic Safety Issues (GSIs) with multi-unit implications

\begin{tabular}{|c|c|c|}
\hline $\begin{array}{c}\text { Generic Safety } \\
\text { Issue (GSI) }\end{array}$ & Title & Description \\
\hline GSI 43 & $\begin{array}{l}\text { Reliability of } \\
\text { Air Systems }\end{array}$ & $\begin{array}{l}\text { This issue was initiated in response to an immediate action memorandum issued by the Office for Analysis and Evaluation of } \\
\text { Operational Data (AEOD) in September } 1981 \text { regarding desiccant contamination of instrument air lines. The Office of } \\
\text { Nuclear Reactor Regulation (NRR) responded to the AEOD memorandum by establishing a working group to determine the } \\
\text { generic implications of air system contamination and to develop recommendations accordingly. The AEOD memorandum was } \\
\text { prompted by an incident at Rancho Seco where the slow closure of a containment isolation valve resulted from the presence of } \\
\text { desiccant particles in the valve operator. Desiccant contamination of the plant instrument air system (IAS) was also found to } \\
\text { be one of the contributing causes of the loss of the salt water cooling system at San Onofre in March 1980; this incident } \\
\text { resulted in Issue 44, "Failure of Saltwater Cooling System." Since the only new generic concern to be found in the evaluation } \\
\text { of the San Onofre event was the common cause failure of safety-related components due to contamination of the IAS, Issue } 44 \\
\text { was combined with Issue } 43 \text {. } \\
\text { A loss of instrument air was evaluated as an IE but not as a shared system. Therefore, this GSI is not applicable to this review. }\end{array}$ \\
\hline GSI 44 & $\begin{array}{l}\text { Failure of } \\
\text { Saltwater } \\
\text { Cooling } \\
\text { System }\end{array}$ & $\begin{array}{l}\text { While operating at } 100 \% \text { power on March 10, 1980, San Onofre Unit } 1 \text { experienced a complete loss of the salt water cooling } \\
\text { system. The event involved an unlikely triple failure and desiccant contamination of the instrument air system was found to be } \\
\text { the major contributing cause of one of the failures. }\end{array}$ \\
\hline & & $\begin{array}{l}\text { After issuance of the case study (AEOD/C204) } 1055 \text { on the San Onofre event, AEOD recommended } 499 \text { further review and/or } \\
\text { requirements in four specific areas: (1) single failure vulnerability of cooling systems; (2) inservice test programs; (3) } \\
\text { contamination of plant air systems; and (4) plant technical specifications. }\end{array}$ \\
\hline & & $\begin{array}{l}\text { The NRR response to AEOD indicated that two of the four recommendations had already been implemented, i.e., the single } \\
\text { failure analysis was included in SEP Topic IX-3 and inservice testing was within the scope of the review of licensee inservice } \\
\text { testing (IST) programs. With regard to the AEOD recommendation on plant technical specifications, NRR determined that the } \\
\text { existing LCO for salt water cooling systems in the standard technical specifications was adequate and no further action was } \\
\text { contemplated. Thus, the only remaining generic concern of this issue was the safety system vulnerability to common cause } \\
\text { failures from contamination of the instrument air system. A specific issue (Issue } 43 \text { ) was previously identified for the generic } \\
\text { review and resolution of concerns for contamination of instrument air systems. Thus, the remaining generic concern of Issue } \\
44 \text { was determined to be covered in Issue } 43 \text {. }\end{array}$ \\
\hline GSI 45 & $\begin{array}{l}\text { Inoperability } \\
\text { of } \\
\text { Instrumentatio } \\
\text { n due to Cold } \\
\text { Weather }\end{array}$ & $\begin{array}{l}\text { Concerns for inoperability of instrumentation due to extreme cold weather were raised502 by AEOD after an event at } \\
\text { Arkansas Nuclear One, Unit } 2 \text { (ANO-2) in which all four refueling water storage tank (RWST) instrumentation channels were } \\
\text { lost when the level transmitters froze. The system heat-tracing circuit was de-energized because the main line fuse was } \\
\text { removed. This situation would have prevented the automatic change-over of the ECC from injection to recirculation mode } \\
\text { under LOCA conditions, i.e., loss of safety function. Prior to the ANO-2 event, IE Bulletin No. 79-24501 was issued after } \\
\text { LERs revealed many events involving frozen instrument, sampling, and processing lines. All licensees and CP holders were } \\
\text { requested to review their plants to determine that adequate protective measures had been taken to assure that safety-related } \\
\text { process, instrument, and sampling lines do not freeze during extremely cold weather. AEOD requested that OIE issue a }\end{array}$ \\
\hline
\end{tabular}


Appendix E. Generic Safety Issues (GSIs) with multi-unit implications

\begin{tabular}{|c|c|c|}
\hline $\begin{array}{l}\text { Generic Safety } \\
\text { Issue (GSI) }\end{array}$ & Title & Description \\
\hline & & $\begin{array}{l}\text { supplement to Bulletin 79-24501 and that NRR address the adequacy of protective measures for freezing of safety-related } \\
\text { instrument lines in the review of OLs. } \\
\text { In an August 14, } 1981 \text { memorandum to AEOD503 NRR advised that a BTP on freeze protection of safety-related instrument } \\
\text { lines was being developed and would be included in the appropriate SRP11 Section following its review and approval. NRR } \\
\text { further advised that OIE proposed to amend the Inspection and Enforcement Manual247 to include a module which would set } \\
\text { forth procedures for inspection of systems and measures for protection against cold weather. This inspection module would } \\
\text { require that regional inspectors perform plant site visits prior to the beginning of the cold season to verify the condition of } \\
\text { heat-tracing systems and measures taken to protect plant equipment from cold weather conditions. } \\
\text { An amendment to the Inspection and Enforcement Manual (Procedure No. } 71714 \text { ) } 247 \text { was issued by OIE on January 1, 1982, } \\
\text { thus completing the OIE portion of the resolution of this issue. Acceptance criteria for the design of protective measures } \\
\text { against freezing in instrument lines of safety-related systems were included in Draft504 Regulatory Guide 1.151, "Instrument } \\
\text { Sensing Lines," and further work on a BTP was terminated. The Draft Regulatory Guide was issued for comment in March, } \\
\text { 1982. Comments were collected and dispositioned and the Regulatory Guide505 was published in July, 1983. Notice of the } \\
\text { issuance of Regulatory Guide } 1.151505 \text { was published in the Federal Register506 on August } 8,1983 \text {. Implementation of the } \\
\text { Guide was limited to all CPs issued after September 1, 1983. However, other licensees or applicants could adopt the use of the } \\
\text { Guide on a voluntary basis. As stated in the value/impact statement for the Guide, no backfitting of requirements for freeze } \\
\text { protection and alarms was to be accomplished other than those changes effected by IE Bulletin 79-24501 (and the inspection } \\
\text { requirements added to the OIE Inspection Manual). }\end{array}$ \\
\hline GSI 102 & $\begin{array}{l}\text { Human Error } \\
\text { Wrong Unit or } \\
\text { Wrong Train }\end{array}$ & $\begin{array}{l}\text { Human errors in maintenance and testing operations can be major contributors to loss of safety system events. Safety } \\
\text { functions can be inadvertently defeated by human errors involving the wrong unit, wrong train, or wrong system. } \\
\text { IN 87-25 was issued to increase attention in this area. } \\
\text { Interestingly, NUREG-1192, An Investigation of the Contributors to Wrong Unit or Wrong Train Events, states that } \\
\text { The three main reasons why wrong unit/wrong train errors resulted from procedures are: } 1 \text { ) the procedure was generic, that is, } \\
\text { it applied to both units, multiple trains or multiple plant conditions, 2) the procedure contained flaws from a human factors } \\
\text { viewpoint (other than applicability to multiple units, trains or conditions) in the way the procedure was written, and 3) plant } \\
\text { personnel needed to generate valve and switch numbers each time a procedure was used. } \\
\text { Because the procedures are most likely to be the same for each unit at a multi-unit site, a flawed procedure would also be the } \\
\text { same for each unit. } \\
\text { For this to be an IE, the flawed procedure would have to be implemented at the same time on both units; this is deemed to be } \\
\text { unlikely. } \\
\text { The review of this GSI provides the following important insights: } \\
\text { - Common or dependent equipment and operator actions between multiple reactors should be considered }\end{array}$ \\
\hline
\end{tabular}


Appendix E. Generic Safety Issues (GSIs) with multi-unit implications

\begin{tabular}{|c|c|c|}
\hline $\begin{array}{c}\text { Generic Safety } \\
\text { Issue (GSI) }\end{array}$ & Title & Description \\
\hline GSI 130 & $\begin{array}{l}\text { ESW pump } \\
\text { failures at } \\
\text { Multiplant } \\
\text { Sites }\end{array}$ & $\begin{array}{l}\text { GSI Issue 130, Essential Service Water Pump Failures at Multi-plant Sites, was identified when the staff found the Byron Unit } \\
1 \text { vulnerable to core-melt sequences in the absence of the availability of Byron Unit } 2 \text {. Although Unit } 2 \text { was under } \\
\text { construction, a safety evaluation by the licensee determined that the success criteria for the multi-plant configurations with } 2 \\
\text { ESW pumps/plant with crosstie capabilities assumed that one ESW pump can provide adequate cooling to shut down the } \\
\text { operating plant through the crosstie connections, should the need arise. However, with only one ESW pump operating, the } \\
\text { other three pumps may not be available in sufficient time if the operating pump fails. The results are applicable to one plant in } \\
\text { normal operation and the second plant already in the shutdown or refueling modes of operation. Hence, this GSI shows that } \\
\text { multi-unit vulnerabilities may exist even when one of the plants is not operational or in a shutdown state. The review of this } \\
\text { GSI provides the following important insights: }\end{array}$ \\
\hline & & $\begin{array}{l}\text { 1. Cross-ties between units can be a significant contributor to lessening risks but can also be large contributors to risk } \\
\text { when unavailable (this affects the recovery factors at multi-unit sites) } \\
\text { 2. All operating states must be considered and both units need not be in the same state } \\
\text { 3. Numerous definitions exist for defining a multi-unit IE. These definitions should be reviewed because the event } \\
\text { discussed in GSI 130, which was applicable to } 7 \text { sites/14 units does not meet the most common definition. } \\
\text { 4. some systems may not be available because technical specifications allow more equipment to be inoperable during } \\
\text { low power and shutdown (LPSD) conditions than at power, } \\
\text { 5. LPSD initiating events (by definition) impact the operable train of decay heat removal systems, and } \\
\text { 6. human errors are more likely because of the increase in activity during shutdown (e.g., unusual equipment line-ups } \\
\text { 7. In make mistakes more likely). } \\
\text { construction-induced IEs at the other unit, which may be at-power operations or shutdown. }\end{array}$ \\
\hline GSI 143 & $\begin{array}{l}\text { Availability of } \\
\text { Chilled Water } \\
\text { Systems and } \\
\text { Room Cooling }\end{array}$ & $\begin{array}{l}\text { HVAC systems for single units were evaluated in GSI Issue 143; HVAC systems at multi-unit plants were evaluated in GSI } \\
\text { Issue } 162 .\end{array}$ \\
\hline GSI 153 & $\begin{array}{l}\text { Loss of } \\
\text { Essential } \\
\text { Service Water } \\
\text { in LWRs }\end{array}$ & $\begin{array}{l}\text { The reliability of essential service water (ESW) systems and related problems have been an ongoing staff concern which has } \\
\text { been documented in NUREG/CR-2797,1334 IE Bulletins 80-24201 and 81-03,207 Generic Letter No. 89-13,1259 and Issues } \\
51,65 \text {, and 130. In a comprehensive NRC review and evaluation of operating experience related to service water systems } \\
\text { (NUREG-1275, Volume 3),1079 a total of } 980 \text { operational events involving the ESW system were identified, of which, } 12 \\
\text { resulted in complete loss of the ESW system. The causes of failure and degradation included: (1) various fouling mechanisms } \\
\text { (sediment deposition, biofouling, corrosion and erosion, foreign material and debris intrusion); (2) ice effects; (3) single } \\
\text { failures and other design deficiencies; (4) flooding; (5) multiple equipment failures; and (6) personnel and procedural errors. } \\
\\
\text { In the resolution of Issue 130, the staff surveyed seven multiplant sites and found that loss of the ESW system could be a } \\
\text { significant contributor to CDF. The generic safety insights gained from this study supported previous perceptions that ESW } \\
\text { system configurations at other multiplant and single plant sites may also be significant contributors to plant risk and should }\end{array}$ \\
\hline
\end{tabular}


Appendix E. Generic Safety Issues (GSIs) with multi-unit implications

\begin{tabular}{|c|c|c|}
\hline $\begin{array}{c}\text { Generic Safety } \\
\text { Issue (GSI) }\end{array}$ & Title & Description \\
\hline & & $\begin{array}{l}\text { also be evaluated. As a result, this issue was identified } 1280 \text { by the Department of Scientific and Industrial Research } \\
\text { (DSIR)/RES to address all potential causes of ESW system unavailability, except those that had been resolved by } \\
\text { implementation of the requirements stated in Generic Letter No. 89-13.1259 } \\
\text { At each plant, the ESW system supplies cooling water to transfer heat from various safety-related and non-safety-related } \\
\text { systems and equipment to the ultimate heat sink. The ESW system is needed in every phase of plant operations and, under } \\
\text { accident conditions, supplies adequate cooling water to systems and components that are important to safe plant shutdown or } \\
\text { to mitigate the consequences of the accident. Under normal operating conditions, the ESW system provides component and } \\
\text { room cooling (mainly via the component cooling water system). During shutdowns, it also ensures that the residual heat is } \\
\text { removed from the reactor core. The ESW system may also supply makeup water to fire protection systems, cooling towers, } \\
\text { and water treatment systems at a plant. } \\
\text { The design and operational characteristics of the ESW system are different for PWRs and BWRs and also differ significantly } \\
\text { from plant to plant within each of these reactor types. The success criteria associated with the functions of an ESW system are } \\
\text { also plant-specific. A complete loss of the ESW system could potentially lead to a core-melt accident, posing a significant risk } \\
\text { to the public. This issue affected all plants not covered in the resolution of Issue } 130 \text { and included consideration of Issue B-32. } \\
\\
\text { The design of the ESW system varies substantially from plant to plant and the ESW system is highly dependent on the NSSS. } \\
\text { As a result, generic solutions (if needed) are likely to be different for PWRs and BWRs. The possible solutions are: (1) } \\
\text { installation of a redundant intake structure including a service water pump; (2) hardware changes of the ESW system; (3) } \\
\text { installation of a dedicated RCP seal cooling system; or (4) changes to TS or operational procedures. These potential } \\
\text { improvements were considered for the seven multiplant sites covered in the scope of Issue 130; however, these options will } \\
\text { now be evaluated for the remaining LWRs (65 PWRs and } 39 \text { BWRs). }\end{array}$ \\
\hline GSI 156 & \begin{tabular}{|l|} 
Systematic \\
Evaluation \\
Program (SEP) \\
-156.3 .8$, \\
Shared \\
systems
\end{tabular} & $\begin{array}{l}\text { The sharing of the ESFS for a multi-unit plant, including onsite emergency power systems and service systems, can result in a } \\
\text { reduction of the number and capacity of onsite systems to below that which is needed to bring either unit to a safe shutdown } \\
\text { condition, or to mitigate the consequences of an accident. Shared systems for multiple unit stations should include equipment } \\
\text { powered from each of the units involved. } \\
\text { The safety concerns associated with systems that are shared by two or more units at multi-unit sites have been previously } \\
\text { identified by the NRC staff. The most important contributors to core damage probability at these sites have been determined to } \\
\text { be air, cooling water, and electric power systems. NRC concluded that these systems have been adequately addressed in Issues } \\
43,130,153 \text {, and A- } 44 \text {. }\end{array}$ \\
\hline
\end{tabular}


Appendix E. Generic Safety Issues (GSIs) with multi-unit implications

\begin{tabular}{|l|l|l|}
\hline $\begin{array}{ll}\text { Generic Safety } \\
\text { Issue (GSI) }\end{array}$ & \multicolumn{1}{|c|}{ Title } & \multicolumn{1}{c|}{ Description } \\
\hline GSI 162 & $\begin{array}{l}\text { Inadequate } \\
\text { Tech Specs at } \\
\text { Multiplant } \\
\text { Sites }\end{array}$ & $\begin{array}{l}\text { An inspection at Zion identified the potential for some additional shared systems to have an inadequate number of available } \\
\text { components or inadequate flow rates when one unit is shut down and the other unit is operating. } \\
\text { NRR identified the following systems as having the potential for inadequate TS when they are shared: (1) HVAC systems for } \\
\text { shared control room areas and switchgear rooms; (2) onsite ac and dc systems; and (3) the CCW system. } \\
\text { This review, along with a review of applicable Bulletins, Information Notices, and Generic Letters, resulted in the following } \\
\text { observations: } \\
\text { The CCW system is generally not shared. (The CCW system is shared at Surry 1 \& 2, Zion 1 \& 2, and D. C. Cook 1 \& 2) } \\
\text { The HVAC system for common control room areas is required to be operable in all modes so that the operating mode of one } \\
\text { unit does not affect the operability of the other unit's HVAC system. Control room HVAC systems were reviewed under Issue } \\
\text { 143. Consequently, it was concluded that the HVAC system for common control room areas did not warrant additional } \\
\text { generic review. } \\
\text { The design of HVAC systems servicing non-control room areas (e.g., switchgear rooms) is plant-specific. } \\
\text { Onsite ac and dc systems for multi-plant sites are generally physically and electrically separated and redundant and are rarely } \\
\text { shared between units. } \\
\text { The review of this GSI provides the following important insights: } \\
\text { Common or dependent equipment and operator actions between multiple reactors should be considered } \\
\text { All operating states must be considered and both units need not be in the same state }\end{array}$ \\
\hline
\end{tabular}


Appendix E. Generic Safety Issues (GSIs) with multi-unit implications

\begin{tabular}{|c|c|c|}
\hline $\begin{array}{c}\text { Generic Safety } \\
\text { Issue (GSI) }\end{array}$ & Title & Description \\
\hline $\begin{array}{l}\text { GSI A-17 (TMI } \\
\text { Action Plan) }\end{array}$ & $\begin{array}{l}\text { Systems } \\
\text { Interactions }\end{array}$ & 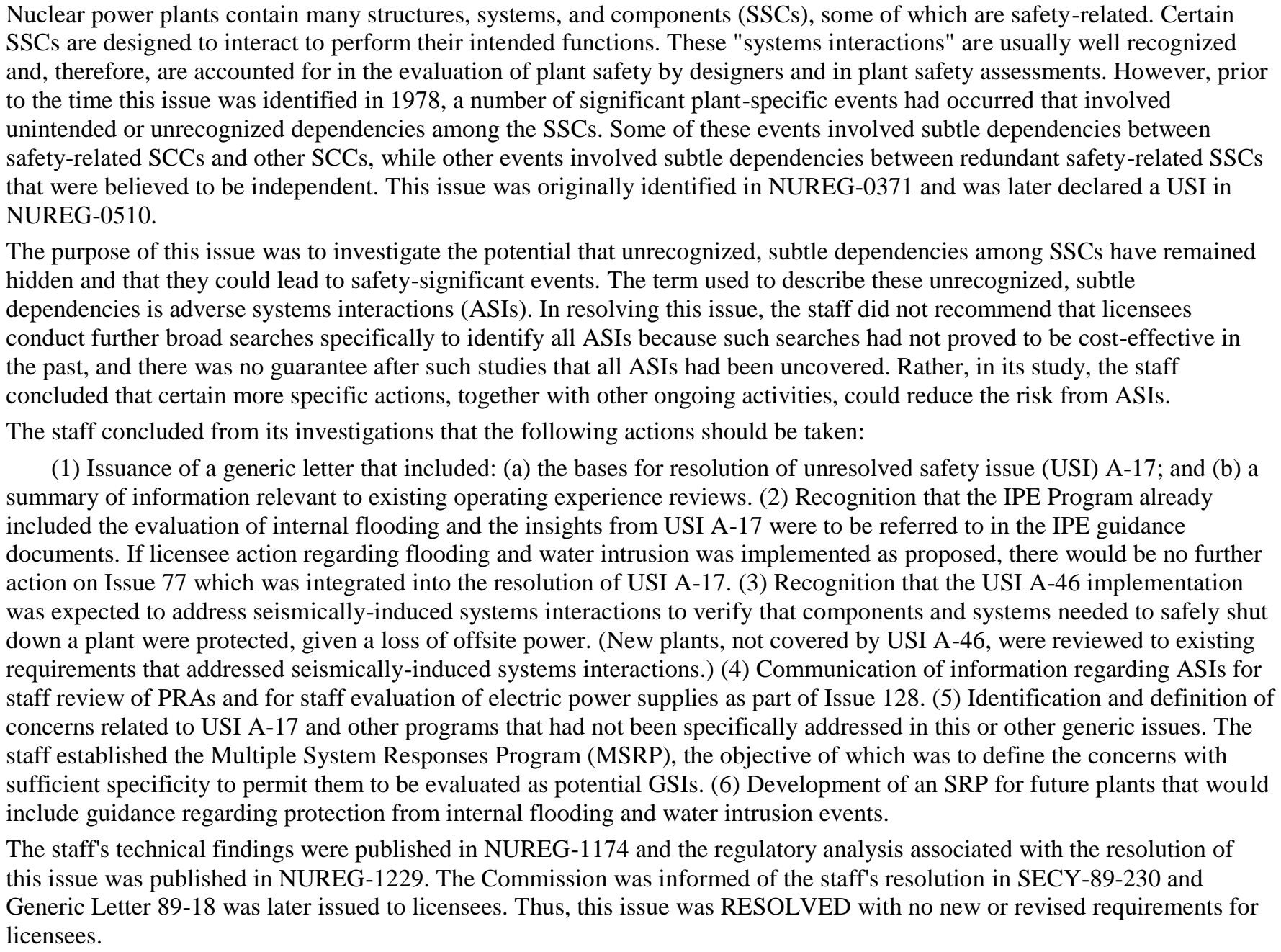 \\
\hline
\end{tabular}


Appendix E. Generic Safety Issues (GSIs) with multi-unit implications

\begin{tabular}{|c|c|c|}
\hline $\begin{array}{c}\text { Generic Safety } \\
\text { Issue (GSI) }\end{array}$ & Title & Description \\
\hline \multirow[t]{2}{*}{ GSI Item A-44 } & \multirow[t]{2}{*}{\begin{tabular}{|l} 
Station \\
Blackout
\end{tabular}} & $\begin{array}{l}\text { GSI Item A-44 did not address dual- or multi-unit coupling of ac power; however, the references did. Insights from this review } \\
\text { (including references NUREG-1032 and RG 1.155) are that offsite power can be lost to multi-units simultaneously. Recovery } \\
\text { actions via diesel generators depend on the plant. }\end{array}$ \\
\hline & & $\begin{array}{l}\text { Emergency AC power systems typically consist of two diesel generators, either one of which is sufficient to meet AC power } \\
\text { load requirements for a design-basis accident. This configuration has been designated by its success criterion: one out of two } \\
\text { or more simply } 1 / 2 \text {. In some cases, three or four or more diesel generators are used at single-unit sites, and in others, diesel } \\
\text { generators are shared at multi-unit sites. These systems also can be described by their success criteria, or number of diesel } \\
\text { generators required per number provided. }\end{array}$ \\
\hline \multirow[t]{4}{*}{ COL-ISG-022 } & \multirow[t]{4}{*}{$\begin{array}{l}\text { ISG on impact } \\
\text { of construction } \\
\text { (ML11263004 } \\
4 \text { ) }\end{array}$} & $\begin{array}{l}\text { 10CFR52.79(a)(31) addresses the review of an evaluation of potential hazards to the SSCs important to safety of the operating } \\
\text { units resulting from construction activities, as well as a description of the managerial and administrative controls to be used to } \\
\text { provide assurance that the limiting conditions for operation are not exceeded as a result of construction activities at multi-unit } \\
\text { sites. Because the requirements of } 10 \text { CFR 52.79(a)(31) are intended to apply both to construction activities and subsequent } \\
\text { operation of the new unit(s) analogous to the provisions of } 10 \text { CFR 50.34(a)(11) and } 10 \text { CFR 50.34(b)(6)(vii) for units } \\
\text { licensed under the Part } 50 \text { regime. The requirement in } 10 \text { CFR 52.79(a)(31) can be viewed as having two subparts: }\end{array}$ \\
\hline & & $\begin{array}{l}\text { 1. The COL applicant must evaluate the potential hazards from constructing new plants on SSCs important to safety for } \\
\text { existing operating plants that are located at the site. } \\
\text { 2. The COL applicant must evaluate the potential hazards from constructing new plants on SSCs important to safety for } \\
\text { newly constructed plants that begin operation at the site. }\end{array}$ \\
\hline & & $\begin{array}{l}\text { The underlying requirements contained in } 10 \mathrm{CFR} 52.79(\mathrm{a})(31) \text { for } \mathrm{COL} \text { applicants to evaluate the potential hazards to SSCs } \\
\text { important to safety for operating units from the construction activities associated with new units are not new. The requirement } \\
\text { for applicants for OLs to address potential hazards due to construction activities has been included in } \S 50.34(\mathrm{a})(11) \text { and } \\
50.34(\mathrm{~b})(6)(\text { vii) for over } 30 \text { years. }\end{array}$ \\
\hline & & $\begin{array}{l}\text { The Commission approved the rulemaking noting that existing regulations covered the other (non-construction) activities, but } \\
\text { since no regulation specifically addressed multi-unit sites, a specific regulation to do so was prudent. The Commission further } \\
\text { noted that the new rule would divide responsibilities between the applicant for the new unit and the licensee for the operating } \\
\text { unit. }\end{array}$ \\
\hline $\begin{array}{l}\text { Candidate } \\
\text { Generic Issue }\end{array}$ & $\begin{array}{l}\text { Multi-unit core } \\
\text { damage events }\end{array}$ & $\begin{array}{l}\text { Accident sequences have been identified which potentially result in core damage accident sequences occurring in multiple } \\
\text { units of a multiple unit site. Multiple unit core damage scenarios generally results from an initiator that can fail similar } \\
\text { equipment in each unit (e.g. a seismic event or an internal flooding event) or are a result of a high degree of sharing of systems } \\
\text { among the units such as sharing all diesel generators. }\end{array}$ \\
\hline
\end{tabular}


Appendix E. Generic Safety Issues (GSIs) with multi-unit implications

\begin{tabular}{|l|l|l|}
\hline $\begin{array}{c}\text { Generic Safety } \\
\text { Issue (GSI) }\end{array}$ & Title & \multicolumn{1}{c|}{ Description } \\
\hline & & $\begin{array}{l}\text { During the sequence identification and selection process for the SOARCA project for the Surry and Peach Bottom plants the } \\
\text { SOARCA staff have identified scenarios in which both units at each plant would be expected to experience accident sequence } \\
\text { progression pathways leading to core damage as a result of the initiating event. These scenarios include internal flooding } \\
\text { (turbine building flood), long term station blackout, and seismic initiated long term station blackout. } \\
\text { NUREG-1437 (Appendix G) for Brunswick Units 1 and 2 (USNRC 2006) indicates that “.... dual-unit SBO accounts for 37 } \\
\text { percent of the total CDF compared with only 2.3 percent from single-unit SBO ...” } \\
\text { The Browns Ferry Supplemental EIS for license renewal also indicated that multi-unit core damage events for station blackout } \\
\text { scenarios were significant. } \\
\text { Consideration of multi-unit operation in a PRA also may impact the estimated CDF for individual units. The Browns Ferry } \\
\text { Multiple Unit PSA (1995) indicates that the mean core damage frequency of Unit 2 is a factor of 4 greater with all three units } \\
\text { operating compared to only Unit 2 operating. }\end{array}$ \\
\hline
\end{tabular}




\section{APPENDIX F. REGULATORY GUIDES WITH MULTI-UNIT}

IMPLICATIONS 



\section{Appendix F. Regulatory Guides (RGs) with multi-unit implications}

\begin{tabular}{|c|c|c|}
\hline RG & Title & Description \\
\hline 1.32 & $\begin{array}{l}\text { Criteria for Power } \\
\text { Systems for Nuclear } \\
\text { Power Plants }\end{array}$ & 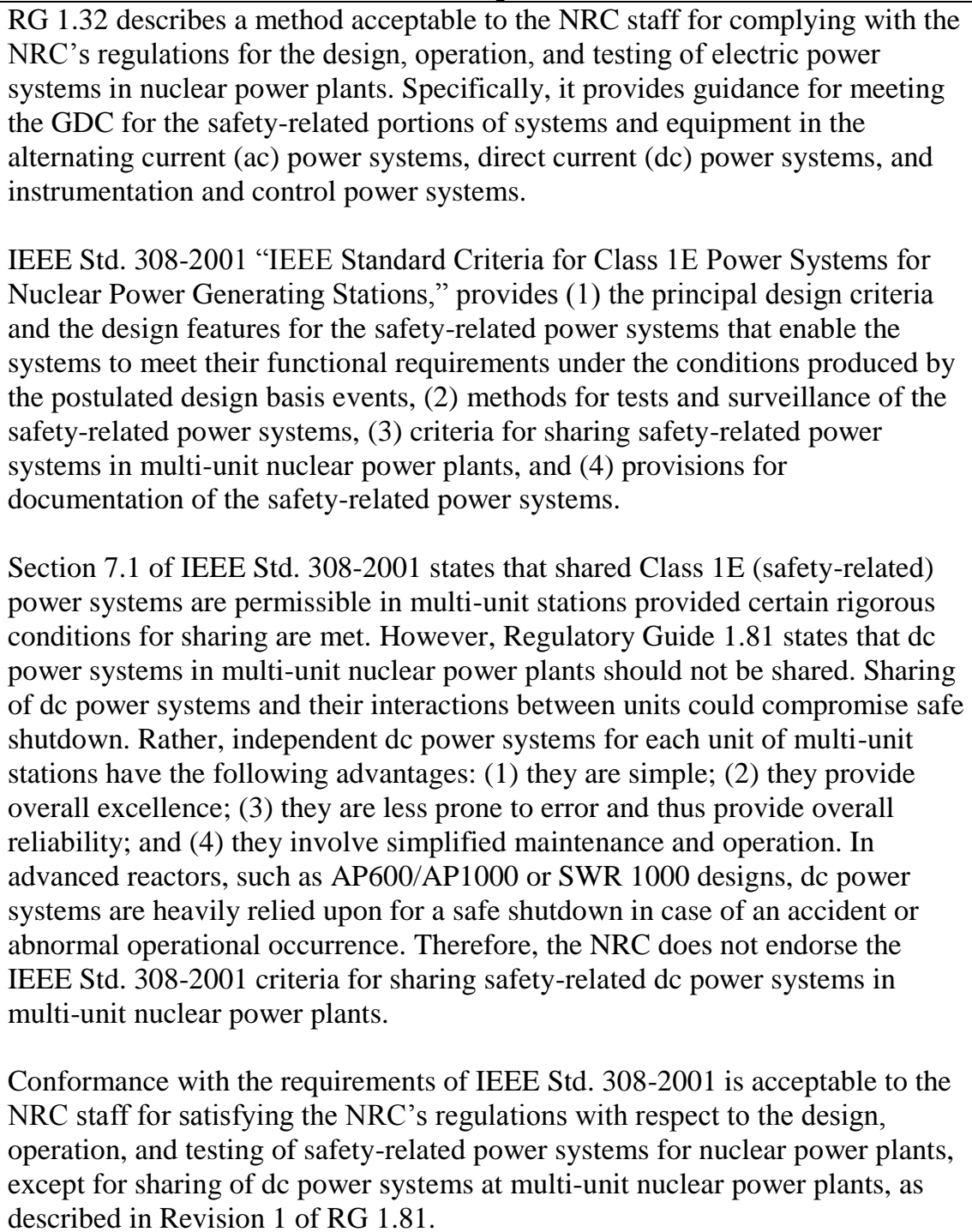 \\
\hline 1.81 & $\begin{array}{l}\text { Shared Electric Systems } \\
\text { for Multi-unit NPPs }\end{array}$ & $\begin{array}{l}\text { To assure ensure that the requirements of GDC } 5 \text { are satisfied, the structures, } \\
\text { systems, and components of the preferred power systems are examined to } \\
\text { identify any that are shared between units of a multi-unit station. These are } \\
\text { reviewed to ascertain that they have sufficient capacity and capability of } \\
\text { performing all required safety functions in the event of an accident in one unit, } \\
\text { with a simultaneous orderly shutdown and cooldown of the remaining units. } \\
\text { With respect to offsite electric power, the review of the design criteria is to } \\
\text { establish that the capacity and capability of incoming lines, power sources, and } \\
\text { transformers for each required circuit have margin to achieve this. Spurious or } \\
\text { false accident signals should not overload these circuits. } \\
\text { RGs are guidance to licensees for meeting the regulations. However, a periodic } \\
\text { review of RG } 1.81 \text { [7] noted that the guidance in RG } 1.81 \text { is not fully consistent } \\
\text { with the current requirements of } 10 \text { CFR 50.55a(h), "Protection and Safety }\end{array}$ \\
\hline
\end{tabular}

7 Letter from T. H. Boyce, Office of NRR, U.S. NRC to M. J. Case, Office of RES, U.S. NRC, Results of Periodic Review of Regulatory Guide (RG) 1.81, Enclosure "Periodic Review of RG 1.81," Feb. 20, 2014. (ML14035A429) 


\section{Appendix F. Regulatory Guides (RGs) with multi-unit implications}

\begin{tabular}{|c|c|l|}
\hline RG & \multicolumn{1}{|c|}{ Title } & \multicolumn{1}{c|}{ Description } \\
\hline & $\begin{array}{l}\text { Systems." The RG recommends separate and independent onsite emergency and } \\
\text { shutdown electric systems for multi-unit nuclear power plants. It further } \\
\text { recommends that onsite emergency electric power systems should not be shared } \\
\text { between units and should be independent to minimize undesirable interactions } \\
\text { between units. These recommendations do not agree with the current } \\
\text { requirements in 10 CFR 50.55a(h), which states that applications for } \\
\text { construction permits filed after May 13, 1999, must meet the requirements of } \\
\text { IEEE Std. 603-1991, "IEEE Standard Criteria for Safety Systems for Nuclear } \\
\text { Power Generating Stations" which allows the sharing of electrical power } \\
\text { systems between units as long as the shared components follow the guidance in } \\
\text { IEEE Std. 308- 1980. IEEE Std. 308-1980 states that Class 1E power systems } \\
\text { can be shared between units provided that the ability to simultaneously perform } \\
\text { required safety functions is not impaired. }\end{array}$ \\
\hline
\end{tabular}


APPENDIX G. OTHER NRC STUDIES WITH MULTI-UNIT IMPLICATIONS 

Appendix G. Other NRC studies with multi-unit implications

\begin{tabular}{|c|c|c|}
\hline Number & Title & Description \\
\hline $\begin{array}{l}\text { NUREG/CP- } \\
\text { 0149, Vol. } 2\end{array}$ & $\begin{array}{l}\text { Proceedings } \\
\text { of the U.S. } \\
\text { Nuclear } \\
\text { Regulatory } \\
\text { Commission } \\
\text { Twenty-Third } \\
\text { Water } \\
\text { Reactor } \\
\text { Safety } \\
\text { Information } \\
\text { Meeting }\end{array}$ & $\begin{array}{l}\text { NUREG-1150 Perspective: Properly designed crossties between systems can substantially } \\
\text { decrease the core damage frequency } \\
\text { Many plants can crosstie at least a few important systems. Crossties allow failures within } \\
\text { systems to be circumvented. The crossties can be fairly simple connections among } \\
\text { parallel trains of a system or complex connections among different units of a multiunit } \\
\text { site. Crossties typically involve systems such as electric power, auxiliary feedwater, } \\
\text { service water, and various water storage tanks. These crossties have lowered the CDF at } \\
\text { many plants. Since there is a potential for incorrect cross connecting, proper } \\
\text { administrative control is very important. }\end{array}$ \\
\hline $\begin{array}{l}\text { NUREG- } \\
1843\end{array}$ & $\begin{array}{l}\text { Safety } \\
\text { Evaluation } \\
\text { Report } \\
\text { Related to the } \\
\text { License } \\
\text { Renewal of } \\
\text { the Browns } \\
\text { Ferry Nuclear } \\
\text { Plant, Units } \\
1,2 \text {, and } 3\end{array}$ & $\begin{array}{l}\text { Cross-connections with the fuel pool cooling system allow the RHR heat exchangers to } \\
\text { supplement heat removal and provide a permanent source of makeup water for the spent } \\
\text { fuel pool. }\end{array}$ \\
\hline $\begin{array}{l}\text { NUREG/CR- } \\
6890 \text {, Vol. } 1\end{array}$ & $\begin{array}{l}\text { Reevaluation } \\
\text { of Station } \\
\text { Blackout } \\
\text { Risk at } \\
\text { Nuclear } \\
\text { Power Plants } \\
\text { Analysis of } \\
\text { Loss of } \\
\text { Offsite Power } \\
\text { Events: 1986- } \\
2004\end{array}$ & $\begin{array}{l}\text { As mentioned earlier, it is difficult to identify and adequately treat dependencies that exist } \\
\text { between systems at multi-unit sites, particularly those with highly convoluted support } \\
\text { system dependencies (systems and subsystems shared by different units). There are } \\
\text { initiating events that may or may not impact two or more units at the same site, human } \\
\text { action dependencies in deciding how to deploy equipment and personnel to support all } \\
\text { plants on the site, and the possibility of accidents involving two or more reactors. The risk } \\
\text { metrics that are being employed such as CDF and LERF are being developed either for } \\
\text { one representative reactor unit, or for each reactor independently. Multi-unit reactor } \\
\text { accident consequences are currently being ignored and there is no consideration that the } \\
\text { frequency of core damage per site year will be increased due to independent contributions } \\
\text { from each reactor at the site. } \\
\text { Among the } 135 \text { LOOP plant-level events considered in this study for frequency and } \\
\text { duration analyses (148 total events, minus } 10 \text { LOOP-NTs, and with the LaCrosse and two } \\
\text { Pilgrim salt spray LOOPs removed), there were } 12 \text { occurrences involving more than one } \\
\text { plant at a site resulting from the same event (over a period of } 24 \text { h). The LaCrosse event } \\
\text { was removed because of atypical plant design, while the two Pilgrim events were } \\
\text { removed because plant modifications were made to minimize salt spray impacts. These } \\
\text { events are listed in chronological order in Table 6-3. Eleven involved both plants at two- } \\
\text { plant sites, while one (Palo Verde on June } 14,2004 \text { ) involved all three plants at the site. }\end{array}$ \\
\hline
\end{tabular}


Appendix G. Other NRC studies with multi-unit implications

\begin{tabular}{|c|c|c|c|c|c|c|}
\hline Number & Title & \multicolumn{5}{|c|}{ Description } \\
\hline & & \multicolumn{5}{|c|}{ Table 6-3. LOOP events (1986-2004) that affected more than one plant at a site. } \\
\hline & & Site & Date & $\begin{array}{l}\text { Number of } \\
\text { Plants at } \\
\text { Site }\end{array}$ & $\begin{array}{l}\text { Number of } \\
\text { Plants } \\
\text { Affected }\end{array}$ & LOOP Category \\
\hline & & Calvert Cliffs & $7 / 23 / 1987$ & 2 & 2 & Switchyard Centered \\
\hline & & Peach Bottom & $7 / 29 / 1988$ & 2 & 2 & Switchyard Centered \\
\hline & & Turkey Point & $8 / 24 / 1992$ & 2 & 2 & Weather Related \\
\hline & & Sequoyah & $12 / 31 / 1992$ & 2 & 2 & Switchyard Centered \\
\hline & & Brunswick & $03 / 16-17 / 1993$ & 2 & 2 & Weather Related \\
\hline & & Beaver Valley & $10 / 12 / 1993$ & 2 & 2 & Switchyard Centered \\
\hline & & Prairie Island & $6 / 29 / 1996$ & 2 & 2 & Weather Related \\
\hline & & $\begin{array}{l}\text { Fitzpatrick and } \\
\text { Nine Mile Point } 1\end{array}$ & $8 / 14 / 2003$ & 2 & 2 & Grid Related \\
\hline & & Indian Point & $8 / 14 / 2003$ & 2 & 2 & Grid Related \\
\hline & & Peach Bottom & $9 / 15 / 2003$ & 2 & 2 & Grid Related \\
\hline & & Palo Verde & $6 / 14 / 2004$ & 3 & 3 & Grid Related \\
\hline & & St. Lucie & $9 / 25 / 04$ & 2 & 2 & Weather Related \\
\hline & & \multicolumn{5}{|c|}{ a. In these cases, the plants shut down in anticipation of bad weather. The weather events subsequently resulted in } \\
\hline & & \multirow{6}{*}{\multicolumn{5}{|c|}{$\begin{array}{l}\text { The remaining events were single-plant events. Of the } 103 \text { presently operating plants, } \\
\text { there are } 28 \text { single-plant sites, } 33 \text { dual-plant sites, and three three-plant sites (Oconee, } \\
\text { Palo Verde, and Hope Creek/Salem.) However, if all plants that operated sometime during } \\
\text { 1986-2004 are included, the numbers are } 34,32 \text {, and 5, respectively. } \\
\text { Conditional probabilities of other plants at a multi-plant site experiencing a LOOP, given } \\
\text { a LOOP at the plant being analyzed, are presented in Table } 6-4 \text {. These conditional } \\
\text { probabilities range from } 6.0 \mathrm{E}-2 \text { for plant-centered LOOPs to } 8.2 \mathrm{E}-1 \text { for grid-related } \\
\text { LOOPs. Because all of the } 12 \text { events listed in Table } 6-3 \text { affected all plants at a site, the } \\
\text { probabilities listed in Table } 6-4 \text { are considered to apply to all other plants at the site. For } \\
\text { example, if a site has three plants and one plant experiences a grid-related LOOP while at } \\
\text { power, then the probability that the other two plants also experience the same grid-related } \\
\text { LOOP is } 8.2 \mathrm{E}-1 \text {. } \\
\text { Also presented are the composite conditional probabilities for critical operation and } \\
\text { shutdown operation. These composite conditional probabilities apply if the risk model } \\
\text { does not distinguish the individual LOOP categories. For critical operation, the composite } \\
\text { conditional probability is } 5.8 \mathrm{E}-1 \text {, while for shutdown operation the probability is } 3.0 \mathrm{E}-1 \text {. } \\
\text { C-3. ANALYSIS OF LOOP-RELATED PROBABILITIES } \\
\text { P[LOOP at other units] = count of events with LOOPs at all units / count of events with } \\
\text { LOOPs at } \\
\text { the unit under study. } \\
\text { Therefore, the set of events that form the denominator for an estimate of this probability is } \\
\text { smaller than the total set of events at multiple-unit sites. More specifically, half of the } \\
\text { single-unit LOOPs at two unit sites are relevant, one-third of the single-unit events at } \\
\text { three-unit sites are relevant, and two-thirds of the two-unit events at three-unit sites are }\end{array}$}} \\
\hline & & & & & & \\
\hline & & & & & & \\
\hline & & & & & & \\
\hline & & & & & & \\
\hline & & & & & & \\
\hline
\end{tabular}




\section{Appendix G. Other NRC studies with multi-unit implications}

\begin{tabular}{|c|c|c|c|c|}
\hline \multirow[t]{9}{*}{ Number } & \multirow[t]{9}{*}{ Title } & \multicolumn{3}{|c|}{ Description } \\
\hline & & \multicolumn{3}{|c|}{$\begin{array}{l}\text { relevant (if there were any). Of course, all the events that affected all units at a site are } \\
\text { relevant for the denominator. For an estimate of the failure probability, i.e. that no unit is } \\
\text { available to help the particular unit under consideration, the numerator is the number of } \\
\text { instances where all units at the site experienced a LOOP. Overall, the numerator is } 12 \\
\text { events. Table C }-17 \text { summarizes the calculation for the denominator. The estimate of the } \\
\text { overall probability of no unit being able to provide offsite power for the unit being } \\
\text { analyzed, using a Jeffrey's prior, is } 0.323 \text {. } \\
\text { Table C-17. Counts of events at multi-unit sites with a LOOP at a specified, particular }\end{array}$} \\
\hline & & & 2-unit sites & 3-unit sites \\
\hline & & Number of single-unit events & $46 / 2=23$ & $8 / 3=2.667$ \\
\hline & & Number of 2-unit events & 11 & $2 / 3 * 0=0$ \\
\hline & & Number of 3-unit events & - & 1 \\
\hline & & Total number of relevant site-level events & 34 & 3.667 \\
\hline & & \multicolumn{3}{|c|}{$\begin{array}{l}\text { Note: The sum of the shaded numbers is the number of relevant events that contribute to the no } \\
\text { estimated probability that no other unit at the site will have offsite power available. The grand } \\
\text { number of demands, in the denominator. }\end{array}$} \\
\hline & & \multicolumn{3}{|c|}{$\begin{array}{l}\text { The events were considered as a function of LOOP category. The hypothesis tests } \\
\text { discussed above, showing that two- and three-unit sites can be combined, give the same } \\
\text { statistical conclusions when LOOP category subsets of the data are considered. However, } \\
\text { highly statistically significant differences exist between LOOP categories (p-value = } \\
1.6 \mathrm{E}-5 \text { ). Table C-18 is an expansion of Table C-17 at a LOOP category level. The } \\
\text { shaded cells represent failures, where no other unit with offsite power was available. The } \\
\text { grand totals in each section are the demands. Note that noninteger demands can be } \\
\text { processed using the beta-binomial techniques discussed in Appendix B for processing } \\
\text { probability estimates. }\end{array}$} \\
\hline
\end{tabular}


Appendix G. Other NRC studies with multi-unit implications

\begin{tabular}{|c|c|c|c|c|}
\hline \multirow[t]{23}{*}{ Number } & \multirow[t]{23}{*}{ Title } & \multicolumn{3}{|c|}{\begin{tabular}{|c|} 
Description \\
\end{tabular}} \\
\hline & & \multicolumn{3}{|c|}{$\begin{array}{l}\text { Table } \mathrm{C}-18 \text {. Counts of events at multi-unit sites with a LOOP at a specified, particu } \\
\text { category. }\end{array}$} \\
\hline & & & 2-unit sites & 3-unit sites \\
\hline & & \multicolumn{3}{|l|}{ Plant-centered LOOPs } \\
\hline & & Number of single-unit events & 6 & 1.333 \\
\hline & & Number of 2-unit events & 0 & 0 \\
\hline & & Number of 3-unit events & 0 & 0 \\
\hline & & Total number of relevant site-level events & 6 & 1.333 \\
\hline & & \multicolumn{3}{|l|}{ Switchyard-centered LOOPs } \\
\hline & & Number of single-unit events & 15 & 1.333 \\
\hline & & Number of 2-unit events & 4 & 0 \\
\hline & & Number of 3-unit events & 0 & 0 \\
\hline & & Total number of relevant site-level events & 19 & 1.333 \\
\hline & & \multicolumn{3}{|l|}{ Grid-related LOOPs } \\
\hline & & Number of single-unit events & 0.5 & 0 \\
\hline & & Number of 2-unit events & 3 & 0 \\
\hline & & Number of 3-unit events & 0 & 1 \\
\hline & & Total number of relevant site-level events & 3.5 & 1 \\
\hline & & \multicolumn{3}{|l|}{ Weather-related LOOPs } \\
\hline & & Number of single-unit events & 1.5 & 0 \\
\hline & & Number of 2-unit events & 4 & 0 \\
\hline & & Number of 3-unit events & 0 & 0 \\
\hline & & Total number of relevant site-level events & 5.5 & 0 \\
\hline
\end{tabular}

Note: The sum of the shaded numbers is the number of relevant events that contribute to the estimated probability that no other unit at the site will have offsite power available. The gras total number of demands, in the denominator.

Table $\mathrm{C}-19$ summarizes the relevant data from Table $\mathrm{C}-17$ and Table $\mathrm{C}-18$. It provides CNID-based estimates of the failure probability from the overall data and the data for each class. Each row is a separate fitting of the beta CNID distribution constrained to have a mean equal to the number of events affecting all sites, plus 0.5 , divided by the number of relevant site events. The CNID distribution was chosen to reflect the uncertainty associated with a small data set. The higher probabilities associated with grid- and weather-related events are not surprising.

Table $\mathrm{C}-19$. Probability that the remaining units at a multiple-unit site have a LOOF particular unit.

\begin{tabular}{|c|c|c|c|c|c|}
\hline & & $\#$ of site events & & Beta dist & bution ( \\
\hline $\begin{array}{c}\text { LOOP } \\
\text { Category }\end{array}$ & $\begin{array}{c}\text { site events at } \\
\text { multiple-unit } \\
\text { sites }\end{array}$ & $\begin{array}{l}\text { uffecting all } \\
\text { the units }\end{array}$ & $\begin{array}{c}5^{\text {th }} \\
\text { percentile }\end{array}$ & Mean & $\begin{array}{r}95^{\text {th }} \\
\text { percen }\end{array}$ \\
\hline All & 37.667 & 12 & $4.34 \mathrm{E}-04$ & $3.23 \mathrm{E}-01$ & $9.37 \mathrm{E}-$ \\
\hline Plant-centered & 7.333 & 0 & $6.71 \mathrm{E}-05$ & $6.00 \mathrm{E}-02$ & $2.43 \mathrm{E}^{-}$ \\
\hline Switchyard-centered & 20.333 & 4 & $8.00 \mathrm{E}-05$ & $2.11 \mathrm{E}-01$ & $7.80 \mathrm{E}-$ \\
\hline Grid-related & 4.5 & 4 & $2.92 \mathrm{E}-01$ & $8.18 \mathrm{E}-01$ & $1.00 \mathrm{E}-$ \\
\hline Weather-related & 5.5 & 4 & $7.55 \mathrm{E}-02$ & $6.92 \mathrm{E}-01$ & $1.00 \mathrm{E}-$ \\
\hline
\end{tabular}


APPENDIX H. INTERNATIONAL STUDIES RELATED TO MULTIUNIT INITIATING EVENTS 

Appendix H. International Studies Related to Multi-Unit IEs

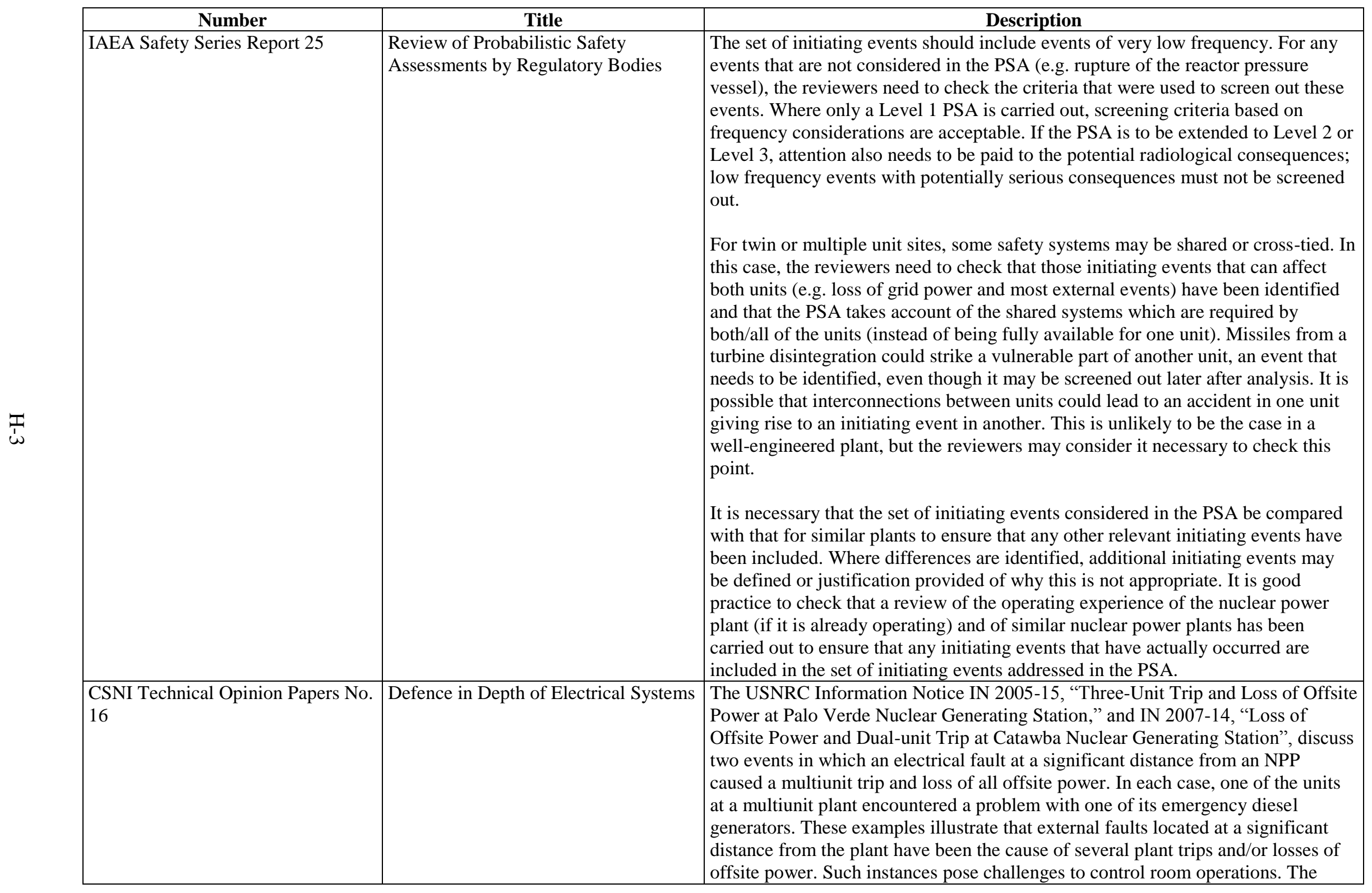


Appendix H. International Studies Related to Multi-Unit IEs

\begin{tabular}{|l|l|l|}
\hline Number & \multicolumn{1}{|c|}{ Title } & \multicolumn{1}{|c|}{ Description } \\
\hline & $\begin{array}{l}\text { lubstation serving the NPP has a significant influence in plant trips and the } \\
\text { availability of offsite power. While a plant trip may accrue a significant loss of } \\
\text { revenue, the loss of offsite power has far more significant nuclear safety } \\
\text { implications because the plants rely on offsite power as the preferred source of } \\
\text { power for emergency core cooling. }\end{array}$ \\
\hline
\end{tabular}

